
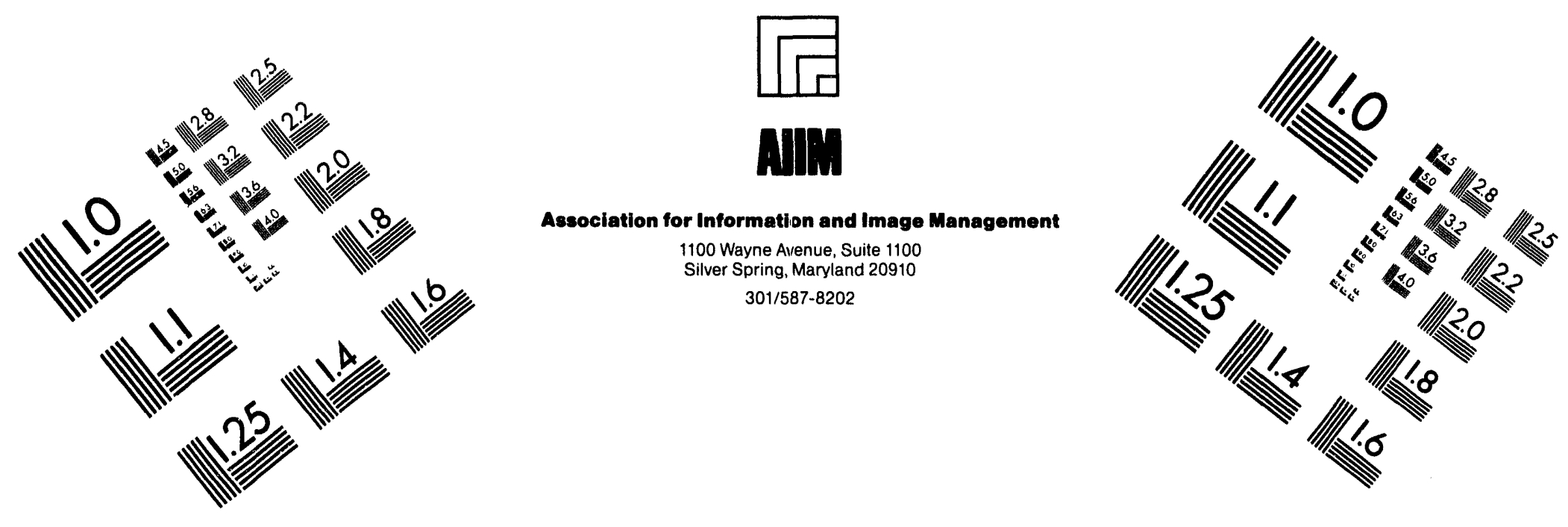

Centimeter

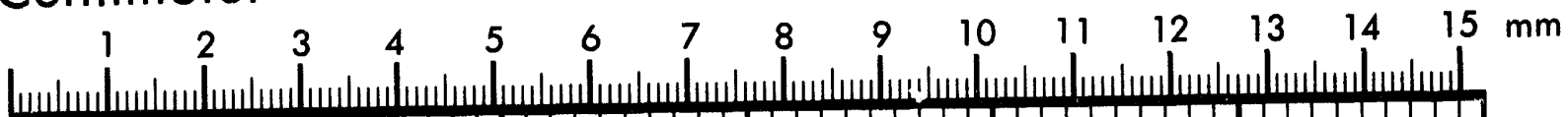

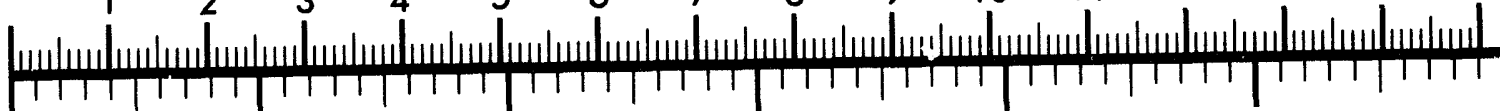

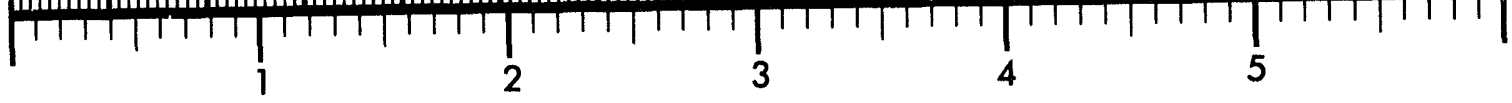
Inches
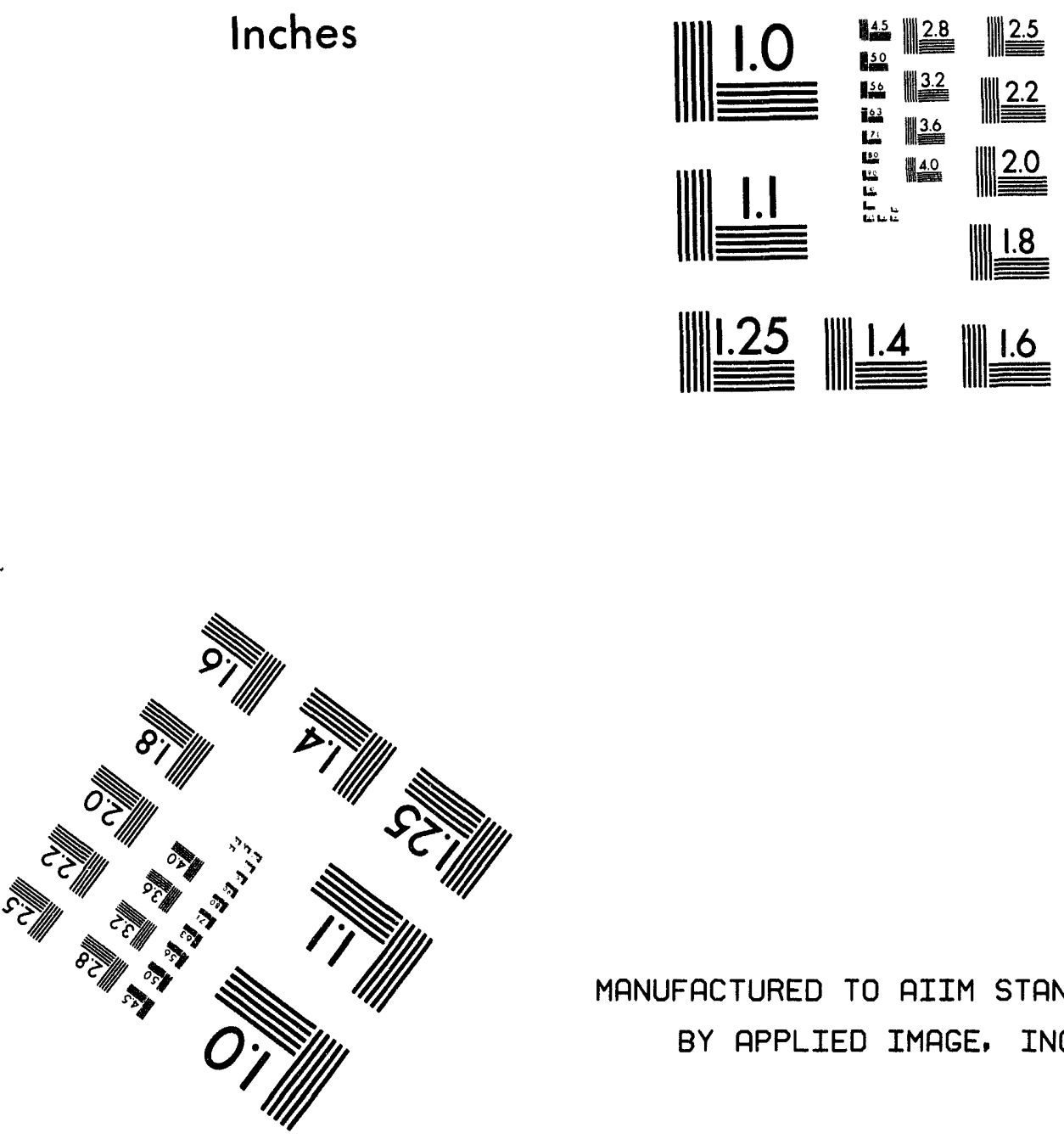

MANUFACTURED TO AIIM STANDARDS

BY APPLIED IMAGE, INC.

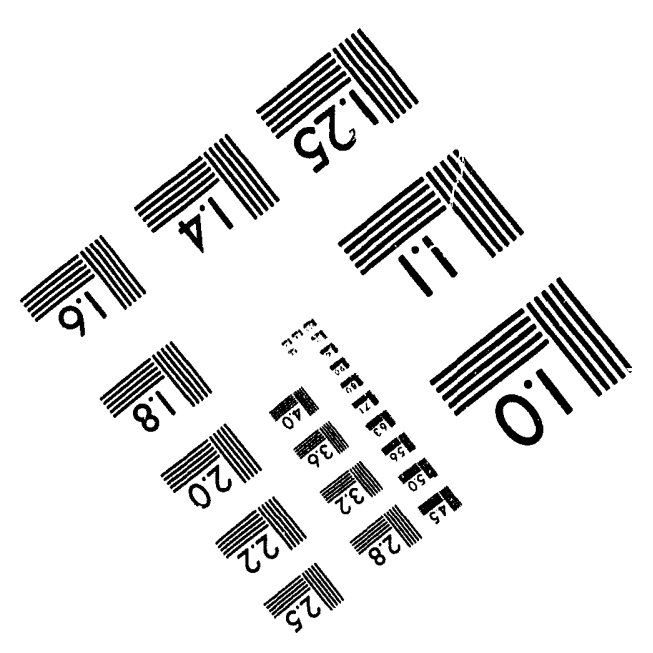



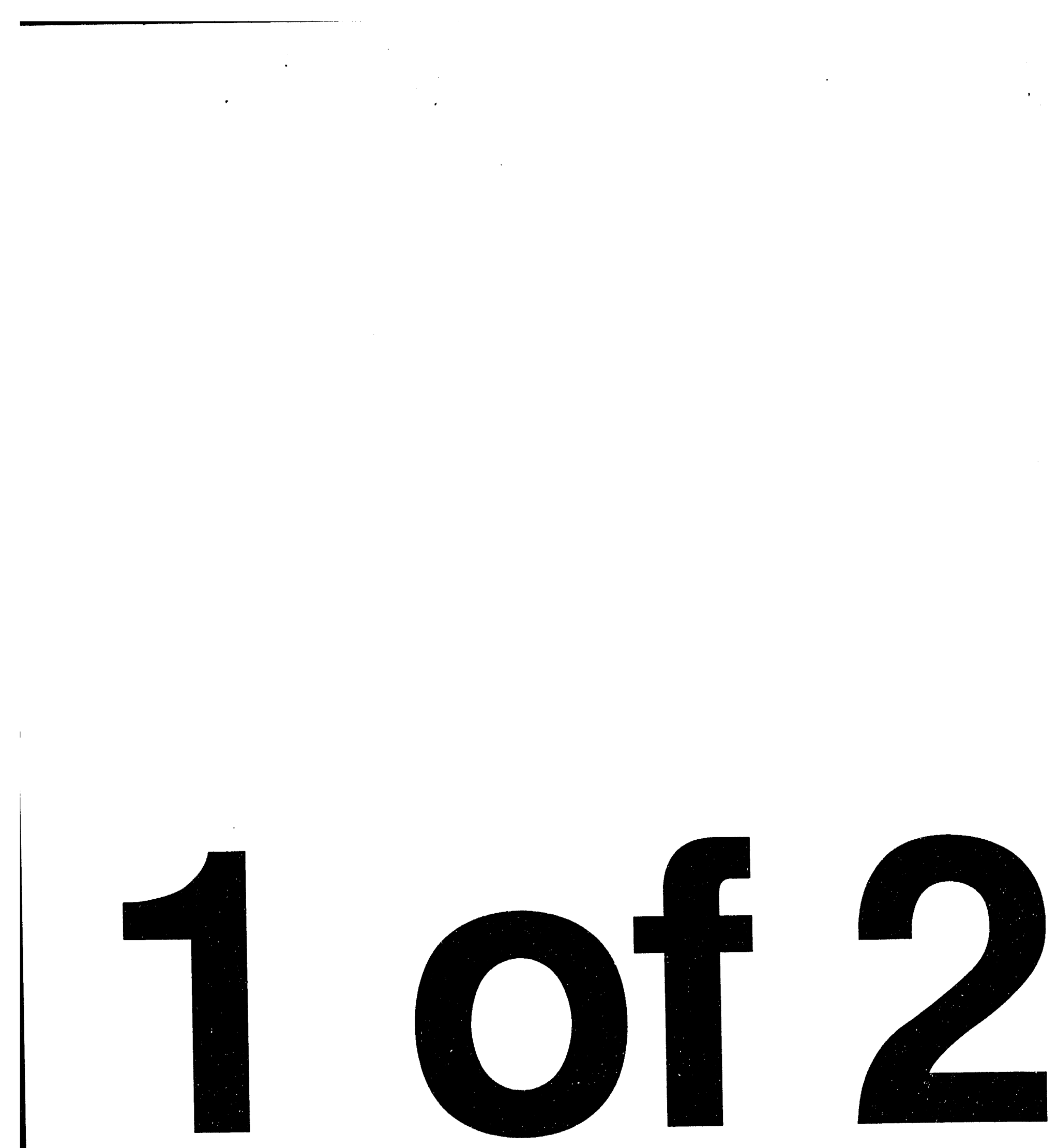
PNL-9980

UC-603

\section{Chernobyl Nuclear Accident Hydrologic Analysis and Emergency Evaluation of Radionuclide Distributions in the Dnieper River, Ukraine, During the 1993 Summer Flood}

O. V. Voitsekhovitch (a)

M. J. Zheleznyak ${ }^{(\mathbf{b})}$

Y. Onishi

June 1994

Prepared for

the U.S. Department of Energy

under Contract DE-ACO6-76RLO 1830

Pacific Northwest Laboratory

Richland, Washington 99352

(a) Ukrainian Hydrometeorological Institute (Kiev, Ukraine).

(b) Cybernetics Center of the Ukrainian Academy of Sciences (Kiev, Ukraine).

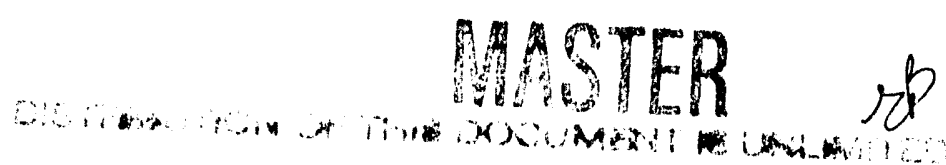




\section{Summary}

This report describes joint activities of Program 7.1.F, "Radionuclide Transport in Water and Soil Systems," of the USA/Commonwealth of Independent States (CIS) Joint Coordinating Committee of Civilian Nuclear Reactor Safety to study the hydrogeochemical behavior of radionuclides released to the Pripyat and Dnieper rivers from the Chernobyl Nuclear Power Plant in Ukraine. These joint activities included rapid evaluation of radionuclide distributions in the Pripyat and Dnieper river system and field data evaluation and modeling for the 1993 summer flood to assist the Ukrainian government in their emergency response during the flood.

About 19 million people in Ukraine consume water from the Dnieper River between Kiev and the Black Sea and thus are exposed to the impacts of the radionuclides in the river through drinking water, irrigation, and fishing; 8 million consume Dnieper River water as their drinking water. With the most current water use information available, a collective effective equivalent dose (EED) of internal exposure to the population and expected risks due to different water usage was calculated. We estimated that during 1986-1992, the collective dose (EED) for 19 million people resulting from 8 million people drinking the Dnieper River water and 19 million people consuming fish or irrigated food products are 216,100, and 513 menSv, respectively, for a total of 829 menSv. The irrigation pathway is clearly the dominant pathway among these aquatic pathways. The total aquatic pathway contribution constitutes about $7.0 \%$ of the total collective EED of 11,832 menSv from all pathways. The equivalent radiation risks from the aquatic pathway for the 19 million people are $3.2 \times 10^{-6}$, as compared to $4.5 \times 10^{-5}$ for all pathways. The expected human cancer effects from drinking the Dnieper River water and consuming radioactively contaminated fish and irrigated food products are estimated as 16,7 , and 38 people with cancers, for a total of 61 people in the total population of 19 million. The total number of people who will get cancers due to all pathways is expected to be 864 .

Even though the aquatic pathway contributes only $7 \%$ of the total dose from all the pathways, radionuclide migration into and within the rivers is important for determining potential dose to people through aquatic pathways. This is mainly because most of the practical current and future remediation will be confined to within a $30-\mathrm{km}$ zone around Chernobyl to control and reduce potential radionuclide 
migration in the aquatic (surfa :e and groundwater) pathways. The field data evaluation and modeling revealed that flooding is a critical factor that increases radionuclide concentrations in the rivers. The Pripyat River floodplain directly across from the Chernobyl Nuclear Power Plant is especially important because it received a significant amount of ${ }^{137} \mathrm{Cs}$ and ${ }^{90} \mathrm{Sr}$ deposition, with ${ }^{90} \mathrm{Sr}$ concentrations reaching $1000 \mu \mathrm{Ci} / \mathrm{m}^{2}$, accounting for approximately half of all ${ }^{90} \mathrm{Sr}$ entering the Pripyat River. During a January 1991 flood caused by an ice jam, the ${ }^{90} \mathrm{Sr}$ concentrations reached $250-300 \mathrm{pCi} / \mathrm{L}$ at Yanov Eridge (at the downstream end of the floodplain, exceeding the local drinking water limit of $100 \mathrm{pCi} / \mathrm{L}$ ). The search for effective countermeasures led to the construction of an earthen dike in 1991. The construction of a 10-km dike in the floodplain across from the Chernobyl Nuclear Plant has proved to be effective for reducing ${ }^{90} \mathrm{Sr}$ concentrations in the Pripyat River. However, despite construction of the dike, radionuclide migration and interaction between the floodplain and the Pripyat River are a long-term problem. Surface and groundwater interaction must be assessed in the future.

Despite these remediation measures, the problem of increasing of $90 \mathrm{Sr}$ concentrations in the Pripyat and Dnieper rivers during high floods still remains. In July-August 1993, heavy rainfall over the Pripyat River catchment in Belarus and Ukraine caused severe flooding, significantly raising ${ }^{90} \mathrm{Sr}$ concentrations in the river. Because of heightened public concern about radionuclide levels in the river and the need of the Ukrainian government to make an emergency response, we conducted an emergency evaluation of radionuclide distributions in the Dnieper River, while the flooding was occurring. Near the Chernobyl area, the maximum ${ }^{90} \mathrm{Sr}$ concentration in the Pripyat River reached $20-25 \mathrm{pCi} / \mathrm{L}$ in early August; near the Pripyat River mouth, the concentration rose to $35 \mathrm{pCi} / \mathrm{L}$. The peak ${ }^{90} \mathrm{Sr}$ concentration in the Kiev Reservoir (a major source of drinking water for Kiev) was $12 \mathrm{pCi} / \mathrm{L}$. The evaluations showed that if the $10-\mathrm{km}$ dike had not been constructed, ${ }^{90} \mathrm{Sr}$ concentrations in the Pripyat River, and thus also in the Dnieper River, would have been much higher. Based on these measured radionuclide levels, additional modeling results and the assumption of water purification in a water treatment station, ${ }^{90} \mathrm{Sr}$ concentrations in Kiev's drinking water were estimated to be less than $8 \mathrm{pCi} / \mathrm{L}$. Unlike ${ }^{0} \mathrm{Sr},{ }^{137} \mathrm{Cs}$ concentrations in the .ipyat River during the flood did not rise significantl' $\%$ from the pre-flood levels. Estimated ${ }^{137} \mathrm{Cs}$ concentrations for the Kiev drinking water were two orders of magnitude lower than the drinking water standard of $500 \mathrm{pCi} / \mathrm{L}$ for ${ }^{137} \mathrm{Cs}$. Thus the water was determined to be safe for Kiev's citizens to drink during the 1993 summer flood. 


\section{Acknowledgments}

This study has been founded by U.S. Department of Energy, Office of Environment, Safety and Health under Contract DE-AC06-76RLO 1830 as a part of the USA/CIS Joint Coordinating Committee on Civilian Nuclear Reactor Safety. Partial financial and logistical supports for CIS scientists to work at PNL were also provided by the U.S. Department of Commerce's Special American Business Internship Training Program. 


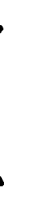




\section{Contents}

Summary $\ldots \ldots \ldots \ldots \ldots \ldots \ldots \ldots \ldots \ldots \ldots \ldots \ldots \ldots \ldots \ldots \ldots \ldots \ldots$ iii

Acknowledgments $\ldots \ldots \ldots \ldots \ldots \ldots \ldots \ldots \ldots \ldots \ldots \ldots \ldots \ldots$ vii

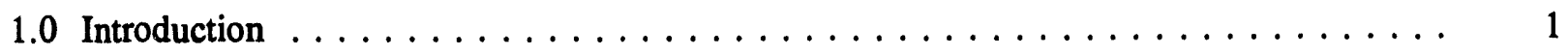

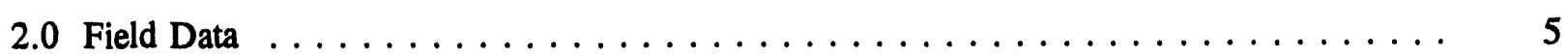

2.1 Data Collected Prior to the 1993 Summer Flood $\ldots \ldots \ldots \ldots \ldots$

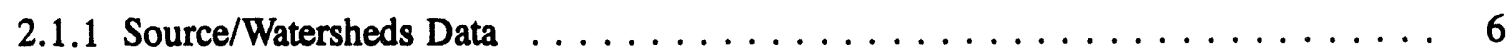

2.1 .2 River/Reservoir Hydrological Data . . . . . . . . . . . . . . . . 15

2.1.3 River/Reservoir Data - Primary Radionuclide Contamination . . . . . . . . . . . 18

2.1.4 Radionuclide Influx to the Dnieper Reservoirs . . . . . . . . . . . . . . 22

2.1.5 Radionuclide Distribution in the Dnieper Reservoirs . . . . . . . . . . . . 27

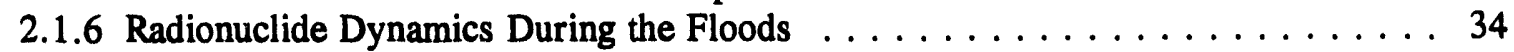

2.2 Data Collected under Summer Flood Conditions in $1993 \ldots \ldots \ldots$. . . . . . 38

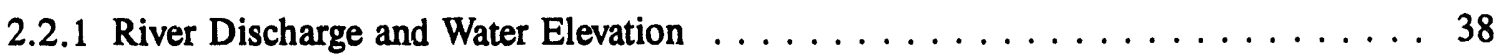

2.2.2 Radioactive Contamination of the Pripyat/Dnieper System . . . . . . . . . . . 39

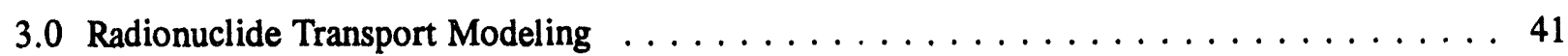

3.1 Applied Models and Methodology $\ldots \ldots \ldots \ldots \ldots \ldots \ldots \ldots \ldots \ldots \ldots$

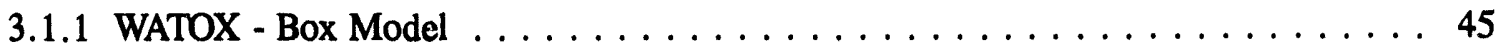

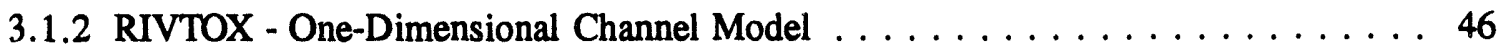

3.1.3 COASTOX - Two-Dimensional Lateral-Longitudinal Model . . . . . . . . . . . 47

3.1.4 VERTOX - Two-Dimensional Vertical-Longitudinal Model . . . . . . . . . . 47

3.2 Modeling of the Pripyat River Floodplain $\ldots \ldots \ldots \ldots \ldots \ldots$

3.3 Modeling of Dnieper River Reservoirs $\ldots \ldots \ldots \ldots \ldots \ldots \ldots$

4.0 Evaluation of the 1993 Summer Flood $\ldots \ldots \ldots \ldots \ldots \ldots$

5.0 Evaluation of Radiation Dose and Risk from Use of Dnieper River Waters $\ldots \ldots \ldots$

5.1 Characterization of Water Use on the Dnieper Reservoirs $\ldots \ldots \ldots \ldots$

5.2 Previous Estimation of Individual and Collective Long-Term Radiation Dose and Effects from Contamination of the Dnieper Aquatic Ecosystem . . . . . . . . . . . . . 69 
5.3 The Role of Different Water Uses in the Effective Equivalent

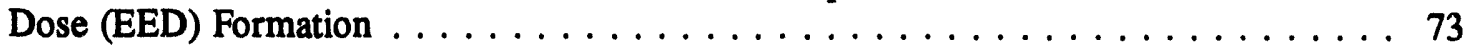

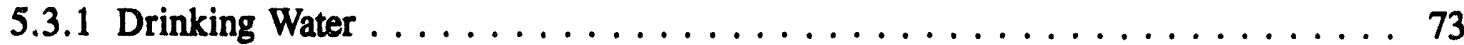

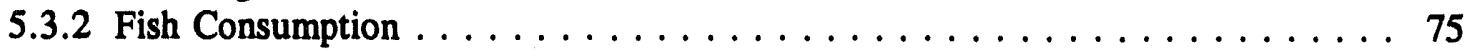

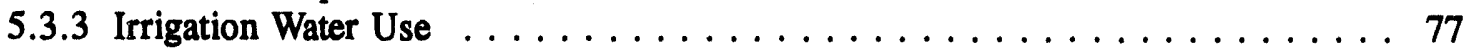

5.4 Description of Some Approaches for Radiation Risk Estimation from Dnieper Water Use . . . . . . . . . . . . . . . . . . . . . . . . 79

6.0 Summary and Conclusions $\ldots \ldots \ldots \ldots \ldots \ldots \ldots$

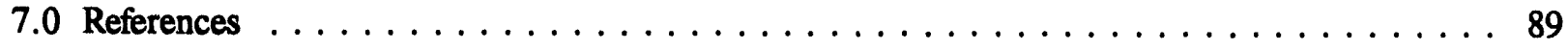

Appendix - Equations of the Box Model WATOX $\ldots \ldots \ldots \ldots \ldots \ldots \ldots \ldots$ 


\section{Figures}

$1{ }^{137} \mathrm{Cs}$ Contamination of the Catchment Areas of the Pripyat and the Upper Dnieper $\ldots \ldots \quad 2$

2 Watersheds of Small Rivers Inside the Chernobyl $30-\mathrm{km}$ Zone and Nearby Area $\ldots \ldots$

3 Map of the Pripyat-Dnieper System $\ldots \ldots \ldots \ldots \ldots \ldots \ldots$

4 Trends of ${ }^{90} \mathrm{Sr}$ and ${ }^{137} \mathrm{Cs}$ Physical-Chemical Forms Transformation in the Floodplain Soils of the Pripyat River Near the Chernobyl Nuclear Power Plant $\ldots \ldots \ldots \ldots \ldots \ldots$

$5{ }^{137} \mathrm{Cs}$ Distribution on the Suspended Particles of the Pripyat River near the Town

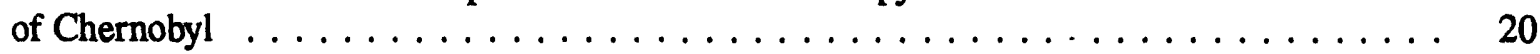

$6{ }^{137} \mathrm{Cs}$ Distribution on the Suspended Particles of the Pripyat River near the Chernobyl Nuclear Power Plant . . . . . . . . . . . . . . . . . . . . . . . . 21

7 Time Variations of Water Discharge and of ${ }^{137} \mathrm{Cs}$ and ${ }^{90} \mathrm{Sr}$ Concentrations (daily averaged data) after the Accident for the Pripyat River, at the Town of Chernobyl . . . . . . . . .

8 Time Variations of Water Discharge, and of ${ }^{137} \mathrm{Cs}$ and ${ }^{90} \mathrm{Sr}$ Concentrations (ten-day averaged data) and Their Ratio after the Accident for the Dnieper River at Nedanchychy . . 24

9 Radionuclide Contamination of the Kiev Reservoir after the Accident . . . . . . . . 29

10 Radioactive Contamination of the Dnieper Reservoirs After the Chernobyl Accident ${ }^{137} \mathrm{Cs}$ Concentrations in Water, ${ }^{90} \mathrm{Sr}$ Concentrations, Total ${ }^{137} \mathrm{Cs}$ in Bottom Sediment . . . .

11 Vertical Distribution of Different Physical-Chemical Forms of ${ }^{90} \mathrm{Sr}$ in the Bottom Sediments of the Kiev Reservoir, in the Upper Part of the Area of Suspended Particles Deposition,

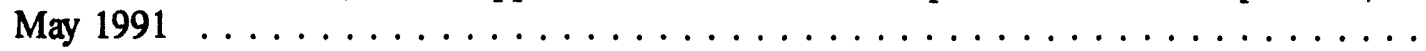

$12{ }^{90} \mathrm{Sr}$ Distribution in the Chernobyl Close-in Zone and on the Floodplain Area of the Pripyat River near the Chernobyl Nuclear Power Plant . . . . . . . . . . . . . 36

13 Predicted Depth-Averaged Velocities on the Pripyat River Floodplain During a 25\% PE Spring Flood $\ldots \ldots \ldots \ldots \ldots \ldots \ldots \ldots \ldots \ldots \ldots \ldots$

14 Predicted Depth-Averaged ${ }^{90} \mathrm{Sr}$ Concentration and Depth Isolines During a 25\% PE Spring Flood

15 Predicted Depth-Averaged Velocities During the Same Flood as Presented in Figure 13 after Construction of the Dike 
16 Predicted Depth-Averaged ${ }^{90} \mathrm{Sr}$ Concentration During the Same Flood as Presented in Figure 13 after Construction of the Dike . . . . . . . . . . . . . . . . 52

$17{ }^{90} \mathrm{Sr}$ Concentrations Near Kiev Hydropower Plant Since January $1,1991 \ldots \ldots \ldots$

18 Predicted ${ }^{137}$ Cs Concentrations in the Dnieper Reservoirs During the 1988 Spring Flood. Predicted and Measured data $\ldots \ldots \ldots \ldots \ldots \ldots \ldots \ldots \ldots \ldots \ldots$

19 Simulated ${ }^{90} \mathrm{Sr}$ Concentrations in the Dnieper Reservoirs During a 25\% PE Spring Flood before and after Construction of the Dike $\ldots \ldots \ldots \ldots \ldots \ldots \ldots \ldots$

$20{ }^{90} \mathrm{Sr}$ Concentration in the Pripyat River and the Dnieper Reservoirs During

$21{ }^{90} \mathrm{Sr}$ Concentration in the Pripyat River and the Dnieper Reservoirs for Scenario of the Pripyat Floodplain Flooding . 


\section{Tables}

1 Amounts of ${ }^{137} \mathrm{Cs}$ and ${ }^{90} \mathrm{Sr}$ in the Catchment Areas of the Main Rivers and Tributaries . . . 3

2 Radionuclide Content in Catchments of 30-km Zone of the Chernobyl Nuclear

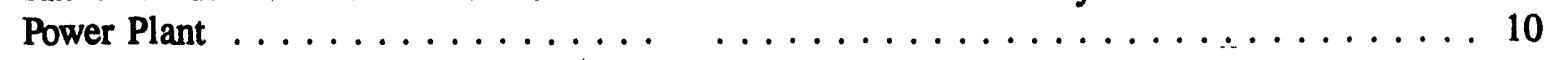

3 Liquid Washoff Coefficients for ${ }^{137} \mathrm{Cs}$ and ${ }^{90} \mathrm{Sr}$, Obtained at Experimental Sites in the $30-\mathrm{km}$ Zone around the Chernobyl Nuclear Power Plant $\ldots \ldots \ldots \ldots \ldots$

4 Time Variation of Mobile Chemical Form in the Floodplain Soil of Nearest Zone Around the Chernobyl Nuclear Power Plant $\ldots \ldots \ldots \ldots \ldots \ldots \ldots \ldots \ldots \ldots \ldots \ldots \ldots \ldots \ldots$

5 Surface-Water Elevation of the Pripyat River Across the 30-km Zone of Chernobyl During Spring Floods with Different Probabilities of Water Discharges $\ldots \ldots \ldots \ldots$

6 Main Hydrological Data for Dnieper Reservoirs $\ldots \ldots \ldots \ldots \ldots$

7 Annual Dnieper and Pripyat Rivers Radionuclide Flux and Washout Coefficients from Their Catchment During the Period after the Accident $\ldots \ldots \ldots \ldots \ldots$

8 Distributions of Suspended Sediments and their Associated Radionuclides along

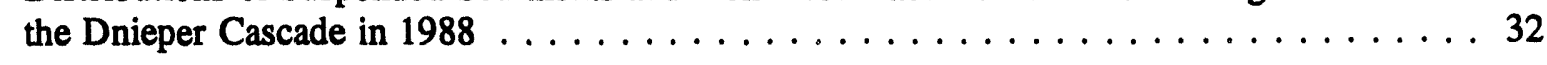

9 Averaged ${ }^{137} \mathrm{Cs}$ Contamination in Bottom Sediments of the Kiev, Kanev, Krementchug, and Kakhov Reservoirs in 1987 and $1991 \ldots \ldots \ldots \ldots \ldots \ldots \ldots \ldots \ldots \ldots \ldots \ldots \ldots \ldots$

10 Water Discharge and ${ }^{90} \mathrm{Sr}$ and ${ }^{136} \mathrm{Cs}$ Contents $\ldots \ldots \ldots \ldots \ldots \ldots$

11 Dnieper Water $U$ ige for Municipal Drinking Water System $\ldots \ldots \ldots \ldots$

12 Fish Commercial Catch in Dnieper Reservoirs During 1983-1990, in Tons . . . . . . . 68

13 Volumes of Dnieper's Water Consumption for Irrigation in Different Regions of Ukraine . . 69

14 Specific Activity of Radionuclides in the Rice Crop, Bq/kg (by Prister et al. 1992) . . . . . 70

15 Specific Activity of ${ }^{137} \mathrm{Cs}$ in Products Obtained from the Irrigated Lands in 1988, Bq/kg . . 70

16 Estimation of ${ }^{137} \mathrm{Cs}$ Concentration in Different Fish Species Caught from the Kiev

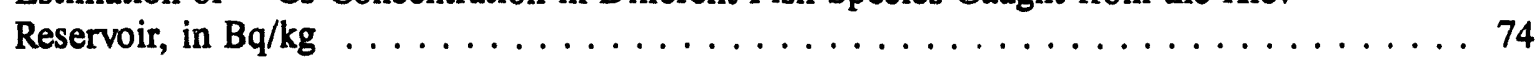

17 Increment of Collective Effected Equivalent Dose of Internal Exposure to Population Living Along the Dnieper Reservoirs and Expected Risks Due to Different Water Usage

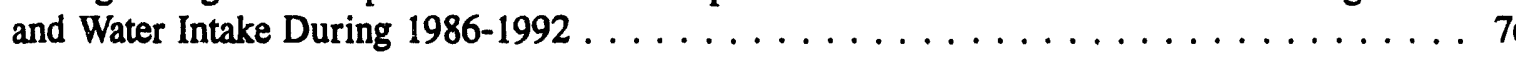




\subsection{Introduction}

Within the framework of the activities of Program 7.1.F "Radionuclide Transport in Water and Soil Systems" of the USA/Commonwealth of Independent State (CIS) Joint Coordinating Committee on Civilian Nuclear Reactor Safety, a USA/CIS working group has been studying the behavior of radionuclides in soil and water contaminated by the 1986 Chernobyl Nuclear Power Plant accident (Onishi et al. 1993). This document has been prepared during the group members' joint work at the Pacific Northwest Laboratory (PNL). ${ }^{(a)}$

The Dnieper Piver watershed in Ukraine, Russia, and Belarus was heavily contaminated by radionuclides accidentally released from Reactor Unit No. 4 of the Chernobyl Nuclear Power Plant in Ukraine on April 26, 1986. During the accident, approximately $4 \%$ of the fission products and activates in Reactor Unit No. 4 were released to the atmosphere (Izrael et al. 1987; Izrael 1988). A significant portion of the radionuclides released fell onto the watershed of the Pripyat River in Ukraine and Belarus. The Chernobyl Nuclear Power Plant is located along the west bank of the Pripyat River approximately $30 \mathrm{~km}$ from its mouth at the Kiev Reservoir on the Dnieper River. Other areas that were heavily contarninated by ${ }^{137} \mathrm{Cs}$ are in the upper Dnieper watershed in Russia and Belarus (Figure 1 and Table 1). As a result of this surface contamination, there is a long-term influx of ${ }^{137} \mathrm{Cs}$ and ${ }^{90} \mathrm{Sr}$ into the Dnieper River, which passes through six reservoirs before discharging into the Black Sea. There has also been a significant increase in ${ }^{90} \mathrm{Sr}$ concentration in the Kiev Reservoir (reaching

(a) Pacific Northwest Laboratory is operated for the U.S. Department of Energy by Battelle Memorial Institute under Contract DE-AC06-76RLO 1830. 


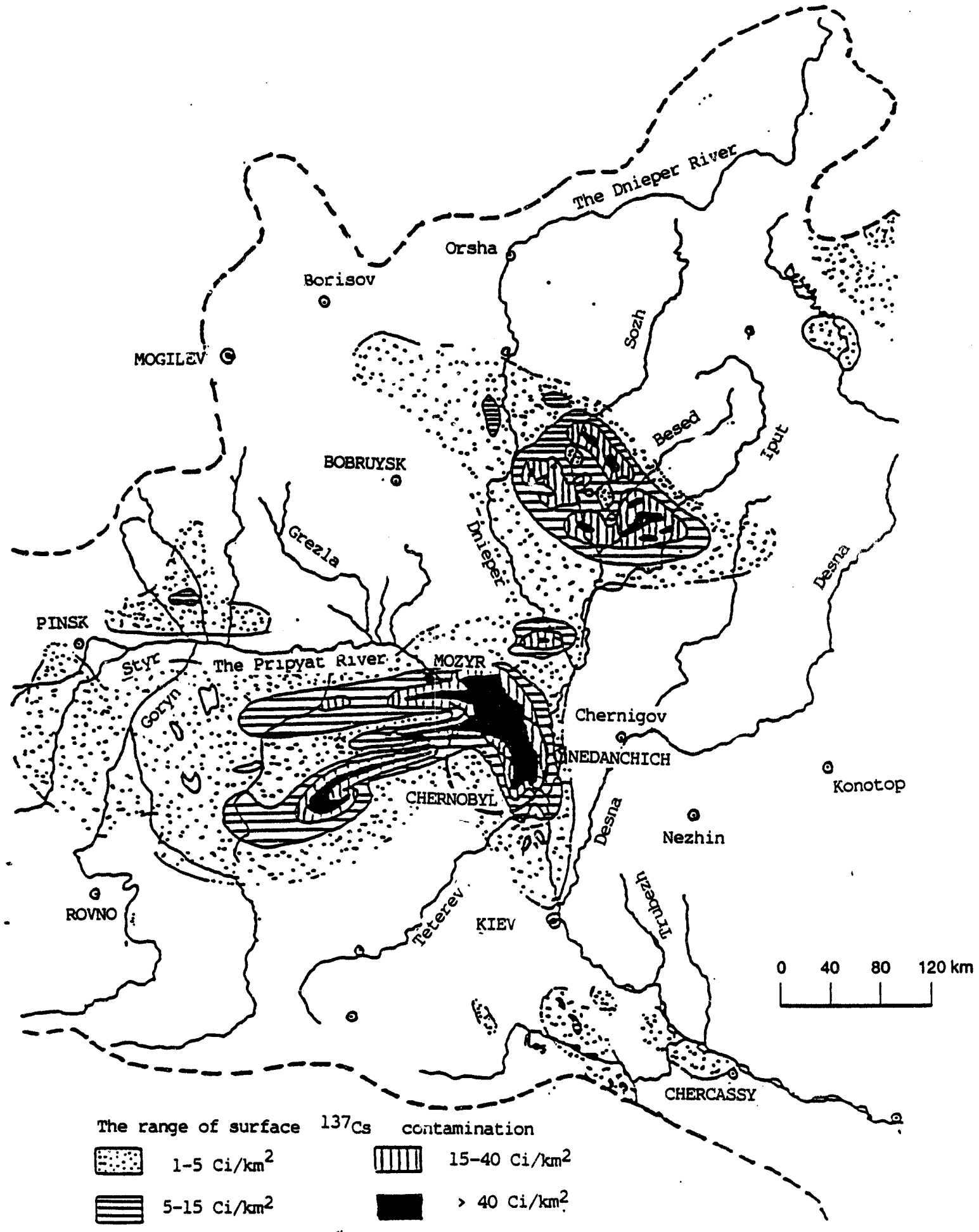

Figure 1. ${ }^{137} \mathrm{Cs}$ Contamination of the Catchment Areas of the Pripyat and the Upper Dnieper River Basins 
Table 1. Amounts of ${ }^{137} \mathrm{Cs}$ and ${ }^{90} \mathrm{Sr}$ in the Catchment Areas of the Main Rivers and Tributaries Feeding the Kiev Reservoir ${ }^{(a)}$

\begin{tabular}{|l|c|c|c|c|}
\hline \multirow{2}{*}{ Watershed } & \multicolumn{3}{|c|}{ Catchment Area, $10^{3} \mathrm{~km}^{2}$} & \multicolumn{2}{|c|}{$\begin{array}{c}\text { Amounts of Radionuclides, } \\
10^{3} \mathrm{Ci}\end{array}$} \\
\cline { 2 - 5 } & Basin & $\begin{array}{c}\text { Area with } \\
\text { Radionuclide } \\
\text { Greater than } \\
1 \mathrm{Ci} / \mathrm{km}^{2}\end{array}$ & ${ }^{137} \mathrm{Cs}$ & ${ }^{90} \mathrm{Sr}$ \\
\hline Above Dnieper mouth & 105 & 29 & 275 & 6 \\
Above Pripyat mouth & 115 & 27 & 180 & 42 \\
Braginka and interfluve & 2 & 2 & 55 & 12 \\
Above Desna mouth & 89 & 61 & 8 & $<1$ \\
\hline $\begin{array}{l}\text { (a) The radioactive contamination of the Chernobyl Nuclear Power Plant site was } \\
\text { not taken into account when evaluating the radionuclide contents. }\end{array}$
\end{tabular}

more than $100 \mathrm{pCi} / \mathrm{L}$ in the northern part of the reservoir). The radionuclide influx from these distributed (non-point) source areas to the rivers has increased during each spring flood generated by snow melting (1987-1992) and during floods caused by high rainfall in the Pripyat River watershed (July 1988, October 1990). In addition, during the winter of 1991, the formation of a ice jam in the Pripyat River caused flooding of the Pripyat River floodplain near Chernobyl Nuclear Power Plant.

More than 20 million people in Ukraine consume water from the Dnieper River downstream from the Kiev Reservoir to the Black Sea, and thus are exposed to the impact of these radionuclides. The surface-water protection activities in this area have in effect been concentrated mainly on counterflooding measures (Voitsekhovitch et al. 1989; Zheleznyak and Voitsekhovitch 1991). A 10-km dike was constructed along the Pripyat R:ver in 1991 to prevent flooding of the heavily contaminated floodplain just upstream of the Chernobyl Nuclear Power Plant. 
Despite these measures, the problem of increasing of ${ }^{90} \mathrm{Sr}$ concentration in Dnieper water during high floods remains.

During July-August 1993, heavy rainstorms in the Belarus and Ukrainian districts of the Pripyat River catchment raised water levels in the upper tributaries and the main river unusually high for summer flooding. From the second week of July to late August, Pripyat River discharges increased from $250 \mathrm{~m}^{3} / \mathrm{s}$ to $1200 \mathrm{~m}^{3} / \mathrm{s}$ near Chernobyl, with an increase in ${ }^{90} \mathrm{Sr}$ concentrations in the river waters from 7-10 $\mathrm{pCi} / \mathrm{L}$ to $25-30 \mathrm{pCilL}$.

This report describes the USA/CIS working group members' joint work at PNL, emphasizing two main objectives:

1. Evaluation of radionuclide distributions in the Pripyat-Dnieper aquatic system, which was heavily contaminated by the 1986 Chernobyl nuclear accident, and associated radiation dose.

2. Emergency evaluation of the radionuclide distribution in the Dnieper River system during the 1993 summer flood to assist the Ukrainian government for their emergency response, based on group members' experience, in studies in Ukraine and the United States and based on simple mathematical modeling and available results of experimental studies. 


\subsection{Field Data}

\subsection{Data Collected Prior to the 1993 Summer Flood}

Immediately after the 1986 accident, a main monitoring system around Chernobyl was organized by the USSR State Committee on Hydrometeorology with the scientific guidance of the committee's Scientific Production Association (SPA) Typhoon (Izrael 1987; Vakulovsky et al. 1991). During the years after the accident, the monitoring system was evaluated by various Ukrainian government agencies, including the Ministry of Chernobyl Affairs, the Hydrometeorological Service of Ukraine, the Committee of Water Supply, and the Geological Service of Ukraine. The Special Monitoring Environment Safety Department of SPA Pripyat and the Ministry of Chernobyl Affairs of Ukraine were responsible for surface and groundwater monitoring, water protection activities, and emergency control of radionuclide contamination of the river and groundwater in the $30-\mathrm{km}$ area surrounding the Chernobyl Nuclear Power Plant.

The Ukrainian Hydrometeorological Institute provided the generalization of these data and the evaluation of the water monitoring system for surface-water contamination (Voitsekhovitch et al. 1990, 1991); for groundwater, the Institutes of Geological Science of the Ukrainian Academy of Sciences provided corresponding information. 


\subsubsection{Source/Watersheds Data}

The radioactive cloud caused by the Chernobyl release and the subsequent aerosol fallout caused radioactive contamination in areas to the west and north of the Chernobyl Nuclear Power Plant subjected to the meteorological conditions for air mass transfer. From April 26 to May 8, 1986, the continuing release of gaseous, volatile, and aerosol products from the plant led to the formation of what are known as the near and distant zones of radioactive fallout (see Figure 1).

Data on the daily releases into the atmosphere make it possible to determine the composition of the release and the physical and chemical properties of the radionuclides, which changed during the time that radionuclide atmospheric transport and deposition took place. For this reason, the radionuclide composition of the fallout over the territory was heterogeneous, varying with direction and distance from the Chernobyl Nuclear Power Plant.

The shock wave of the Chernobyl explosion, the temperature gradient present, and oxidation of the nuclear fuel (uranium dioxide, or $\mathrm{UO}_{2}$ ) led to the formation of "hot" fuel particles, over $90 \%$ of which had an activity on the order of $1 \mathrm{nCi}$ per particle. These "hot" fuel particles had a radionuclide composition similar to that of spent fuel. The release of "hot" fuel particles into the environment is the unique feature of contamination from the Chernobyl accident. The destruction of the fuel elements and the "annealing" of the nuclear fuel also released a considerable quantity of volatile fission products into the atmosphere, some of them condensed on the inert carrier particles of the aerosols (e.g., mixtures of dust, and construction materials). The properties of the "hot" particles formed in the accident were similar to those formed in the last stage of a nuclear explosion (Demchuk et al. 1991). 
The condensed particles (with aerosols) that formed as a result of the Chernobyl accident are similar to radionuclides of the global fallout after nuclear weapons tests, and therefore it is possible to predict their behavior in water bod: ; to a reasonable degree. However, the behavior of the fuel particles, which are a unique feature of the Chernobyl accident and are concentrated primarily within approximately $60 \mathrm{~km}$ around the Chernobyl Nuclear Power Plant, presents major scientific problems.

Most of the radioactive fallout was deposited on the catchment areas of the Pripyat, Dnieper, and Desna Rivers, which are the main rivers feeding the reservoirs in the Dnieper cascade (Figures 1, 2, and 3; Tables 1 and 2). The radioactive trail has three distinct branches (northern, western and southern), which cover the southern districts of Belarus, the western part of the Bryansk region of Russia, and the northern and central regions of Ukraine. Measurements of ${ }^{137} \mathrm{Cs}$ and ${ }^{90} \mathrm{Sr}$ in the catchment areas of the main tributaries of the Pripyat and the Dnieper rivers were provided by Vakulovsky and Voitsekhovitch (1990) and Vakulovsky et al. (1991, 1993). The accident contaminated the water bodies in two stages: first via direct radioactive fallout from atmosphere during the first weeks after the explosion, and then via the aquatic pathway as a result of various secondary radionuclide migration processes. The important feature of the data on the Chernobyl fallout is the large difference in radionuclide distributions between ${ }^{90} \mathrm{Sr}$ (which is mainly localized around the Chernobyl Nuclear Power Plant) and ${ }^{137} \mathrm{Cs}$ (which is spread over large territories outside the $30-\mathrm{km}$ zone but also localized in contaminated spots in the upper Dnieper catchment).

Study of the distribution of physical-chemical forms of the radionuclides and their transformations in the water-soil systems in the water catchments during the five years after initial fallout showed that the proportion of mobile (soluble and exchangeable) forms in aerosol fallout immediately after the accident was significantly higher for ${ }^{137} \mathrm{Cs}$ than for ${ }^{90} \mathrm{Sr}$ (Bobovnikova et al. 1990). 


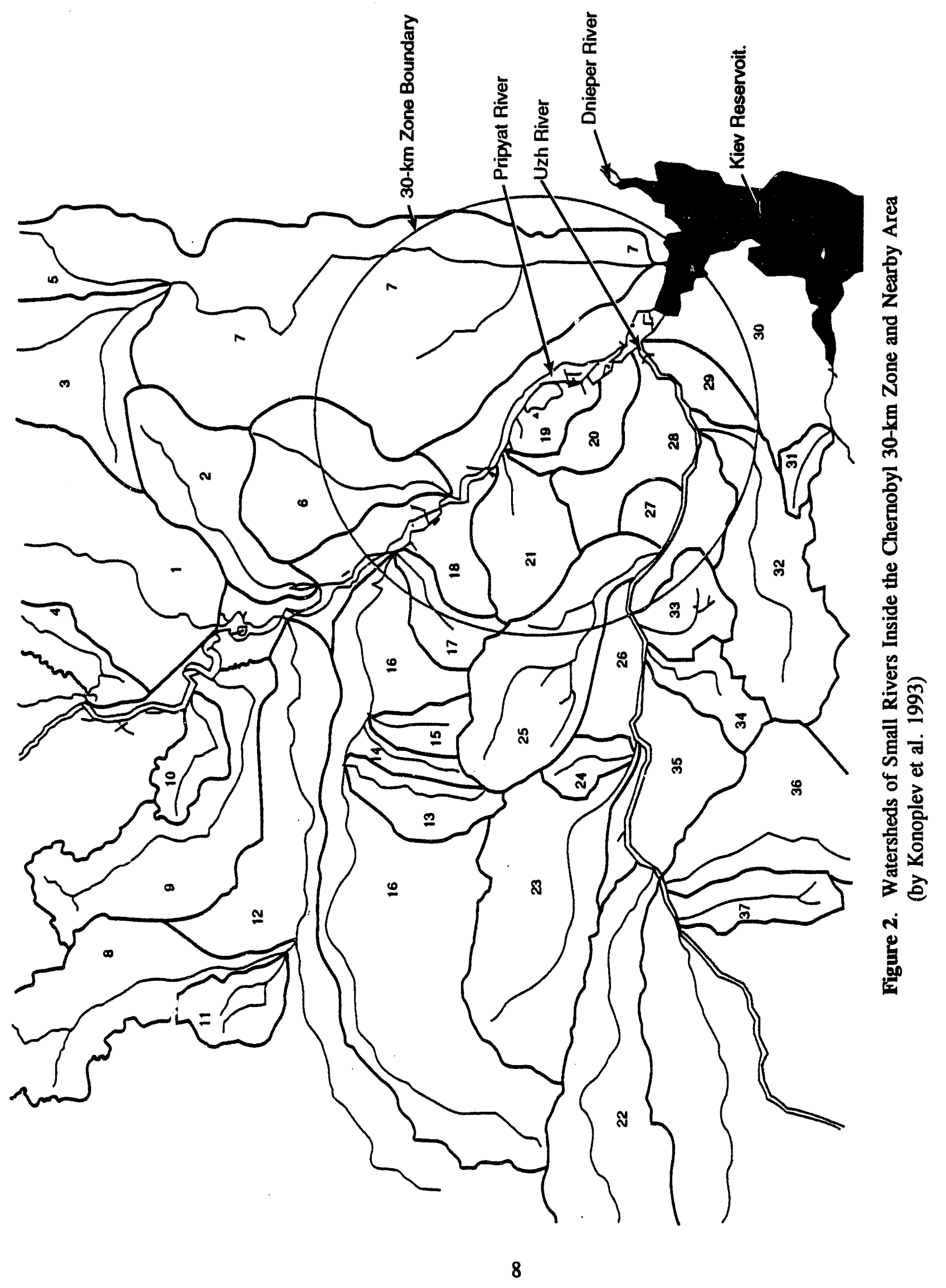




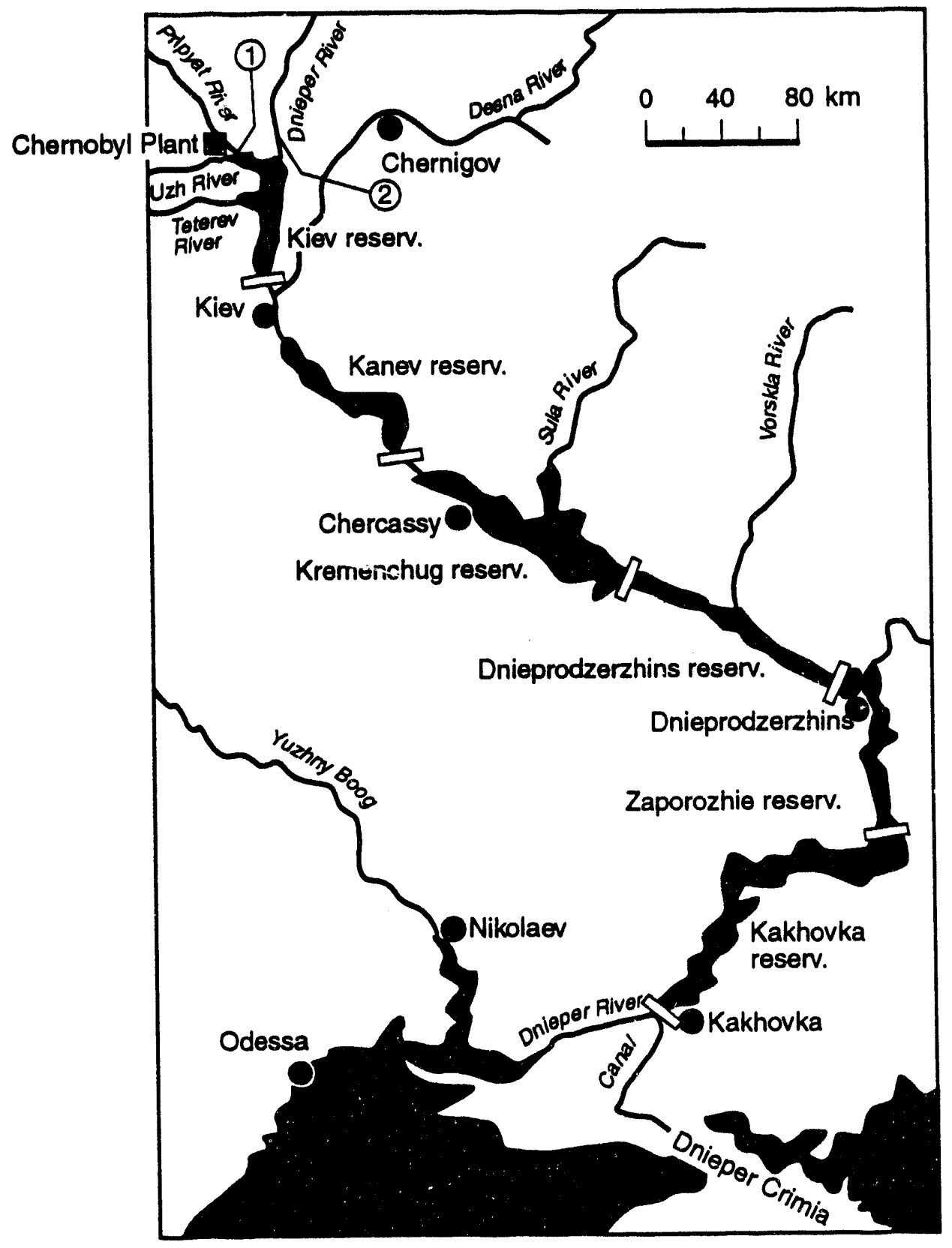

59309086.3

Figure 3. Map of the Pripyat-Dnieper System 
Table 2. Radionuclide Content in Catchments of $30-\mathrm{km}$ Zone of the Chernobyl Nuclear Power Plant

\begin{tabular}{|c|c|c|c|c|c|c|}
\hline $\begin{array}{l}\text { Catchment } \\
\text { Number }\end{array}$ & Area, $\mathrm{km}^{2}$ & $\begin{array}{c}\text { Forest } \\
\%\end{array}$ & $\begin{array}{c}\text { Swamp } \\
\%\end{array}$ & $\begin{array}{c}\text { Meadow } \\
\%\end{array}$ & $\begin{array}{c}{ }^{90} \text { Sr Amount } \\
\text { Ci }\end{array}$ & $\begin{array}{c}{ }^{137} \mathrm{Cs} \mathrm{Amount} \\
\mathrm{Ci}\end{array}$ \\
\hline 1 & 777 & 27 & 15 & 58 & 790 & 8450 \\
\hline 2 & 255 & 21 & 13 & 66 & 350 & 5320 \\
\hline 3 & 286 & 45 & 15 & 40 & 530 & 2190 \\
\hline 4 & 120 & 15 & - & - & 80 & 680 \\
\hline 5 & 37 & 60 & - & - & 650 & 140 \\
\hline 6 & 497 & 14 & 13 & 13 & 1110 & 51440 \\
\hline 7 & 1557 & 32 & 22 & 46 & 9160 & 93760 \\
\hline 8 & 420 & 70 & 20 & 10 & 340 & 2270 \\
\hline 9 & 477 & 35 & 7 & 58 & 160 & 6240 \\
\hline 10 & 102 & 26 & 25 & 49 & 80 & 1670 \\
\hline 11 & 122 & 34 & 17 & 49 & 70 & 1010 \\
\hline 12 & 302 & 35 & 0 & 65 & 350 & 4760 \\
\hline 13 & 105 & 46 & 13 & 41 & 50 & 1820 \\
\hline 14 & 60 & 54 & 11 & 35 & 10 & 1520 \\
\hline 15 & 77 & 57 & 28 & 15 & 20 & 2310 \\
\hline 16 & 1177 & 34 & 25 & 41 & 180 & 32850 \\
\hline 17 & 108 & 59 & 8 & 33 & 190 & 3360 \\
\hline 18 & 108 & 85 & 7 & 8 & 230 & 3290 \\
\hline 19 & 73 & 40 & 2 & 58 & - & - \\
\hline 20 & 104 & 33 & 0 & 67 & $2: 0$ & 6300 \\
\hline 21 & 222 & 33 & 18 & 49 & 880 & 11810 \\
\hline 22 & 777 & 30 & 12 & 58 & 350 & 4180 \\
\hline 23 & 576 & 54 & 4 & 42 & 120 & 2990 \\
\hline 24 & 65 & 45 & 39 & 16 & 20 & 420 \\
\hline 25 & 386 & 46 & 18 & 36 & 30 & 7500 \\
\hline 26 & 116 & 13 & 15 & 72 & 180 & 4120 \\
\hline 27 & 64 & 70 & 0 & 30 & 30 & 130 \\
\hline 28 & 281 & 51 & 7 & 42 & 870 & 8790 \\
\hline 29 & 86 & 90 & 5 & 5 & 180 & 490 \\
\hline 30 & 333 & 30 & 0 & 70 & 590 & 1680 \\
\hline 31 & 57 & 29 & 3 & 68 & 80 & 330 \\
\hline
\end{tabular}


As a result of mechanical destruction and dissolution of the fuel component in the fallout, ${ }^{90} \mathrm{Sr}$ and ${ }^{137}$ Cs were leached into the soil at approximately the same rate. However, because of the different fixation mechanisms between cesium and strontium in the catchment soils, radioactive contamination of the water systems differed. Although there was a decrease in the amount of ${ }^{137} \mathrm{Cs}$ in the exchangeable forn as a result of fixation with soil, the mobile physical-chemical forms of ${ }^{90} \mathrm{Sr}$ increased (Konoplev et al. 1988, 1990a,b). These processes, working together with decay and radionuclide seepage from the upper soil layer, have led to a decrease in the magnitude of effective washout for ${ }^{137} \mathrm{Cs}$ for the watersheds in areas around Chernobyl. The effective washout for ${ }^{90} \mathrm{Sr}$ has mostly stayed at about the same level during the seven years since the accident.

The first studies relating to the washout of Chernobyl radionuclides from catchment to a receiving river were carried out as early as the summer of 1986, using artificial sprinkling on specially equipped runoff sites (Borzilov et al. 1988). The critical parameter describing the land surface washout process is the washout coefficient, $\mathbf{k}_{\mathrm{w}}$, defined as the fraction of the radionuclide load in the soil which has entered the water body with the overland flow. Since a radionuclide is either in dissolved state or adsorbed on suspended particles in a solid phase, it is convenient to express the washoff coefficient as the sum of "liquid" and "solid" washout coefficients $\left(\mathrm{K}_{\mathrm{w}}=\mathrm{K}_{\mathrm{L}}+\mathrm{K}_{\mathrm{g}}\right)$. These coefficients are defined as (Konoplev et al. 1992)

$$
K_{L}=\frac{\int_{0}^{t} C_{w}(t) q(t) d t}{h \int_{s} C_{s} d s}
$$




$$
K_{s}=\frac{\int_{0}^{t} C_{a}(t) q(t) d t}{m \int_{1} C_{s} d s}
$$

where $\mathrm{Ca}=$ radionuclide concentration attached to suspended sediment in runoff water

$$
\begin{aligned}
& C w=\text { dissolved radionuclide concentration in runoff water } \\
& C s=\text { radionuclide concentration on the surface of the soil } \\
& \mathbf{h}=\text { runoff water depth } \\
& m \text { = mass of the moved suspended matter from the unit area } \\
& \mathbf{q}=\text { water discharge of the overland flow } \\
& \mathbf{s}=\text { surface area of the watershed } \\
& T=\text { duration of surface runoff }
\end{aligned}
$$

Table 3 shows the standardized washout coefficients for the main long-lived radionuclides as a result of fluvial and snow-melt runoff based on experiments at the runoff sites (Voitsekhovitch et al. 1993a). Details of the experimental studies of the liquid and erosion washout processes and supplementary information about washout parameters from the areas contaminated by Chernobyl have been described by Borzilov et al. (1988) and Konoplev et al. (1990a,b, 1992).

After radionuclides fall onto the surface of the soil, they become fixed with soil and migrate into the depths of the soil. These processes result in a reduction in the magnitude of the radionuclide washoff coefficients of surface runoff. However, there was no significant drop in the $\mathrm{K}_{\mathrm{L}}$ level for ${ }^{90} \mathrm{Sr}$ between the summer of 1986 and the autumn of 1989 . This phenomenon can be explained by the fact 
Table 3. Liquid Washoff Coefficients $\left(K_{\mathcal{L}}\right)$ for ${ }^{137} \mathrm{Cs}$ and ${ }^{90} \mathrm{Sr}$, Obtained at Experimental Sites in the $30-\mathrm{km}$ Zone around the Chernobyl Nuclear Power Plant

\begin{tabular}{|c|c|c|c|}
\hline \multirow[b]{2}{*}{ Experimental Site } & \multirow[b]{2}{*}{ Date } & \multicolumn{2}{|c|}{ Liquid Washoff Coefficients $\left(10^{-9} \mathrm{~K}_{\mathrm{L}} \mathrm{mm}^{-1}\right)$} \\
\hline & & ${ }^{137} \mathrm{Cs}$ & ${ }^{0} \mathrm{Sr}$ \\
\hline \multirow[t]{2}{*}{ Chernobyl } & Jul 988 & 1.1 & 42 \\
\hline & Jul 1089 & 1.0 & 45 \\
\hline \multirow[t]{6}{*}{ Benevka } & Oct 1486 & 0.6 & 5.8 \\
\hline & Mar 87 & 0.2 & 0.6 \\
\hline & Sep 1787 & 0.3 & 21 \\
\hline & Jul 888 & 1.0 & 20 \\
\hline & Jul 1188 & 0.7 & 13 \\
\hline & Sep 2988 & 0.9 & 17 \\
\hline \multirow[t]{5}{*}{ Kopachi } & Mar 87 & 0.4 & 1.1 \\
\hline & Apr 87 & 5.7 & 6.6 \\
\hline & Sep 1687 & 0.1 & 2.0 \\
\hline & $10 \mathrm{Jul} 88$ & 0.7 & 12 \\
\hline & Sep 2788 & 0.8 & 10 \\
\hline \multirow[t]{5}{*}{ Korogod } & $\operatorname{Mar} 87$ & 0.7 & 0.8 \\
\hline & Sep 1887 & 0.4 & 11 \\
\hline & Jul 788 & 1.4 & 13 \\
\hline & Sep 2488 & 1.5 & 8.8 \\
\hline & Jul 789 & 0.7 & 15 \\
\hline \multirow[t]{5}{*}{ Doviyady } & Jul 1686 & 5.5 & 10 \\
\hline & Jul 1686 & 3.4 & 10 \\
\hline & Oct 1286 & 0.8 & 7.2 \\
\hline & Oct 1686 & 0.6 & 12 \\
\hline & Oct 1686 & 1.6 & 8.4 \\
\hline
\end{tabular}

that the migration of the mobile soluble forms of ${ }^{90} \mathrm{Sr}$ into the lower soil layers is balanced by transformation of its non-exchangeable forms as a result of leaching of the fuel particles. As a result, the content of exchangeable forms of ${ }^{90} \mathrm{Sr}$ in the upper soil layer has not changed in the catchment areas, with the exception of areas in the near zone, where the trail includes "hot" particles and where in recent years rates of radionuclide leaching from the matrix of the "hot" particles have increased, as shown in Figure 4 and Table 4 (Voitsekhovitch et al. 1993a). As a result of these physical-chemical 

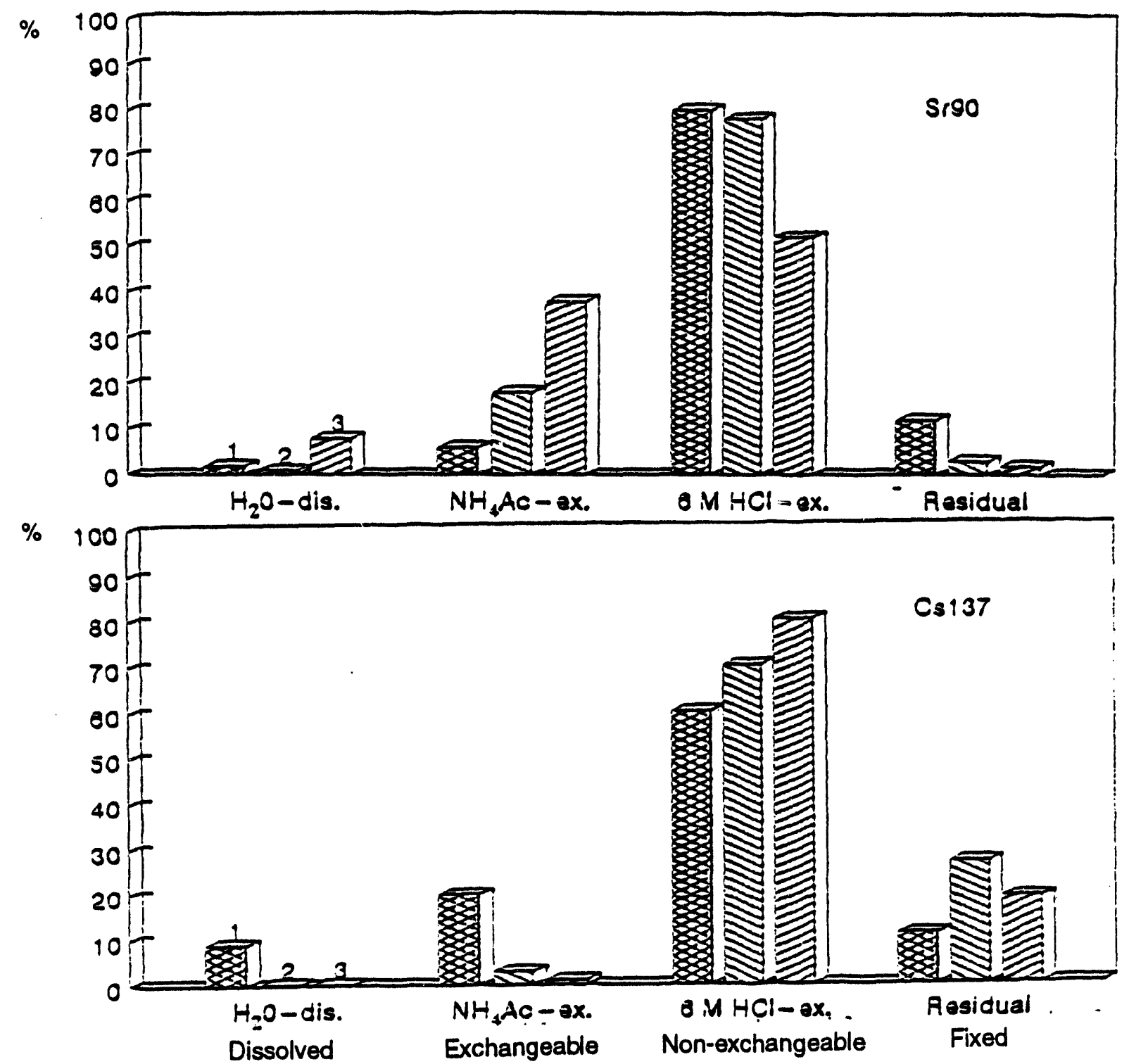

1 - May 1980 precipitation

2 - November 1980 soil

3 - Novemior iagi zcil

Figure 4. Trends of ${ }^{90} \mathrm{Sr}$ and ${ }^{137} \mathrm{Cs}$ Physical-Chemical Forms Transformation in the Floodplain Soils of the Pripyat River Near the Chernobyl Nuclear Power Plant 
Table 4. Time Variation of Mobile Chemical Form in the Floodplain Soil of Nearest Zone Around the Chernobyl Nuclear Power Plant

\begin{tabular}{|l|c|c|}
\hline \multirow{2}{*}{ Years } & $\begin{array}{c}\text { Fraction of Exchangeable Form of Radionuclide } \\
\text { as \% of the Total Radionuclide }\end{array}$ \\
\cline { 2 - 3 } & ${ }^{137} \mathrm{Cs}$ & ${ }^{90} \mathrm{Sr}$ \\
\hline 1986 (autumn) & $0.05-0.1$ & $1-5$ \\
\hline 1987 & $0.1-0.15$ & $6-8$ \\
\hline 1988 & $0.14-0.16$ & $8-15$ \\
\hline 1989 & $0.2-0.3$ & $15-23$ \\
\hline 1990 & $0.6-1.0$ & $25-40$ \\
\hline 1991 & $1.0-1.4$ & $40-60$ \\
\hline
\end{tabular}

transformations, the distributed, non-point sources of secondary ${ }^{137} \mathrm{Cs}$ contamination of Dnieper water have significantly diminished in magnitude during the last few years. In contrast, the current magnitude of ${ }^{90} \mathrm{Sr}$ fluxes to the receiving surface water from the watersheds is close to the values of the first years after the accident.

\subsubsection{River/Reservoir Hydrological Data}

The Dnieper/Pripyat river system is the main surface-water artery of Ukraine. River and reservoir hydrology of this system is measured by Ukrainian Hydrometeorological Institute (Tables 5 and 6). The hydrologic features of these rivers and their tributaries are typical for European rivers with plain watersheds and a forest-steppe landscape. The spring snow melt usually causes flooding of the Pripyat and Dnieper rivers near the Chernobyl area from early March to the middle of May. The historical maximums for water discharges (about $5000 \mathrm{~m}^{3} / \mathrm{s}$ ) and water elevations in the Pripyat River near Chernobyl were measured in May 1970 and May 1979. Since the Chernobyl accident, the spring water discharge did not exceed $1500 \mathrm{~m}^{3} / \mathrm{s}$ in 1987 , and was about $900-1300 \mathrm{~m}^{3} / \mathrm{s}$ in $1988-1993$. 
Table 5. Surface-Water Elevation of the Pripyat River Across the 30-km Zone of Chernobyl During Spring Floods with Different Probabilities of Water Discharges

\begin{tabular}{|c|c|c|c|c|c|c|}
\hline & \multirow{2}{*}{$\begin{array}{c}\text { Water } \\
\text { Probability of Exceeding } \\
\text { the Water Discharge, \% } \\
\text { Discharge } \\
\mathrm{m}^{3} / \mathrm{s}\end{array}$} & \multicolumn{5}{|c|}{ Cerresponded Levels of Water Elevation in Different Cross- } \\
\cline { 3 - 8 } Sections along the Pripyat River & $\begin{array}{c}\text { Chernobyl } \\
26 \mathrm{~km}^{(\mathrm{a})}\end{array}$ & $35 \mathrm{~km}^{(\mathrm{a})}$ & $\begin{array}{c}\text { Yanovbriadge } \\
44 \mathrm{~km}^{(\mathrm{a})}\end{array}$ & $51 \mathrm{~km}^{(\mathrm{a})}$ & $58 \mathrm{~km}^{(\mathrm{a})}$ \\
\hline 1 & 6000 & $106.4^{(\mathrm{b})}$ & $109.5^{(\mathrm{b})}$ & $110.0^{(\mathrm{b})}$ & $110.4^{(\mathrm{b})}$ & 110.5 \\
\hline 5 & 4000 & 105.8 & 108.8 & 109.4 & 109.7 & 109.9 \\
\hline 10 & 3100 & 105.4 & 108.5 & 109.2 & 109.5 & 109.7 \\
\hline 25 & 2000 & 105.0 & 108.0 & 108.6 & 109.2 & 109.5 \\
\hline 50 & 1300 & 104.7 & & 108.1 & & 108.9 \\
\hline \multicolumn{2}{|c|}{} & & & & \\
\hline (a) Distance from the river mouth. \\
(b) Water surface elevation in meters above sea level.
\end{tabular}

Table 6. Main Hydrological Data for Dnieper Reservirs

\begin{tabular}{|c|c|c|c|c|c|c|}
\hline Panmetern & Kiev & Kanev & Kremenchug & Dneprodzerzhin & Zaporoxhie & Kakhov \\
\hline $\mathrm{NHD}^{(a)}$ (m above sea level) & 103.0 & 91.5 & 81.0 & 64.0 & 51.4 & 16.0 \\
\hline LDC (b) (m abovo sea level) & 101.5 & 91.5 & 75.75 & 63.0 & 48.5 & 12.7 \\
\hline Capacity for NHD $\left(\mathrm{km}^{3}\right)$ & 3.73 & 2.62 & 13.51 & 2.45 & 3.3 & 18.21 \\
\hline Capacity for LDC $\left(\mathrm{km}^{3}\right)$ & 2.56 & - & 4.50 & - & 2.47 & 11.4 \\
\hline Area of water shed $\left(1000 \mathrm{~km}^{2}\right)$ & 239 & 336 & 383 & 425 & 463 & 482 \\
\hline Area of water surfice for NHD $\left(\mathrm{km}^{2}\right)$ & 922 & 675 & 2250 & 567 & 410 & 2150 \\
\hline Area of wator aurfice for LDC $\left(\mathrm{km}^{2}\right)$ & 670 & - & 1180 & - & 200 & 1920 \\
\hline Length (km) & 110 & 123 & 149 & 114 & 129 & 230 \\
\hline Maximum width (km) & 12.0 & 8.0 & 28.0 & 8.0 & 7.0 & 25.0 \\
\hline Average width (km) & 8.4 & 5.5 & 15.1 & 5.1 & 3.2 & 9.3 \\
\hline Maximum depth (m) & 14.5 & 21.0 & 20.0 & 16.0 & 53.0 & 24.0 \\
\hline Average depth (m) & 4.0 & 3.9 & 6.0 & 4.3 & 8.0 & 8.5 \\
\hline Perimetor (km) & 520 & 510 & 800 & 358 & 250 & 900 \\
\hline Minimum discharge in summer $\left(\mathrm{m}^{3} / \mathrm{sec}\right)$ & 200 & 200 & 200 & 200 & 200 & 200 \\
\hline Maximum reconded discharge $\left(\mathrm{m}^{3} / \mathrm{sec}\right)$ & 15300 & 23200 & 23900 & 24100 & 24500 & 19300 \\
\hline Annlisl Mean outflow volume $\left(\mathrm{km}^{3} / \mathrm{y}\right)$ & 33.1 & 43.9 & 47.8 & 52.0 & 52.2 & 52.2 \\
\hline Averaged flow velocity (cm/sec) & 3.0 & 7.6 & 2.0 & 7.1 & $\overline{6.4}$ & 1.6 \\
\hline Mean sedimentation rate (cm/year) & 0.70 & 2.0 & 0.94 & 0.98 & 1.37 & 0.8 \\
\hline $\mathrm{pH}$ & \multicolumn{6}{|c|}{$7.2-8$} \\
\hline
\end{tabular}


Until 1993, rainfall flooding had a maximum discharge below $900 \mathrm{~m}^{3} / \mathrm{s}$. High spring floods usually transport greater amounts of water and therefore larger amounts of radionuclides than rainfall-caused floods. However, even rainfall floods could significantly increase the radionuclide influx into the Pripyat River, thus also to the Kiev Reservoir. The highest floods on the Pripyat River since the accident have been in July 1988 with the maximum water discharge of $900 \mathrm{~m}^{3} / \mathrm{sec}$, October-November 1989 with $450 \mathrm{~m}^{3} / \mathrm{sec}$, and fall of 1990 with $580 \mathrm{~m}^{3} / \mathrm{s}$. During these rainfall-caused floods, radionuclides were washed out from the contaminated watersheds and flowed out from the lowelevation areas near the old floodplain-channel streams. However, as will be discussed in Section 2.1.6 (Radionuclide Dynamics During the Flood), the flooding of the most contaminated part of the Pripyat River floodplain near the Chernobyl Nuclear Power Plant occurred not under normal snow-melt or rainfall-caused flooding, but as a result of a rise in water elevation due to the formation of an ice jam in the Pripyat River channel downstream from the Chernobyl Nuclear Power Plant.

The Pripyat River carries sand, silt, and clay materials; more than $80 \%$ of the total sediment transport in rivers is usually due to the suspended sediment. Ordinary suspended sediment transport in the Pripyat River in summer has a range of $20-40 \mathrm{~kg} / \mathrm{s}$. During spring floods with Pripyat water discharges of more than $1500 \mathrm{~m}^{3} / \mathrm{s}$, the sediment transport rate can exceed $200-250 \mathrm{~kg} / \mathrm{s}$. During lowflow periods, suspended concentrations in the Pripyat River are $30-50 \mathrm{mg} / \mathrm{L}$. During spring floods, the concentration can exceed $250 \mathrm{mg} / \mathrm{L}$.

The sediment transport rate in the Dnieper River during middle-sized floods, with water discharge less than $2000 \mathrm{~m}^{3} / \mathrm{s}$, does not exceed $40-50 \mathrm{~kg} / \mathrm{s}$. Usually, in spring, sand accounts for $20-30 \%$ of sediment being transported; silt is $40-60 \%$, and clay ranges less than $30 \%$. During the low-flow periods, suspended solids in the Pripyat River mostly consist of organic/mineral silt and clay particles 
(60-70\%). In winter, the organic/mineral silt and clay fraction of sediment transported in rivers is 70-90\%. The suspended matter concentration in the Kiev Reservoir is usually less than $20 \mathrm{mg} / \mathrm{L}$, with 5-15 mg/L being clay and organic matter (Table 6).

\subsubsection{River/Reservoir Data - Primary Radionuclide Contamination}

Immediately after the accident, the surface water bodies were affected by the direct precipitation of aerosol fallout onto the water surface. Radionuclide concentrations in the rivers during the period after May 1, 1986, revealed a sharp change in the water contamination level at the end of the fallout period. Total beta activity in the Pripyat River water exceeded $10^{-7} \mathrm{Ci} / \mathrm{L}$ in the first days after the accident but had decreased to $4.6 \times 10^{-9} \mathrm{Ci} / \mathrm{L}$ by the end of May 1986 .

Maximum plutonium concentrations observed in the Pripyat River in the first days after the accident were about $10 \mathrm{pCi} / \mathrm{L}$ but decreased to $0.2 \mathrm{pCi} / \mathrm{L}$ by August 1986 . They were four orders of magnitude lower than the maximum permissible level of soluble plutonium for drinking water. Up to $98 \%$ of the plutonium in the water bodies was associated with suspended and bottom sediments. Therefore, the emphasis of the field and experimental studies on radioactive contamination of water bodies was on ${ }^{90} \mathrm{Sr}$ and ${ }^{137} \mathrm{Cs}$ (Voitsekhovitch et al. 1990, 1991; Vakulovsky et al. 1991). The rivers, creeks, lakes, and floodplain water located near the Chernobyl Nuclear Power Plant were initially contaminated by direct deposition of radioactive substances onto the water surface and riverbed. In small rivers, this mode of contamination continued through the whole month of May 1986. The level of radioactive contamination was determined by the rate of fallout deposition onto the river surface and

dissolved in the water. The content of ${ }^{90} \mathrm{Sr}$ in various water bodies was determined from May 1, 1986, 
onwards. The highest levels were observed in the first few days of May 1986 in the Pripyat River, reaching $400 \mathrm{pCi} / \mathrm{L}$. From the end of May until June, the ${ }^{90} \mathrm{Sr}$ content in the Pripyat River remained within the range $30-50 \mathrm{pCi} / \mathrm{L}$. Ratios of ${ }^{137} \mathrm{Cs}$ adsorbed by each sediment size fraction to the total sorbed ${ }^{137}$ Cs over several years are shown in Figures 5 and 6, showing clear preference for finer sediment by ${ }^{137} \mathrm{Cs}$.

The Dnieper reservoirs were contaminated almost immediately after the accident by deposition of radioactive substances from the atmosphere. According to some estimations (Iz ." et al. 1991), the total amount of radioactive substances that were deposited on the aquatic surfaces of the Pripyat River and the Kiev Reservoir reached approximately $35 \times 10^{5} \mathrm{Ci}$. During first several days after the accident, the total specific activity of water in the Kiev Reservoir and the Dnieper River near a Kiev drinking water incake exceeded $100 \mathrm{pCi} / \mathrm{L}$. Almost the whole activity (99\%), except iodine, was associated with suspended particles; activity in a sample that was taken on April 30 from the Kiev Reservoir near the town of Lutezh (at the southern end of the reservoir) reached $10 \mu \mathrm{Ci}$ per kilogram of dry weight sediment.

Later, when the intensive radioactive release to the atmosphere from the damaged reactor ended, the aerosol component of reservoir contamination decreased rapidly and suspended particles precipitated to the bottom; by May 10,1986, the total specific radioactivity of water in the lower part of the Kiev Reservoir had decreased to about $10^{3} \mathrm{pCi} / \mathrm{L}$. 


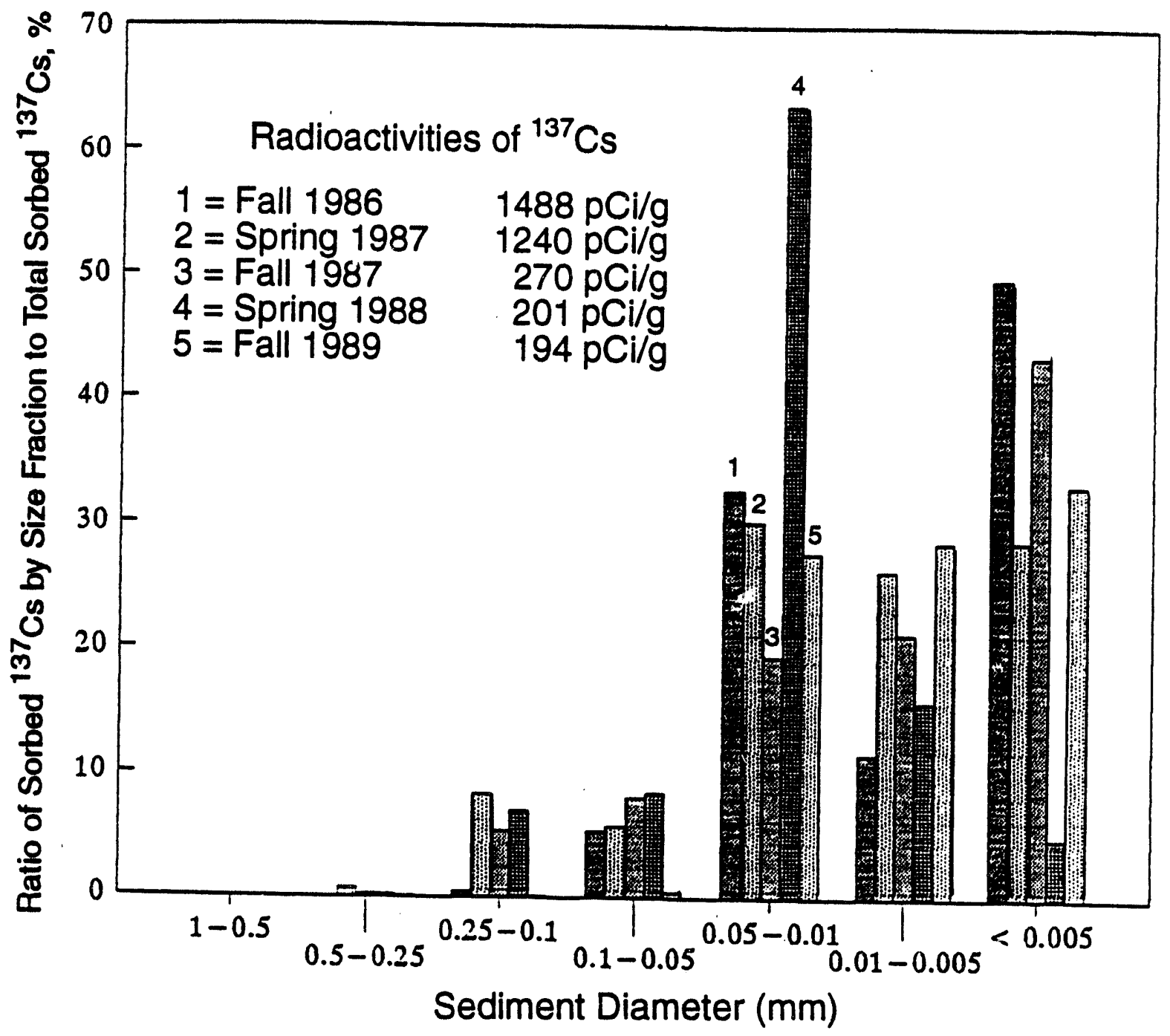

Figure 5. ${ }^{137} \mathrm{Cs}$ Distribution on the Suspended Particles of the Pripyat River near the Town of Chernobyl

The highest contamination levels in the waters of the reservoirs in the Dnieper cascade were also registered in the initial period after the accident. The total beta activity of the water in the period of aerosol fallout reached $100 \mu \mathrm{Ci} / \mathrm{L}$. The radioactivity of the water in this period came primarily from particles suspended in the water. The activity of the filtrate accounted for only about $10 \%$ of the total activity of gamma-emitters in the sample. 


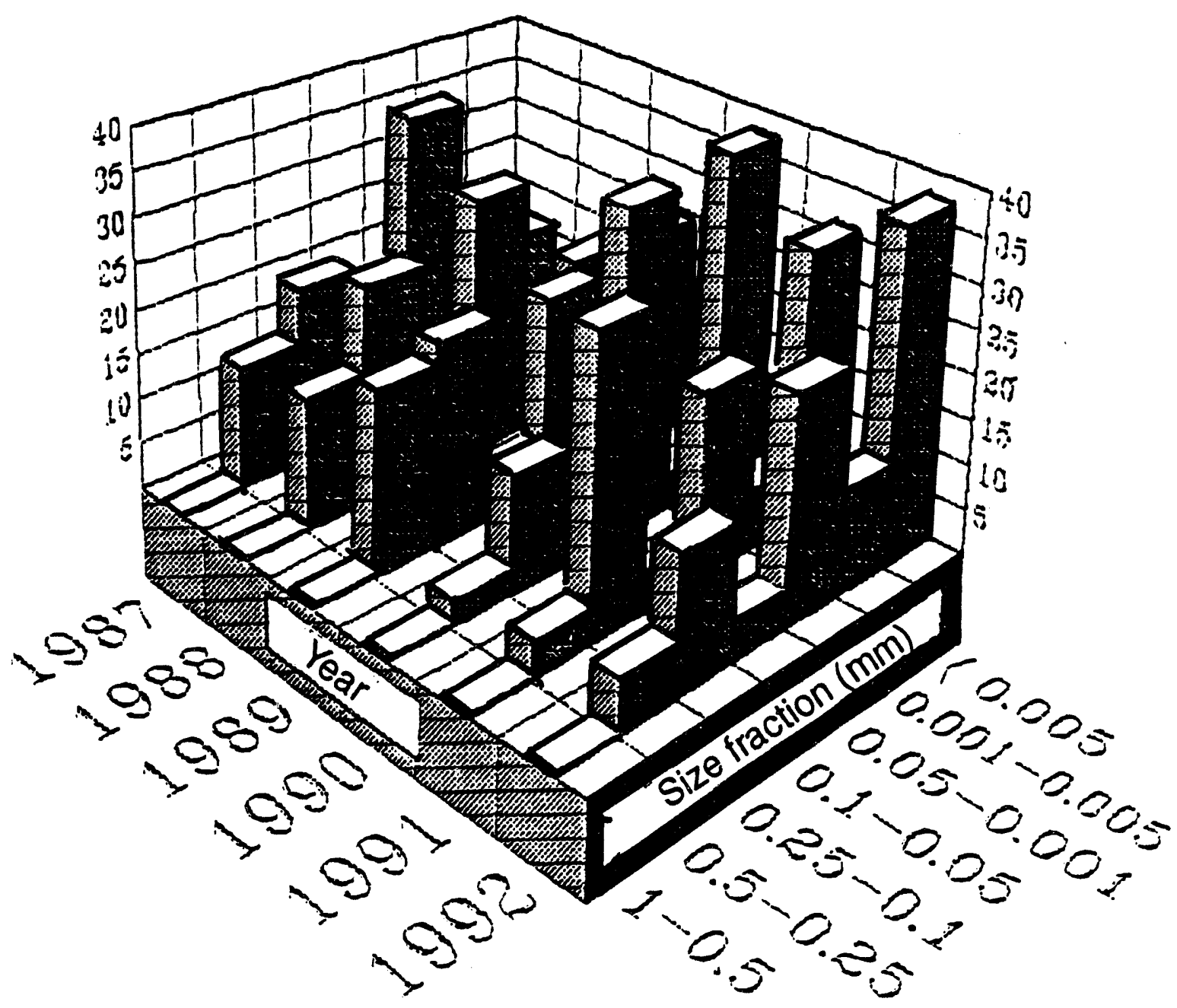

Figure 6. ${ }^{137}$ Cs Distribution on the Suspended Particles of the Pripyat River near the Chernobyl Nuclear Power Plant

After the fallout period, the sharp drop in the intensity of emissions from the Chernobyl Nuclear Power Plant led to a reduction in the contribution by the aerosol component in reservoir contamination. Suspended particles settled quickly onto the beds of the reservoirs, and by May 7, 1986, the total beta activity of the water in the central districts of the reservoir also decreased to about $10 \mathrm{pCi} / \mathrm{L}$. 
Contamination by the radionuclide ${ }^{131} \mathrm{I}$ had a significant role in the risk of radiation exposure to populations through the aquatic pathway during the initial period. The highest ${ }^{131}$ I content in the Dnieper River, which was observed in the Dnieper drinking water intake area, came from fallout of radioactive aerosols and reached $3000 \mathrm{pCi} / \mathrm{L}$ on May 3, 1986. Once atmospheric fallout of radioactive aerosols onto the water surface had ceased, secondary radionuclide migration processes became the main source of water contamination. The two most important of these processes were

a) radionuclide washout from contaminated catchment areas and river floodplains; and

b) radionuclide mass-exchange processes in the "bed-sediment/water" system. The intensity of secondary water-contamination processes was determined largely by the physical-chemical forms of the radionuclide fallout and by their rate of transformation in the "soil-water" system.

\subsubsection{Radionuclide Influx to the Dnieper Reservoirs}

Radionuclide levels in the Pripyat and Dnieper rivers obtained from the Ukrainian monitoring system for the post-accident period are presented in Figures 7 and 8 and in Table 7 (Voitsekhovitch et al. 1993a).

These data show quite different trends in the temporal variation of ${ }^{137} \mathrm{Cs}$ and ${ }^{90} \mathrm{Sr}$ fluxes. The annual flux of ${ }^{137} \mathrm{Cs}$ from the Pripyat River to the Kiev Reservoir decreased from almost $1500 \mathrm{Ci}$ in 1986 to about $250 \mathrm{Ci}$ in 1987 to $35 \mathrm{Ci}$ in 1992 . The annual flux of ${ }^{90} \mathrm{Sr}$, however, has not changed significantly during 1987-1991; it was about $280 \mathrm{Ci}$ in 1987, near $500 \mathrm{Ci}$ in 1988, $388 \mathrm{Ci}$ in 1991, and about $100 \mathrm{Ci}$ in 1992 (Table 7). These data agree with the indirect estimates of the annual catchment radionuclide fluxes of ${ }^{137} \mathrm{Cs}$ and ${ }^{90} \mathrm{Sr}$ obtained from the process described in Table 3. 

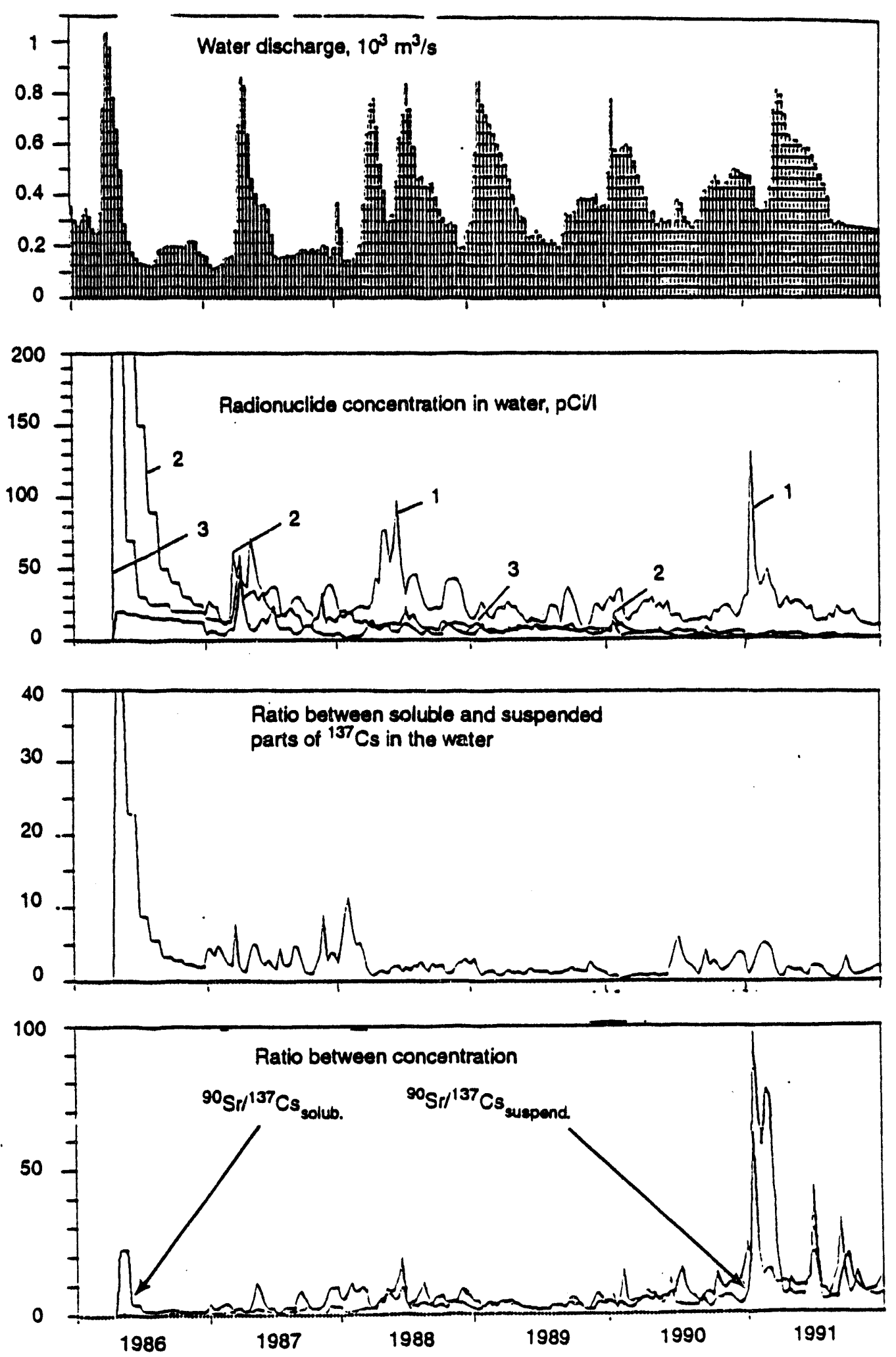

Figure 7. Time Variations of Water Discharge and of ${ }^{137} \mathrm{Cs}$ and ${ }^{90} \mathrm{Sr}$ Concentrations (daily averaged data) after the Accident for the Pripyat River, at the Town of Chernobyl. 1, 2, and 3 on the above figure represent ${ }^{90} \mathrm{Sr}$, soluble ${ }^{137} \mathrm{Cs}$, and particulate ${ }^{137} \mathrm{Cs}$. 

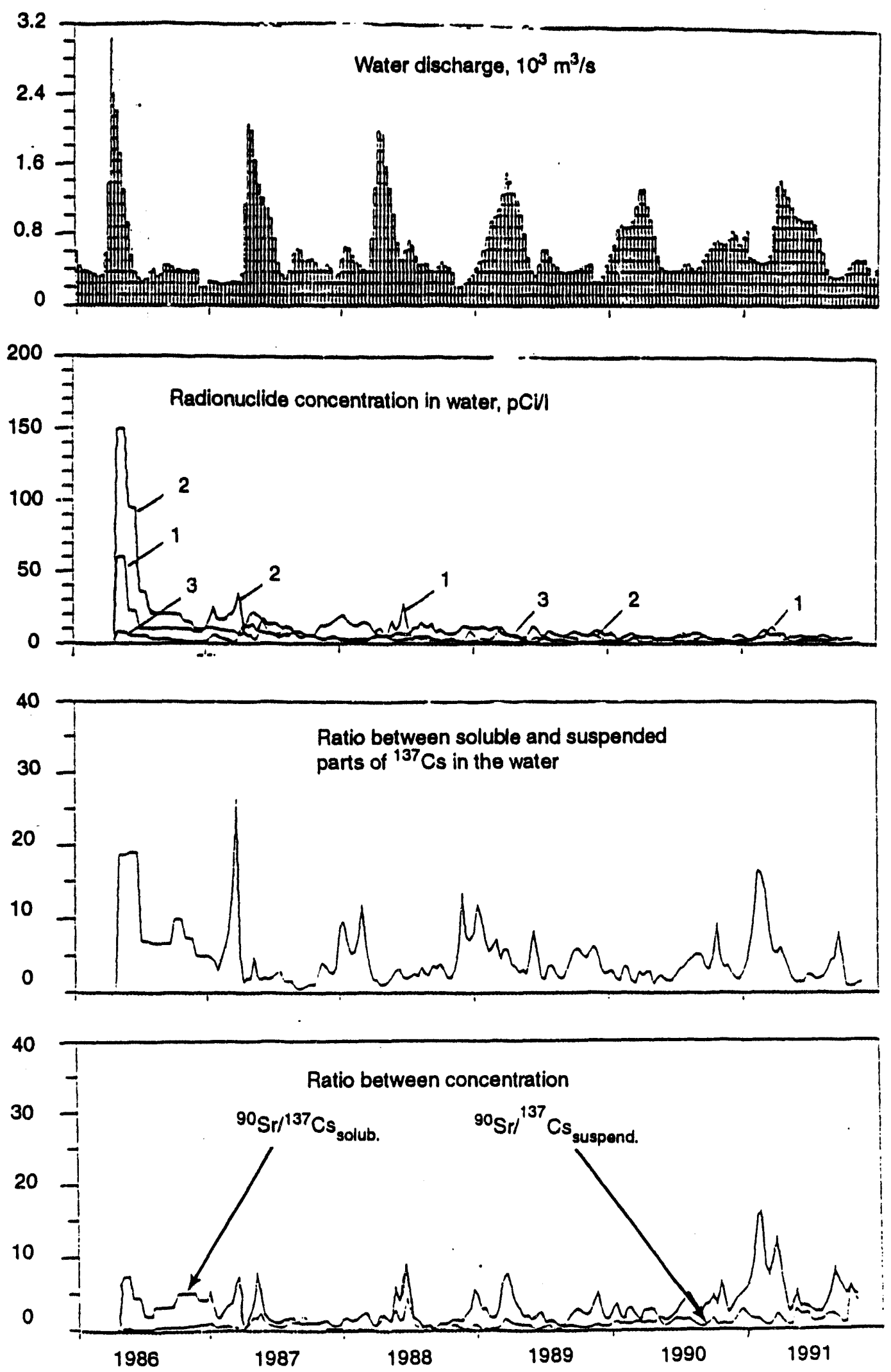

Figure 8. Time Variations of Water Discharge, and of ${ }^{137} \mathrm{Cs}$ and ${ }^{90} \mathrm{Sr}$ Concentrations (ten-day averaged data) and Their Ratio after the Accident for the Dnieper River at Nedanchychy. 1, 2, and 3 on the above figure represent ${ }^{90} \mathrm{Sr}$, soluble ${ }^{137} \mathrm{Cs}$, and particulate ${ }^{137} \mathrm{Cs}$. 
Table 7. Annual Dnieper and Pripyat Rivers Radionuclide Flux $(\mathrm{Ci} / \mathrm{y})$ and Washout Coefficients $\left(\mathrm{K}_{\mathcal{L}}\right.$ from Their Catchment During the Period after the Accident ( $\mathrm{mm}^{-1}$ )

\begin{tabular}{|c|c|c|c|c|c|}
\hline Years & $\begin{array}{c}\text { Soluble } \\
{ }^{137} \mathrm{Cs}\end{array}$ & $\begin{array}{c}\text { Suspended } \\
{ }^{3}{ }^{\mathrm{Cs}}\end{array}$ & $\mathrm{K}_{\mathrm{L}}{ }^{137} \mathrm{Cs}$ & ${ }^{90} \mathrm{Sr}$ & $\mathrm{K}_{\mathrm{L}}{ }^{90} \mathrm{Sr}$ \\
\hline 1986 & 1480 & 80 & & 725 & \\
\hline 1987 & 242 & 107 & $1.70 \times 10^{-5}$ & 277 & $8.6 \times 10^{-5}$ \\
\hline 1988 & 162 & 97 & $0.74 \times 10^{-5}$ & 506 & $9.8 \times 10^{-5}$ \\
\hline 1989 & 98 & 77 & $0.47 \times 10^{-5}$ & 243 & $5.0 \times 10^{-5}$ \\
\hline 1990 & 58 & 65 & $0.26 \times 10^{-5}$ & 224 & $4.3 \times 10^{-5}$ \\
\hline 1991 & 38 & 27 & $0.16 \times 10^{-5}$ & 388 & $7.1 \times 10^{-5}$ \\
\hline Total & 2078 & 453 & & 2363 & \\
\hline \multicolumn{7}{|c|}{ Pripyat River at Chernobyl } \\
\hline 1986 & 720 & 50 & & 280 & \\
\hline 1987 & 244 & 113 & $0.14 \times 10^{-5}$ & 223 & $16.0 \times 10^{-5}$ \\
\hline 1988 & 188 & 70 & $0.14 \times 10^{-5}$ & 141 & $7.1 \times 10^{-5}$ \\
\hline 1989 & 155 & 34 & $0.14 \times 10^{-5}$ & 97 & $5.0 \times 10^{-5}$ \\
\hline 1990 & 96 & 42 & $0.14 \times 10^{-5}$ & 92 & $5.2 \times 10^{-5}$ \\
\hline 1991 & 71 & 32 & $0.14 \times 10^{-5}$ & 105 & $5.8 \times 10^{-5}$ \\
\hline Total & 1474 & 341 & & 938 & \\
\hline & & & & & \\
\hline
\end{tabular}

The decrease in flux values as well as the washout coefficients for ${ }^{137} \mathrm{Cs}$ in the Pripyat River and its catchments shown in Table 7 reflect the rapid fixation of ${ }^{137} \mathrm{Cs}$ in the soils. No similar phenomenon was observed for ${ }^{90} \mathrm{Sr}$. This disparity can be explained by the fact that migration of mobile forms of ${ }^{90} \mathrm{Sr}$ into the surface unsaturated layers was compensated by transformation of ${ }^{90} \mathrm{Sr}$ from nonexchangeable to exchangeable forms and as a result of leaching from the "hot" particles to the environment. Data for the dynamics of mobile forms of ${ }^{90} \mathrm{Sr}$ and ${ }^{137} \mathrm{Cs}$ on the floodplain soils of the area near Chernobyl were given in Table 4. The differences in ${ }^{90} \mathrm{Sr}$ and ${ }^{137} \mathrm{Cs}$ fixation mechanisms in catchment 
and floodplain soils are also reflected in their transport by the Dnieper and Pripyat rivers (Figures 7 and 8). Seasonal variations in ${ }^{90} \mathrm{Sr}$ and ${ }^{137} \mathrm{Cs}$ ratios in Figures 7 and 8 also reflect flooding of the areas near Chernobyl that had high levels of ${ }^{90} \mathrm{Sr}$ contamination in soils.

The water transport of radionuclides, especially ${ }^{137} \mathrm{Cs}$, is determined primarily by the suspended materials resulting from erosion of small soil and sediment particles from the catchment and resuspension of bed sediment by river channel erosion processes. Chronological data on the 10-dayaveraged ratio between ${ }^{137} \mathrm{Cs}$ associated with suspended sediments (particles up to $1 \mathrm{~mm}$ in diameter) and dissolved ${ }^{137} \mathrm{Cs}$ serve as an indicator of the importance of sediments in ${ }^{137} \mathrm{Cs}$ river transportation. The observed ratio of suspended and solution ${ }^{137} \mathrm{Cs}$ for the post-accident period is shown in Figures 6 and 7. The percentage of suspended-sediment sorbed ${ }^{137} \mathrm{Cs}$ varies from 20 to $80 \%$ depending on resuspension conditions, catchment erosion, and flow transportability. From 1987 to 1991 , the contribution of the radionuclides associated with suspended sediments remained $30-40 \%$ of the total radionuclide flux in of the Pripyat River. Meanwhile, the specific activity of suspended ${ }^{137} \mathrm{Cs}$ in the Pripyat River by the end of 1986 had reached $3000-30,000$ pCi/g. By $1990-1992$ it had decreased to $30-300 \mathrm{pCi} / \mathrm{g}$, as calculated for the suspended element in samples on ordinary filters or in special sediment traps in the field. The trend in ${ }^{137} \mathrm{Cs}$ fluxes for recent years indicates that while washout of soluble forms of radionuclide has decreased, changes in the amount eroded have been insignificant. As a result, there has been marked growth in the contribution of the suspended component relative to total radionuclide flux in the river. Transport of river sediment, however, does not play any significant role in ${ }^{90} \mathrm{Sr}$ migration. These data provide a clear indication that the time variation of radionuclide influx to the reservoir system depends on peculiarities of hydrological conditions and on the physical-chemical species of the radionuclides in the contaminated catchments. 


\subsubsection{Radionuclide Distribution in the Dnieper Reservoirs}

The six reservoirs on the Dnieper River, which were described in Table 6, are the main source of surface water for consumption in Ukraine. During its near-900-km journey across the Ukrainian territory from the mouth of the Pripyat River to the Black Sea, Dnieper River water is used for drinking, municipal, and industrial needs and for irrigation. Canals transport the Dnieper's water from Kakhovlca Reservoir to the industrial Donbass region, to the Crimean Peninsula, and to the irrigated land of southern Ukraine. As a result, 20 to 30 million Ukrainians have been affected by radionuclides in the Dnieper's water since the Chernobyl accident.

The highest contamination levels for the Dnieper cascade reservoirs were registered in the initial period after the accident. Later, with the sharp decrease of the radioactive releases from the Chernobyl Nuclear Power Plant, the impact of the aerosol component on reservoir contamination became lower; a fairly rapid sedimentation on the Kiev Reservoir bottom took place, and by May 7, 1986, the total beta activity in water in the lower part of the Kiev Reservoir was already down to about $10 \mathrm{pCi} / \mathrm{L}$.

For the post-accident years, almost $95 \%$ of the ${ }^{137} \mathrm{Cs}$ that entered the Dnieper River was deposited in the bottom of all the Dnieper reservoirs (Voitsekhovitch et al. 1993b). Thus, the contribution of

${ }^{137}$ Cs discharged to a northeastern part of the Black Sea for this period (during which annual Dnieper River flow was below the norm) was insignificant relative to radionuclide amount in the northwestern part of the Black Sea. 
Temporal and spatial distributions of radionuclide concentrations in the Dnieper reservoirs, measured by the Ukrainian Hydrometeorological Institute, are presented in Figures 9 and 10. The distribution of ${ }^{90} \mathrm{Sr}$ in the Dnieper reservoirs shows that fixation of the radionuclide by bottom sediments is not very firm (Figures 10 and 11), and that water in the lower reservoirs is affected by ${ }^{90} \mathrm{Sr}$ radiation to an even greater degree than was observed for ${ }^{137} \mathrm{Cs}$ (Voitsekhovitch et al. 1993a).

Most ${ }^{90} \mathrm{Sr}$ inflow to the Kiev Reservoir passes through the six reservoirs of the Dnieper cascade as transit elements and thus can enter the lower Dnieper area, where the radionuclide concentration is near the water irrigation standard of $7 \mathrm{pCi} / \mathrm{L}$ for ${ }^{90} \mathrm{Sr}$. The level for ${ }^{90} \mathrm{Sr}$ was $5-10 \mathrm{pCi} / \mathrm{L}$ in $1991-1992$. During 1992 , the average ${ }^{90} \mathrm{Sr}$ content ranged from $20-30 \mathrm{pCi} / \mathrm{L}$ near the mouth of the Pripyat River to 1-5 $\mathrm{pCi} / \mathrm{L}$ in the lower reservoirs. The reservoir water contamination level for ${ }^{137} \mathrm{Cs}$ for $1991-1993$, was somewhat lower, $0.1-1 \mathrm{pCi} / \mathrm{L}$, which is close to the background level caused by global radioactive fallout.

The same tendencies were observed for suspended matter being transported by water flow along the Dnieper reservoir system. Typical distributions of suspended matter in water and the associated ${ }^{137} \mathrm{Cs}$ contamination along the Dnieper cascade measured by the Ukrainian Hydrometeorological Institute in the summer of 1988 are shown in Table 8. Most of the suspended sediment released from the river to the reservoir is deposited on the bottoms of the upper parts of the reservoirs. However, some of the finest particles (usually with a size of less than $50 \mu \mathrm{m}$ ) could be carried away by flow to the next reservoir and on down to the lower parts of the cascade. A considerable flux of radionuclides into the lower reservoirs has been observed during storms and in periods of high water. Up to $50 \%$ of the ${ }^{137} \mathrm{Cs}$ influx to the reservoirs is carried with the fine sediment particles, and up to $80 \%$ of the river 

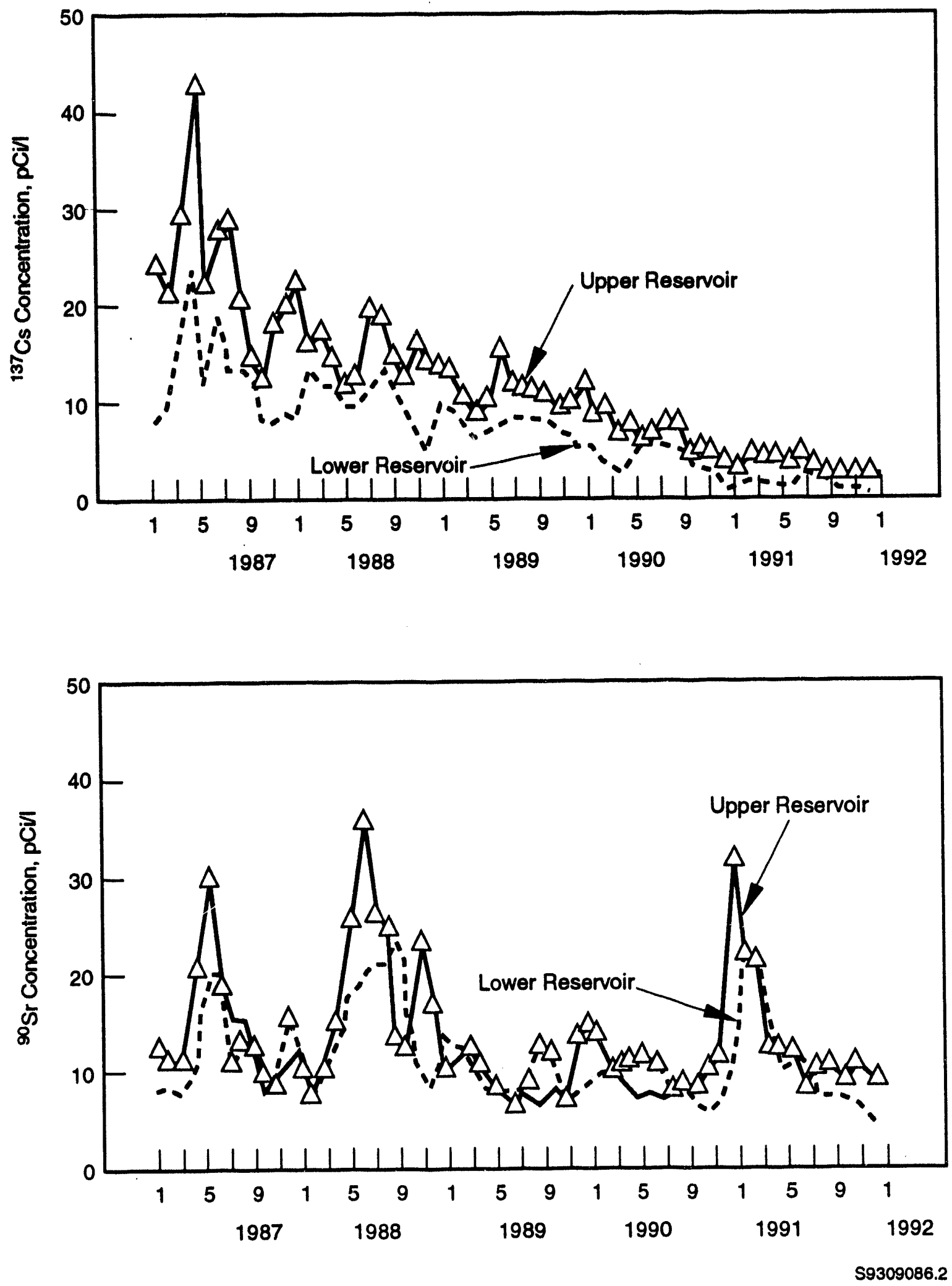

Figure 9. Radionuclide Contamination of the Kiev Reservoir after the Accident (Voitsekhovitch and Kanivets 1993). 

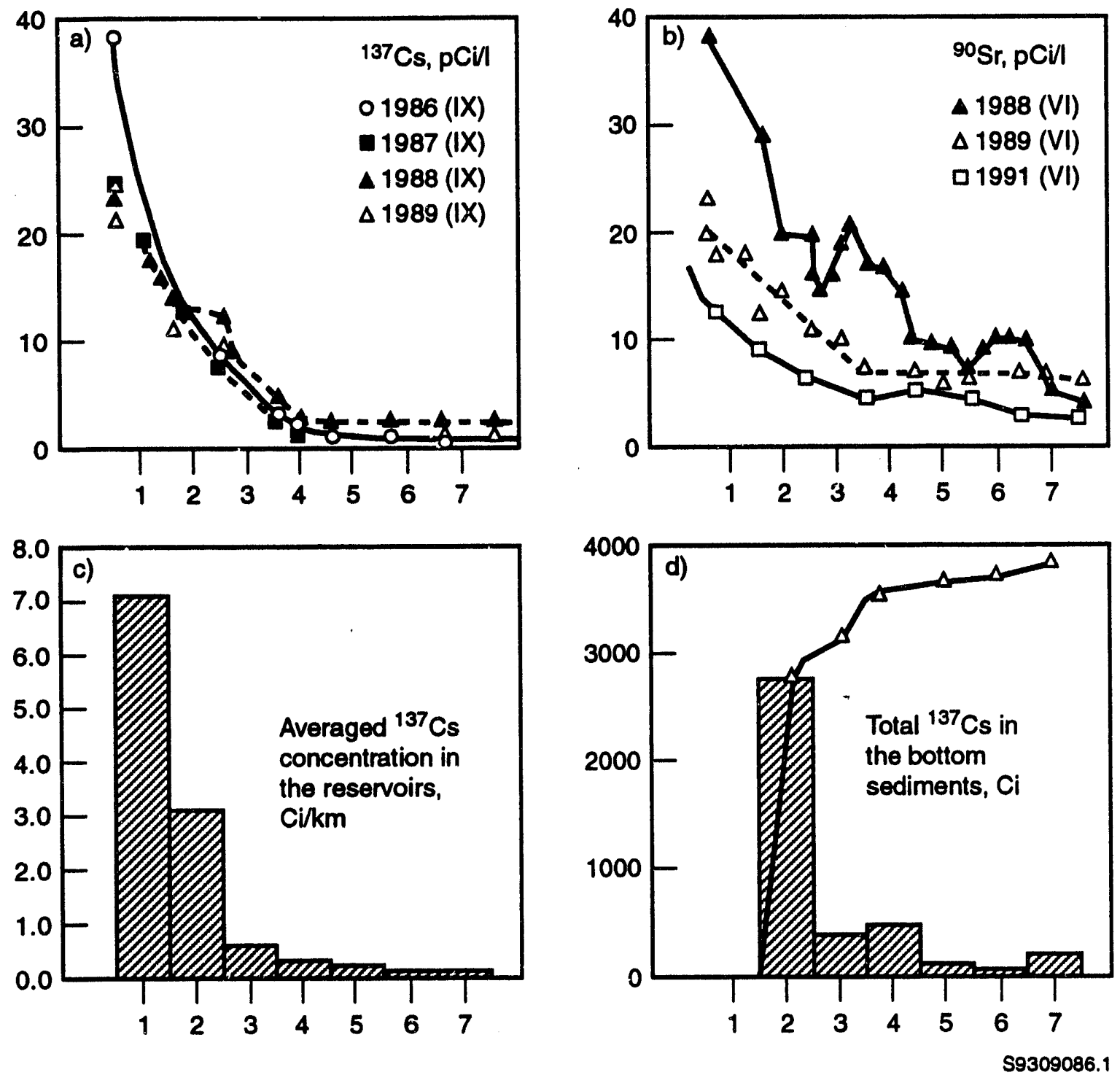

Figure 10. Radioactive Contamination of the Dnieper Reservoirs After the Chernobyl Accident (a) ${ }^{137} \mathrm{Cs}$ Concentrations in Water, (b) ${ }^{90} \mathrm{Sr}$ Concentrations,

(d) Total ${ }^{137} \mathrm{Cs}$ in Bottom Sediment. In these figures, 1 indicates mouth of the Pripyat River, 2 through 7 indicates six reservoirs in the Pripyat River from Kiev Reservoir to Kakhovka reservoirs. 


\section{Radionuclide Concentration, $\mathrm{pCil}$}

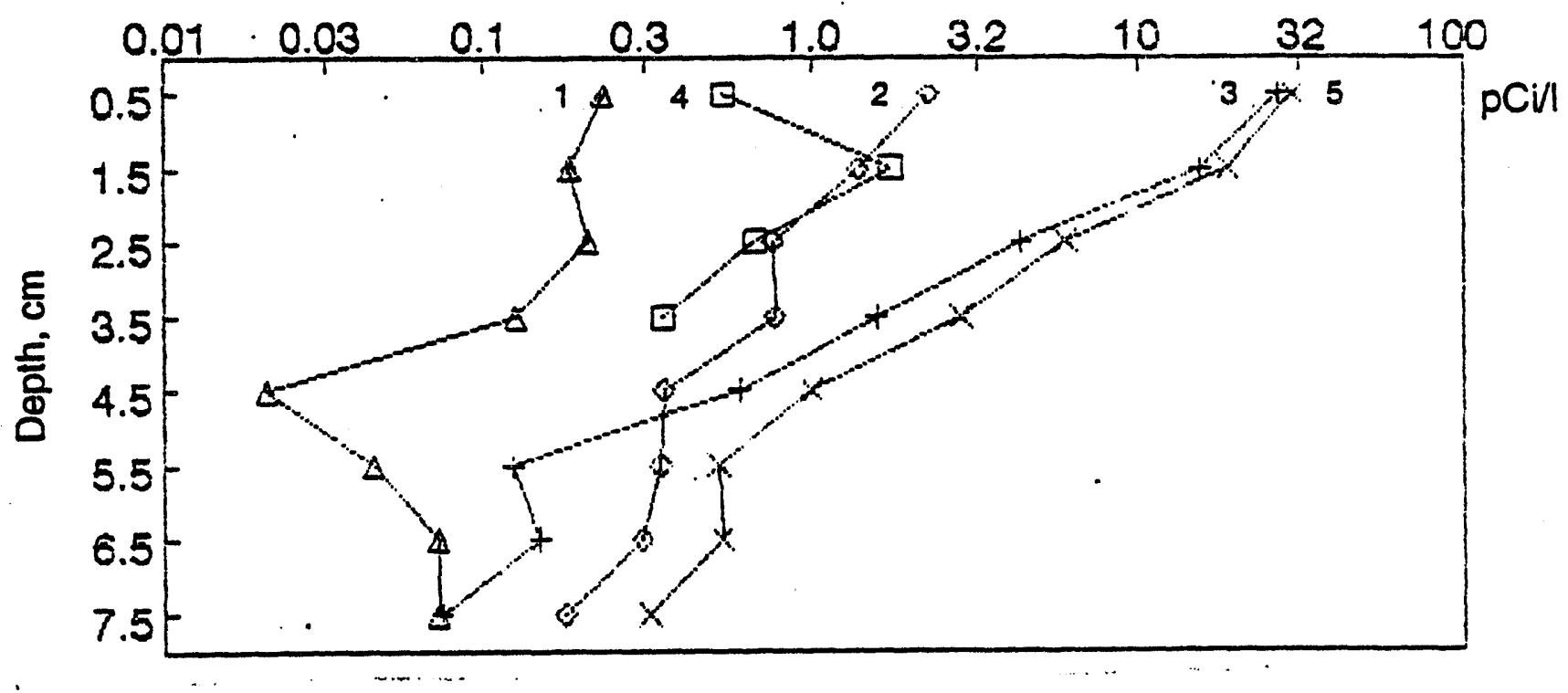

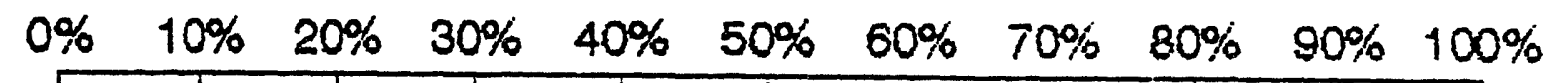

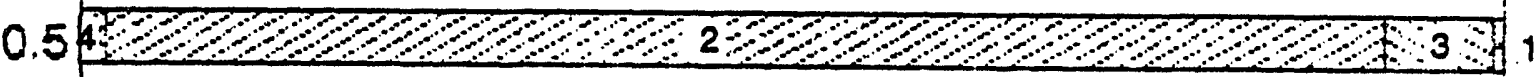

$1.5 \% 4822020202020201$

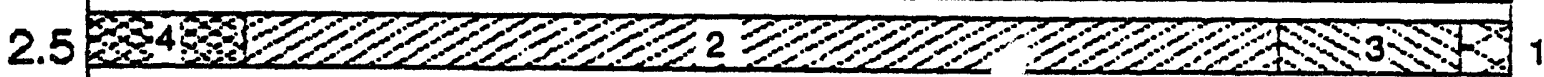

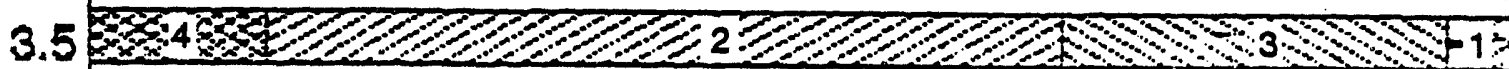

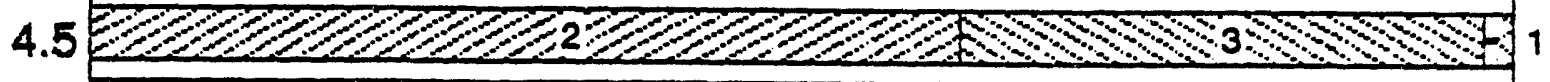

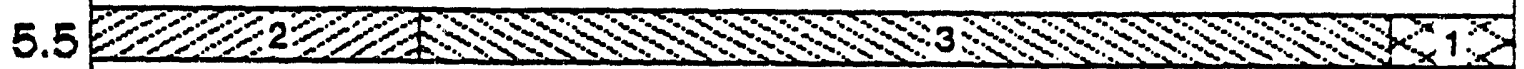

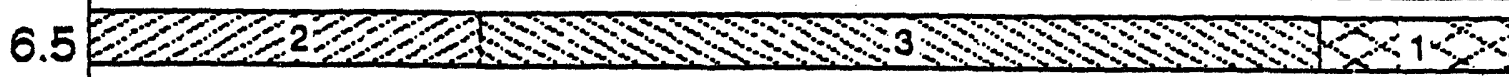

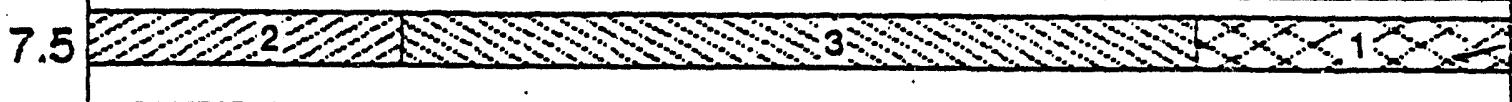

$\mathrm{Z}, \mathrm{cm}$

Figure 11. Vertical Distribution of Different Physical-Chemical Forms of ${ }^{90} \mathrm{Sr}$ in the Bottom Sediments of the Kiev Reservoir, in the Upper Part of the Area of Suspended Particles Deposition, May 1991 (Voitsekhovitch et al. 1993). 1 indicates waterdissolved form, 2 exchangeable form, 3 nonexchangeable form, 4 fixed form, and 5 the total. 
Table 8. Distributions of Suspended Sediments and their Associated Radionuclides along the Dnieper Cascade in 1988

\begin{tabular}{|c|c|c|c|c|c|c|c|c|c|}
\hline \multirow[b]{2}{*}{ Date } & \multirow{2}{*}{$\begin{array}{l}\text { Region on Cross } \\
\text { Section }\end{array}$} & \multirow{2}{*}{$\begin{array}{l}\text { Sediment } \\
\mathrm{g} / \mathrm{m}^{3}\end{array}$} & \multirow{2}{*}{$\begin{array}{l}{ }^{137} \mathrm{Cs} \\
\mathrm{pCi} / \mathrm{g}\end{array}$} & \multicolumn{6}{|c|}{ Size Distribution for Dinm. in mm, $\%$} \\
\hline & & & & $0.5-0.2$ & $0.2-0.1$ & $0.1-0.05$ & $0.05-0.01$ & $0.01-0.005$ & $<0.005$ \\
\hline 23 May & Dnieper-Nedanchichi & 22.7 & 117.6 & 2.9 & 17.3 & 4.0 & 52.9 & 11.7 & 11.2 \\
\hline 22 May & Pripyat-Chernobyl & 29.3 & 361.7 & 1.1 & 13.0 & 18.9 & 13.3 & 12.5 & 41.2 \\
\hline \multicolumn{10}{|c|}{ Kiev Reservoir } \\
\hline 27 May & upper & 13.4 & 384.6 & 0.2 & 7.0 & 10.6 & 42.0 & 11.0 & 29.2 \\
\hline 27 May & modial & 5.7 & 629.0 & 0.1 & 0.2 & 7.6 & 62.1 & 5.0 & 25.0 \\
\hline $27 \mathrm{May}$ & lower & 4.1 & 650.0 & 1.2 & 0.6 & 0.3 & 44.0 & 27.1 & 26.8 \\
\hline \multicolumn{10}{|c|}{ Kanev Reservoir } \\
\hline 1 June & upper & 10.0 & 350.0 & 0.0 & 1.0 & 0.3 & 16.7 & 28.1 & 54.0 \\
\hline 7 June & modial & 4.0 & 227.0 & 1.1 & 0.2 & 7.8 & 43.3 & 17.5 & 30.0 \\
\hline 8 June & lower & 3.7 & 180.0 & 0.1 & 0.7 & 1.2 & 42.0 & 9.4 & 46.6 \\
\hline \multicolumn{10}{|c|}{ Kromenchug Reservoir } \\
\hline 14 June & upper & 9.6 & 21.9 & 0.0 & 0.9 & 15.7 & 50.6 & 19.4 & 13.4 \\
\hline 15 June & lower & 6.1 & 30.8 & 0.0 & 3.3 & 1.0 & 38.7 & 20.7 & 36.3 \\
\hline \multicolumn{10}{|c|}{ Dneprodzorzhin Reservoir } \\
\hline 16 June & upper & 4.0 & 58.8 & 2.5 & 0.3 & 2.1 & 58.5 & 26.3 & 10.3 \\
\hline 18 June & lower & 7.3 & 44.3 & 0.0 & 1.1 & 1.9 & 62.6 & 25.0 & 9.4 \\
\hline \multicolumn{10}{|c|}{ Dneprov Reservoir } \\
\hline 20 June & upper & 7.1 & 20.0 & 1.2 & 2.1 & 0.9 & 40.6 & 38.1 & 17.1 \\
\hline 21 June & lower & 4.6 & 39.6 & 0.0 & 2.5 & 1.4 & 64.1 & 8.1 & 23.9 \\
\hline \multicolumn{10}{|c|}{ Kalhovkn Reservoir } \\
\hline 23 June & upper & 4.2 & 12.2 & 7.0 & 15.0 & 9.3 & 34.3 & 11.2 & 23.1 \\
\hline 24 June & lower & 2.4 & 20.1 & 0.0 & 0.6 & 6.0 & 19.9 & 7.3 & 66.3 \\
\hline
\end{tabular}

suspended sediments are deposited in the upper parts of the cascade. This pattern indicates the important role of the sorption capacity of the suspended sediments and reservoir soils in the process of purification of contaminated water. The process of radionuclide accumulation in the reservoirs can be expected to continue. 
As discussed previously, the bottom sediments of reservoirs were initially contaminated by the direct radioactive fallout to the water surface, thus original contamination levels of the bottom sediments in these reservoirs corresponded to the contamination levels in nearby coastal areas. But, due to the river hydrodynamics and sedimentation processes, the radionuclides in bottom sediments have been redistributed. At present, the bottom sediments of the Dnieper reservoirs contain approximately 5,000 and $2,000 \mathrm{Ci}$ of ${ }^{137} \mathrm{Cs}$ and ${ }^{90} \mathrm{Sr}$, respectively. The most contaminated is the Kiev Reservoir, where the maximum contamination level in bottom sediments exceeds $60 \mathrm{Ci} / \mathrm{km}^{2}$ in the upper reservoir near the mouth of the Pripyat River. ${ }^{137}$ Cs contamination of bottom sediments of the Dnieper reservoirs is presented in Table 9. In the future, water contamination levels in the reservoirs

Table 9. Averaged ${ }^{137}$ Cs Contamination in Bottom Sediments of the Kiev, Kanev, Krementchug, and Kakhov Reservoirs in 1987 and $1991^{(a)}$

\begin{tabular}{|l|c|c|}
\hline \multirow{2}{*}{ Dnieper's Reservoirs } & \multicolumn{2}{|c|}{${ }^{137}$ Cs in Bottom Sediments } \\
\cline { 2 - 3 } & 1987 & 1991 \\
\hline Kiev Reservoir & $3580^{(\mathbf{b})}$ & $3000^{(\mathbf{b})}$ \\
\hline \multirow{2}{*}{ Kanev Reservoir } & $3.9^{(\mathrm{c})}$ & $3.5^{(\mathrm{c})}$ \\
\cline { 2 - 3 } & 495 & 830 \\
\hline Krementchug Reservoir & 0.63 & 1.23 \\
\cline { 2 - 3 } & 315 & 580 \\
\hline Kakhov Reservoir & 0.14 & 0.30 \\
\cline { 2 - 3 } & 36 & 180 \\
\hline & 0.04 & 0.08 \\
\hline $\begin{array}{l}\text { (a) Data of Ukrainian Hydrometeorological Institute, Kiev. } \\
\text { (b) The storage of }{ }^{137} \mathrm{Cs} \text { in the bottom deposition }(\mathrm{Ci}) .\end{array}$ \\
(c) The averaged level of ${ }^{137} \mathrm{Cs}$ contamination $\left(\mathrm{Ci}^{2} / \mathrm{km}\right)$. \\
\hline
\end{tabular}


will largely depend on natural hydrologic and human-controlled processes of radionuclide migration. The radionuclide levels will further be controlled by the localization of radioactive elements in the reservoir bottom sediments, by the rate of interphase transformation of the non-exchangeable radionuclide forms into water, and by additional radionuclide influx from contaminated catchment areas. Such additional influx will in turn depend on the efficiency of remediation measures that are being undertaken within the Chernobyl impact area.

\subsubsection{Radionuclide Dynamics During the Floods}

The increase of radionuclide concentrations in the Kiev Reservoir, and subsequent increases in the downstream reservoirs after the initial post-accident period, come from three main sources:

- Radionuclides washing out from the contaminated watersheds of the Dnieper and the Pripyat rivers during snowmelting and heavy rains.

- Washing out of the radionuclides from the highly contaminated area on the Pripyat River floodplain across from the Chernobyl Nuclear Power Plant, especially from the left (east) bank floodplain near Pripyat. This is potentially the greatest source of ${ }^{90} \mathrm{Sr}$ contamination in the Dnieper reservoir system.

- Remobilization of radionuclides from heavily contaminated bottom deposit in the Kiev Reservoir as a result of resuspension or physical-chemical radionuclide transformation processes.

Fluxes from all three of these sources have been correlated with floods on the Pripyat and Dnieper rivers.

The hydrological situation in the Pripyat-Dnieper water system since the 1986 accident has been rather calm. All snow-melt floods have been at or below average levels (probability of occurrence 
exceeding $50 \%$ in one year). The maximum migrations of radionuclides took place during a spring flood in 1987, a summer rainfall-caused flood in 1988, and in the winter of 1991.

The concentration of ${ }^{137} \mathrm{Cs}$ in the Kiev Reservoir during high-flood period increased from the normal $10-15 \mathrm{pCi} / \mathrm{L}$ to $20-40 \mathrm{pCi} / \mathrm{L}$ in 1987 and up to $5 \mathrm{pCi} / \mathrm{L}$ during flooding in 1991 . The concentration of ${ }^{90} \mathrm{Sr}$ had similar trends: high in 1987 and in $1991-1993$. The maximum ${ }^{90} \mathrm{Sr}$ concentration in reservoir water was about 30-40 pCi/L (Figure 9). During major rainfall floods on the Pripyat River (described in Section 2.1.2), it was usual for the ${ }^{90} \mathrm{Sr}$ concentration in the Pripyat River to increase from $10-20 \mathrm{pCi} / \mathrm{L}$ to $30-50 \mathrm{pCi} / \mathrm{L}$ (see Figures 6 and 9). Nonetheless, these rainfall floods did not lead to a significant increase in radionuclide concentrations in the Dnieper reservoirs, because of dilution by water from the Dnieper River. The maximum increase occurred during 1988 rainfall flooding of the Pripyat River, when the concentration of ${ }^{90} \mathrm{Sr}$ in the Kiev Reservoir increased from 8 to $25 \mathrm{pCi} / \mathrm{L}$.

Flooding in the Chernobyl close-in floodplain area had its greatest impact on the contamination of the Dnieper Reservoirs in January 1991. Because of low spring floods, the close-in floodplain area ( $3 \times 15 \mathrm{~km}$ ), which contains more than $8000 \mathrm{Ci}$ of ${ }^{90} \mathrm{Sr}$, had not been flooded since the Chernobyl accident (Figure 12). Simulation of floodplain flow has indicated that the most dangerous situation, which would cause large increases in radionuclide concentrations, is a spring flood with a maximum discharge from 2000 to $3000 \mathrm{~m}^{3} / \mathrm{sec}$ (Zheleznyak et al. 1992c), because during such floods the contaminated floodplain would be completely covered with water. Further increases in water discharge and water elevation in the river are not expected to lead to increases in water contamination because of the further diluting of washed-out radionuclides by the river flow. The probability of floods exceeding (PE) this magnitude for this area of the Pripyat River is $25 \%$ in one year (i.e., this magnitude represents the 4-year flood). During such a spring flood, the water covers all parts of the contaminated floodplain, 


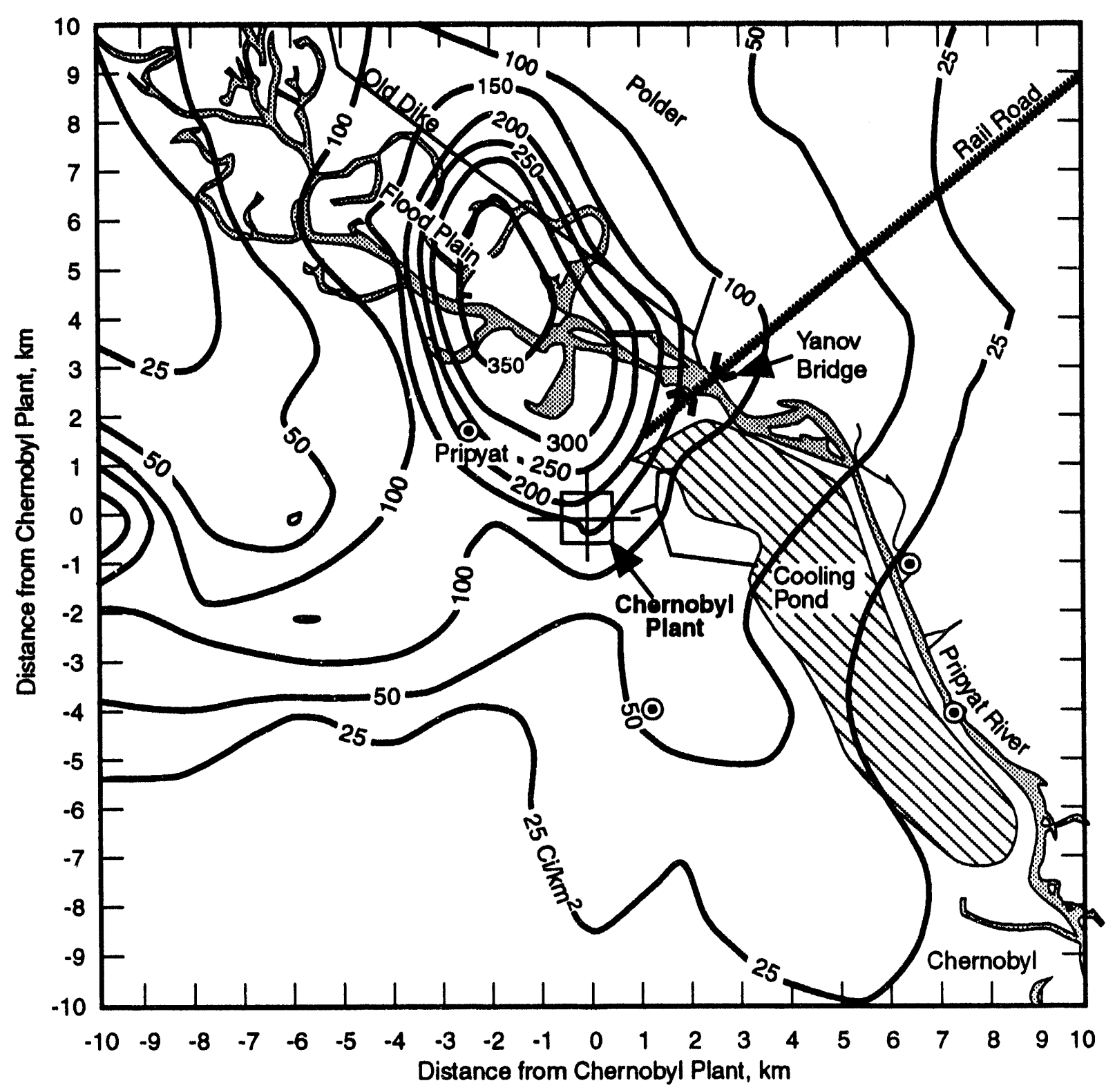

59309086.4

Figure 12. ${ }^{90} \mathrm{Sr}$ Distribution in the Chernobyl Close-in Zone and on the Floodplain Area of the Pripyat River near the Chernobyl Nuclear Power Plant 
but its depth is less than those of higher-PE floods. During flooding of this territory in such hydrological conditions, the ${ }^{90} \mathrm{Sr}$ concentration in the Pripyat water could increase up to $250 \mathrm{pCi} / \mathrm{L}$, exceeding the Ukrainian drinking water standard level for radionuclides $(100 \mathrm{pCi} / \mathrm{L})$. Note that until 1991 , the maximum permissible levels for ${ }^{90} \mathrm{Sr}$ and total ${ }^{134} \mathrm{Cs}$ and ${ }^{137} \mathrm{Cs}$ in drinking water were 400 and $1500 \mathrm{pCi} / \mathrm{L}$, respectively. Since 1991 , new drinking water standards for ${ }^{90} \mathrm{Sr}$ and ${ }^{137} \mathrm{Cs}$ were reduced to 100 and $500 \mathrm{pCi} / \mathrm{L}$, respectively. On the basis of the results of mathematical modeling $u-d$ field investigations, the Ukrainian government decided in September 1990 to construct an earth dike to prevent such flooding. At the time of the flooding in the winter of 1990-1991, only the preparations for construction had been done. The dike was completed at the end of 1992.

In January 1991, extremely low temperatures caused an ice jam to form in the Pripyat River channel between the Yanov Bridge and the town of Chernobyl. As a result, the Pripyat River elevation upstream of the jam increased abruptly, and the Pripyat floodplain near the Chernobyl Nuclear Power Plant was covered by water for the first time since the accident. Due to the water's interaction with the floodplain surface, which was contaminated heavily with ${ }^{90} \mathrm{Sr}$, the concentration of ${ }^{90} \mathrm{Sr}$ in river water near the town of Chernobyl increased from $20 \mathrm{pCi} / \mathrm{L}$ to over $250 \mathrm{pCi} / \mathrm{L}$. The total amount of ${ }^{90} \mathrm{Sr}$ transported by the Pripyat River increased from 0.5 to $10 \mathrm{Ci}$ per day, and the total amount of ${ }^{90} \mathrm{Sr}$ released from the floodplain through the Pripyat River into the Kiev Reservoir during this period exceeded $90 \mathrm{Ci}$.

Fortunately, the impact of this release to the Kiev Reservoir was reduced because of dilution of the Pripyat River water by cleaner Dnieper River water and dispersion of contamination in the reservoir. As a result, the maximum concentration on the way from the Pripyat River mouth to the Kiev Reservoir dam (a distance of more than $80 \mathrm{~km}$ ) diminished from 200 to $30 \mathrm{pCi} / \mathrm{L}$. 


\subsection{Data Collected under Summer Flood Conditions in 1993}

\subsubsection{River Discharge and Water Elevation}

Heavy rainfall on the Belarus and Ukrainian districts of the Pripyat River catchments during July 1993 caused unusually high flooding for the summer period in the upper tributaries of the river basin. Water discharge in the Pripyat River near the Chernobyl Nuclear Power Plant increased from $250 \mathrm{~m}^{3} / \mathrm{s}$ to more than $1200 \mathrm{~m}^{3} / \mathrm{s}$ at the end of August 1993. As a result of runoff flow over the radioactively polluted catchments and washing-out processes, radionuclides from watershed soils flowed down to the surface streams and to the Pripyat River.

The situation on the Dnieper River was less drastic than on the Pripyat. Maximum summer water discharges did not exceed $500 \mathrm{~m}^{3} / \mathrm{s}$, which is rather low for the summer flow rate of the Dnieper River. Therefore, there were no significant changes in water discharges or their radionuclide contamination for the whole summer period on the Dnieper River.

Hydrological data describing the flood situation in the summer of 1993 are presented in Table 10. Supplementary data collected for further model simulation of contaminant fate in the Dnieper cascade include the following:

- water discharge and water elevation information for all tributaries during the period from July 1 to September 1, 1993;

- the operation mode of all dams in the Dnieper reservoir system;

- characterization of suspended matter in river in flows during prior months and the summer flood. 


\subsubsection{Radioactive Contamination of the Pripyat/Dnieper System}

Due to flooding of contaminated territories of the Pripyat River channel and increased washing out from the watersheds during rainfall, ${ }^{90} \mathrm{Sr}$ concentrations in the Pripyat River increased in the first weeks of the flood. Near the Chernobyl area, the maximum ${ }^{90} \mathrm{Sr}$ concentration in Prif yat River water was about $20-25 \mathrm{pCi} / \mathrm{L}$ in early August; near the Pripyat River mouth, the concentration was elevated to $35 \mathrm{pCi} / \mathrm{L}$. The peak concentration of ${ }^{90} \mathrm{Sr}$ in the water of small rivers inside the $30-\mathrm{km}$ zone was sharper, reflecting an increase to $60-70 \mathrm{pCi} / \mathrm{L}$ from $15-20 \mathrm{pCi} / \mathrm{L}$ before the flood. Before the flood, the ${ }^{90} \mathrm{Sr}$ concentration in the Kiev Reservoir was in the range 7-10 $\mathrm{pCi} / \mathrm{L}$ and that in the Kanev Reservoir was 3-5 pCi/L. The ${ }^{90} \mathrm{Sr}$ concentration in the water at the mouth of the Dnieper River has not exceeded 6-8 $\mathrm{pCi} / \mathrm{L}$.

The ${ }^{137} \mathrm{Cs}$ concentration in the Pripyat River did not increase significantly, and ${ }^{137} \mathrm{Cs}$ concentrations in water across from the Chernobyl site did not exceed 5-7 $\mathrm{pCi} / \mathrm{L}$. At the first stage of flooding in the Pripyat River in the middle of July, ${ }^{137} \mathrm{Cs}$ concentrations in water of the Kiev Reservoir were 2-5 $\mathrm{pCi} / \mathrm{L}$. In water of the Kanev Reservoir, the ${ }^{137} \mathrm{Cs}$ concentrations were $1-3 \mathrm{pCi} / \mathrm{L}$. More detailed information for radionuclide concentration during the summer of 1993 is given in Table 10. 
Table 10. Water Discharge $\left(\mathrm{m}^{3} / \mathrm{s}\right)$ and ${ }^{90} \mathrm{Sr}$ and ${ }^{136} \mathrm{Cs}$ Contents $(\mathrm{pCi} / \mathrm{L})$

\begin{tabular}{|c|c|c|c|c|c|c|c|c|c|c|}
\hline \multirow[b]{2}{*}{ Davo } & \multicolumn{2}{|c|}{ Prip.cher } & \multicolumn{2}{|c|}{ Dnic. Nedch } & \multicolumn{2}{|c|}{ Kroles } & \multirow{2}{*}{$\begin{array}{l}\text { Dam Int } \\
\text { Diecharge }\end{array}$} & \multirow{2}{*}{$\begin{array}{l}\text { Knnying } \\
\text { Dicoharge }\end{array}$} & \multicolumn{2}{|c|}{ Kromonthur me } \\
\hline & Discharged & 90 & Diecharged & $\log _{\mathrm{g}}$ & Diecharg & & & & Diecharged & ${ }^{137} \mathrm{Cu}^{*}$ \\
\hline JuI 1293 & 240 & 15 & $3 \%$ & 5 & 682 & 8 & 205 & 835 & 1500 & 7.610.5 \\
\hline Jul 1393 & 245 & & 392 & & 792 & & 208 & 901 & 1490 & \\
\hline Jul 1493 & 245 & & $3 \%$ & & 735 & & 213 & 959 & 790 & \\
\hline Jul 1593 & 245 & & 400 & & 737 & & 217 & 937 & 1070 & $2.0 / 0.3$ \\
\hline Jul 1693 & 250 & & 706 & & 742 & & 217 & 881 & 631 & \\
\hline Jul 1793 & 250 & & 410 & & 419 & & 219 & 397 & 344 & \\
\hline Jul 1893 & 260 & & 414 & & 322 & & 222 & 296 & 383 & \\
\hline Jul 1993 & 265 & & 717 & & 792 & & 224 & 950 & 1050 & \\
\hline Jul2093 & 270 & 19 & 420 & 6 & 887 & 9 & 226 & 1200 & 841 & $8.6 / 1.0$ \\
\hline Jul 2193 & 285 & & 450 & & 962 & & 228 & 1230 & 788 & \\
\hline Jul 2293 & 300 & & 300 & & 1200 & & 235 & 1590 & 1350 & \\
\hline Jul 2393 & 320 & & 340 & & 1410 & & 233 & 1770 & 1120 & \\
\hline Jul 2493 & 355 & & 380 & & 1038 & & 237 & 1300 & 635 & \\
\hline JuI 2593 & 375 & 18 & 600 & 6 & 612 & 10 & 236 & 850 & 313 & \\
\hline Jul 2693 & 410 & & 630 & & 1200 & & 238 & 1470 & 1160 & \\
\hline Jul 2793 & 430 & & 665 & & 1220 & & 235 & $13 \%$ & 1350 & \\
\hline Jul 2893 & 460 & & 690 & & 1640 & & 233 & 1740 & 1460 & \\
\hline Jul 2993 & 305 & 22 & 700 & 8 & 1730 & 10 & 232 & 2090 & 1090 & $4.5 / 1.7$ \\
\hline Jul 3093 & 380 & 27 & 710 & 7 & 2180 & $\pi$ & 233 & 2310 & 1980 & $3.6 / 1.2$ \\
\hline Jul 3193 & 650 & 26 & 670 & & 2410 & 9 & 232 & 3380 & 1340 & $6.3 / 2.4$ \\
\hline Aug 0193 & 690 & 25 & 650 & & 2370 & 9 & 228 & 2610 & 626 & \\
\hline Aug 0293 & 720 & 23 & 640 & & 2440 & 12 & 228 & 1270 & 1250 & \\
\hline Aug 0393 & 743 & 27 & 620 & 7 & 1460 & 11 & 2288 & 1340 & 1700 & 6.011 .7 \\
\hline Aus 0493 & 780 & 26 & 610 & & 1470 & & 228 & 2040 & 1500 & 4.711 .2 \\
\hline Aug 0593 & 775 & & 600 & & 1610 & & 225 & 2030 & 2030 & \\
\hline Aug 0693 & 790 & & 590 & & 1580 & & 222 & 1830 & 2260 & \\
\hline Aug 0793 & 810 & & 570 & & 1290 & & 218 & 1240 & 826 & \\
\hline Aug 0893 & 825 & & 550 & & 1170 & & 218 & 1280 & 1270 & \\
\hline Aug 0993 & 870 & & 325 & & 1532 & & 224 & 1870 & 2000 & \\
\hline Aug 1093 & 840 & 20 & 510 & & 1470 & & 232 & 1750 & 1810 & $5.6 / 1.3$ \\
\hline Aug 1193 & 850 & & 505 & 5 & 1150 & & 236 & 1240 & 1880 & \\
\hline Aug 1293 & 900 & 17 & 500 & & 1180 & & 238 & 1450 & 1570 & \\
\hline Aug 1393 & 950 & & 495 & 6 & 1178 & & 240 & 1630 & 1290 & \\
\hline Aug 1493 & 1000 & & 487 & & 1364 & & 240 & 1640 & 1440 & \\
\hline Aug 1592 & 1050 & 19 & 480 & 6 & 1327 & & 244 & 1660 & 1060 & \\
\hline Aug 1693 & 1075 & & 473 & & 1580 & & 250 & 1640 & 1830 & \\
\hline Aug 1793 & 1100 & & 466 & & 1580 & & 256 & 1550 & 1810 & \\
\hline Aug 1893 & 1120 & 18 & 468 & & 1350 & & 258 & 1560 & 1740 & \\
\hline Aug 1993 & 1140 & & 465 & & 1300 & & 260 & 1670 & 2590 & \\
\hline Aug 2093 & 1180 & & 460 & & 1400 & & 262 & 1290 & 1640 & \\
\hline Aug 2193 & 1200 & 17 & 455 & & 1320 & & 262 & 1520 & 1360 & \\
\hline Aug 2293 & 1200 & & 450 & 4 & 1240 & & 264 & 1330 & 1140 & \\
\hline Aus 2393 & 1450 & 18 & 440 & 4 & 1215 & & 278 & 1330 & 1440 & \\
\hline Aug 2493 & 1120 & & 433 & & 1245 & & 278 & 1340 & 940 & \\
\hline Aug 2593 & 1100 & & 425 & & 1240 & & 280 & 1530 & 1960 & \\
\hline Aug 2693 & 1050 & & 423 & & 1370 & & 282 & 1800 & 1610 & \\
\hline Aug 2793 & 1000 & & 422 & & 1470 & & 282 & 1790 & 1740 & \\
\hline Aug 2893 & 950 & & 422 & & 1520 & & 282 & 1580 & 1480 & \\
\hline Aug 2993 & 920 & 15 & 425 & & 1400 & & 280 & 1690 & 1050 & \\
\hline
\end{tabular}




\subsection{Radionuclide Transport Modeling}

\subsection{Applied Models and Methodology}

A system of computer models of radionuclide transport in the Pripyat River and the Dnieper reservoirs was developed and has been used at the Cybernetics Center of the Ukrainian Academy of Sciences, Kiev, since 1986 (Mikhalevich et al. 1987; Zheleznyak 1990; Zheleznyak et al. 1992a,b,c, 1993). The system, which is based on various mathematical models and data banks, has been refined in close collaboration with specialists from the Ukrainian Hydrometeorological Institute, SPA Typhoon, and other institutions. The approaches and methods used in the Ukrainian modeling of major processes are based on those developed at PNL (Onishi 1981; Onishi et al. 1982, Onishi and Trent 1985; Onishi and Thompson 1986).

The main purposes of developing the model system are as follow:

- predicting radionuclide transport in surface-water bodies,

- performing a detailed analysis of water and sediment contamination in selected rivers and reservoirs,

- estimating the efficiency of special hydraulic countermeasures designed to decrease the rate of radionuclide outflow from the Pripyat River and the Kiev Reservoir (e.g., bottom traps for contaminated sediments, dikes in floodplain, and underwater dams in reservoirs), and

- supporting the plans for Dnieper reservoir operation on the basis of optimization models that account for water pollution.

To accommodate the broad temporal and spatial scales being considered, a hierarchy of radionuclide transport models was developed (Zheleznyak 1990; Zheleznyak et al. 1992a,b,c). Hydrologic and water pollution databases were generated to support the modeling system. 
The modeling of radionuclide transport in rivers and river-run reservoirs has some special characteristics. Radionuclide migration in rivers and reservoirs is affected by high flow velocities, short retention times, and large variability in water discharge during a year; since a large portion of the radionuclides are sorbed to sediment, radionuclide distributions are subject to large temporal and spatial variations in sedimentation and resuspension rates. Other processes that are important to rivers and reservoirs are channel flow and floodplain interactions during floods, the strong impacts of the hydraulic structures on flow parameters, and rs id water level changes caused by reservoir management. These differences necessitate the use of special approaches for modeling radionuclide transport in river/reservoir systems. Some of these modeling methods have been reviewed by Onishi et al. (1981), Codell et al. (1982), and Santschi and Honeyman (1989).

The river/reservoir models require several kinds of submodels: hydraulics submodels to describe the water, suspended sediment, and bottom sediment dynamics; and radionuclide submodels to examine the fate of radionuclides in different phases driven by these hydraulic processes.

The hydraulics submodels include mathematical descriptions of the following processes:

- wind circulation, including seiches and circulation driven by inflow/outflow currents;

- turbulent transport;

- suspended sediment transport;

- sedimentation and resuspension;

- wind-caused wave propagation and transformation; ${ }^{(a)}$

(a) Processes may be important for reservoirs only. 
- wave-driven nearshore circulation;(^) ${ }^{(a)}$

- dynamics of temperature and density stratification. ${ }^{(a)}$

For long-term projections, precipitation and evaporation may also be taken into account, as well as water losses due to irrigation and industrial and municipal use.

The fate of radionuclides in general is simulated using the following types of submodels:

- a dissolved contaminant transport submodel;

- a particulate contaminant transport submodel; this may also include a separate description of contaminants transported by different types of sediment (e.g., clay, silt, mud and sand grains);

- a submodel that estimates the contamination dynamics in the active upper layer of bottom sediments;

- a submodel of contamination dynamics in deeper buried sediment layers;

- a submodel of contaminant transfer in interstitial waters;

- a submodel of contaminant transfer by bioturbation in bottom sediments; and

- a submodel of contaminant transfer by biota.

Modeling the transport and fate of the radionuclides in three different phases (radionuclides in solution, in suspended sediment, and in bottom sediments) is particularly important. Some suitable approaches for simulation of radionuclide dispersion have been developed by Onishi for one(Onishi et al. 1982), two- (Onishi 1981; Onishi et al. 1982), and three-dimensional models (Onishi and Trent 1985; Onishi et al. 1993) and by Booth (1975) and Schuckler et al. (1976) for fully mixed box models. 
The Pripyat-Dnieper system includes various types of water bodies, ranging from large rivers with their tributaries and floodplains to large reservoirs. The temporal and spatial scales of the processes under consideration may increase by more than two orders of magnitude when different modeling objects are considered. It is clear that no single model could describe such a wide range of processes satisfactorily. Therefore, a hierarchy of mathematical models of radionuclide dispersion that describes these processes has been developed by averaging the primitive three-dimensional equations over the spatial variables (Zheleznyak 1990; Zheleznyak et al. 1992a,b). All of the models account for the fate of the radionuclides in all three phases (radionuclides in solution, in suspended sediments, and in bottom sediment), as well as describing absorption-desorption and sedimentation-resuspension processes.

The contamination exchanges between water, sediment, and bottom deposition are described using the distribution coefficient, $K_{d}$, which is the ratio between contamination on particles and solution under equilibrium conditions. The other parameters used are radionuclide transfer rate coefficients, a, which are determined by the characteristic time of transfer between dissolved and sediment-sorbed radionuclides. The main factors affecting the sediment-contamination interaction are taken into account when the $K_{d}$ is considered as a function of water quality, geochemical properties of the sediments, physical-chemical forms of radionuclides, sediment concentration, and so on (Onishi et al. 1981; Santschi and Honeyman 1989).

Using this approach, the description of the physical-chemical behavior of the radionuclides has been linked with the characteristics of the Chernobyl accident. More complicated radionuclide transfer submodels that distinguish the different kinds of physical-chemical forms of radionuclides in the solid phase (exchangeable and non-exchangeable forms) have been developed (Borzilov et al. 1989; 
Konoplev et al. 1992). This more complicated approach requires detailed experimental data, which, as a rule, cannot be obtained without careful site-specific field investigations. It is only recently that the necessary data for the Pripyat-Dnieper system are being collected.

In the Cybernetics Center's modeling system, four models are used, depending on the spatial or temporal scale of interest (Zheleznyak et al. 1993). WATOX is a box model used to examine radionuclide dispersion in the large reservoirs. RIVTOX is a one-dimensional model used to examine processes in the rivers and estuaries. COASTOX is a two-dimensional lateral-longitudinal model designed to represent the reservoirs and floodplains. And finally, VERTOX is a two-dimensional vertical-longitudinal model designed to examine fine sediment-radionuclide interaction processes in the vicinity of hydraulic constructions designed as countermeasures, such as bottom sediment traps and dams. Each model is briefly discussed below. Details about WATOX are provided in the Appendix.

\subsubsection{WATOX - Boz Model}

The WATOX computer code is a realization of the box-type (i.e., compartmentally averaged) model based on the set of ordinary differential equations describing water, sediment, and radionuclide transport.

Box models represent a reservoir as one or more compartments (boxes) in which water quality parameters are homogeneous. The models assume that the contaminated water discharged into the compartment is instantaneously mixed with the water already present. Therefore, the contaminant concentration in the outflow is identical with that in the compartment. The model variables are the 
compartment's volume, the suspended sediment concentration, and the concentrations of the radionuclide in solution, suspended sediments, and bottom deposition. The numerical solutions of model equations are obtained by the Runge-Kutta method.

WATOX has been the main tool for forecasting radionuclide dispersion in the Dnieper reservoirs during the spring flood periods, which last 3-4 months and more. Optimization methods are used to choose the reservoir system operation mode under the water quality criteria for the simulation period. Dissolved contamination, contamination on sediments, and contamination within the bottom sediments are considered, with a special treatment of contamination-sediment interaction. The parameterization of this processes is similar to the one used by Schuckler et al. (1976), but additional processes are included, as well as a supplementary submodel used to simulate temporal variations in the sedimentation and resuspension rates during flood propagation in the reservoirs. Model testing has shown the significance of this mechanism for the f- of ${ }^{137} \mathrm{Cs}$ in the reservoirs.

\subsubsection{RIVTOX - One-Dimensional Channel Model}

One-dimensional models describe the cross-sectionally averaged flow and contamination parameters in channels. The one-dimensional model RIVTOX was developed by averaging the two-dimensional COASTOX mode equations over the channel width. The one-dimensional Saint-Venant's equations and advection-dispersion equations with source terms are used to simulate the flow, suspended sediments, and radionuclide transport both in solution and in suspended sediments. The implicit finite-difference scheme used for numerical solution of the Saint-Venant's equations permits the simulation of flow in a channel network with relatively large time steps. The splitting method, with a 
Holly-Preissmann fourth-order finite-difference scheme on the advection step, can be used to diminish the numerical diffusion in the advection-dispersion equations.

\subsubsection{COASTOX - Two-Dimensional Lateral-Longitudinal Model}

Two-dimensional lateral-longitudinal models are widely used to simulate pollutant flow and dispersion in shallow reservoirs, floodplains, and coastal waters. The model equations can be derived by averaging the primitive three-dimensional equations over the depth of the water body. Equations of this type have previously been used in the FETRA code to simulate radionuclide dispersion in coastal areas (Onishi and Thompson 1986). The COASTOX model, which was developed in the Cybernetics Center to simulate pollutant dispersion in the Dnieper reservoirs and in the Pripyat River (Zheleznyak et al. 1982b, 1993), contains radionuclide transport submodels similar to the ones used in FETRA. However, in COASTOX, other approaches are used for modeling suspended sediment transport and wind wave effects. Finite-element and finite-difference methods are combined to solve the model's equations.

\subsubsection{VERTOX - Two-Dimensional Vertical-Longitudinal Model}

The model VERTOX was derived from three-dimensional models of hydraulic and pollutant transport processes by averaging the equations over the flow width, resulting in a two-dimensional verticallongitudinal model (Zheleznyak et al. 1993). This approach has previously been used for the simulation of radionuclides in the SERATRA code at PNL (Onishi et al. 1981). The main objects of the VERTOX application are zones where abrupt changes in the flow parameters occur. An important 
example of such a zone is flow at the bottom sediment traps designed to settle the contaminated suspended sediments in the Pripyat River channel.

The flow-governing equations are derived using a hydrostatic approximation. The advection-diffusion equation for suspended sediment transport is used to describe the sediment deposition and erosion rates. The submodel for radionuclide transport describes the radionuclide concentration in solution, the concentration in the suspended sediments, and the concentration in the bottom deposits. The exchanges between these forms are adsorption-desorption and sedimentation-resuspension processes.

\subsection{Modeling of the Pripyat River Floodplain}

As described in Chapter 2.0, one of the most significant radionuclide sources of radioactive contamination in the Pripyat River and thus the Dnieper River is the fuel particles resulting from fallout onto the Pripyat River floodplain across from the Chernobyl Nuclear Power Plant. The poten:flooding of this territory has been simulated using the COASTOX (WATOX-2) computer code (Zheleznyak and Voitsekhovitch 1991; Zheleznyak et al. 1992b). As described above, this territory had not been flooded since the 1986 Chernobyl accident until 1991 because spring floods have been low. During flooding of this floodplain, the most critical source of radionuclide contamination in water is ${ }^{90} \mathrm{Sr}$ deposited in the floodplain. Because of the relatively low distribution coefficient $\left(\mathrm{K}_{d}\right)$ for ${ }^{90} \mathrm{Sr}$, sediment-water interactions do not significantly impact ${ }^{90} \mathrm{Sr}$ migration within surface water. In such a 
situation, the governing parameters of the model are the $K_{d}$ and the rate of radionuclide exchange between water and bottom sediments $\left(A_{1,3}\right)$. To obtain these parameters, special laboratory measurements were made by the Ukrainian Hydrometeorology Institute (Voitsekhovitch et al. 1993a,b). Soil samples from the floodplain were covered with water, and the subsequent changes in ${ }^{90} \mathrm{Sr}$ concentrations in the water and soil were measured. On the basis of these data, $K_{d}$ and $\left(A_{1,3}\right)$ values were determined.

Simulation of floodplain flow has demonstrated that the most dangerous situation, which would cause large increases in radionuclide concentrations, is a spring flood with a maximum discharge of $2000 \mathrm{~m}^{3} / \mathrm{sec}$. The probability of exceeding (PE) this flood magnitude for the area of the Pripyat River is $25 \%$. During such a spring flood, water covers all parts of the contaminated floodplain, as in the simulated flow field shown in Figure 13.

For those simulations, it was assumed that the depth-averaged concentration of ${ }^{90} \mathrm{Sr}$ at the upstream boundary equals $50 \mathrm{pCi} / \mathrm{L}$. This level of ${ }^{90} \mathrm{Sr}$ in the Pripyat River water would result from radionuclides washing out from the upstream watersheds. As shown in Figure 14, due to the desorption of ${ }^{90} \mathrm{Sr}$ from the floodplain sediment, the computed ${ }^{90} \mathrm{Sr}$ concentration in water increases by more than four times from inflow to outflow boundaries. The computed time for water to travel between these boundaries is 12 hours. 


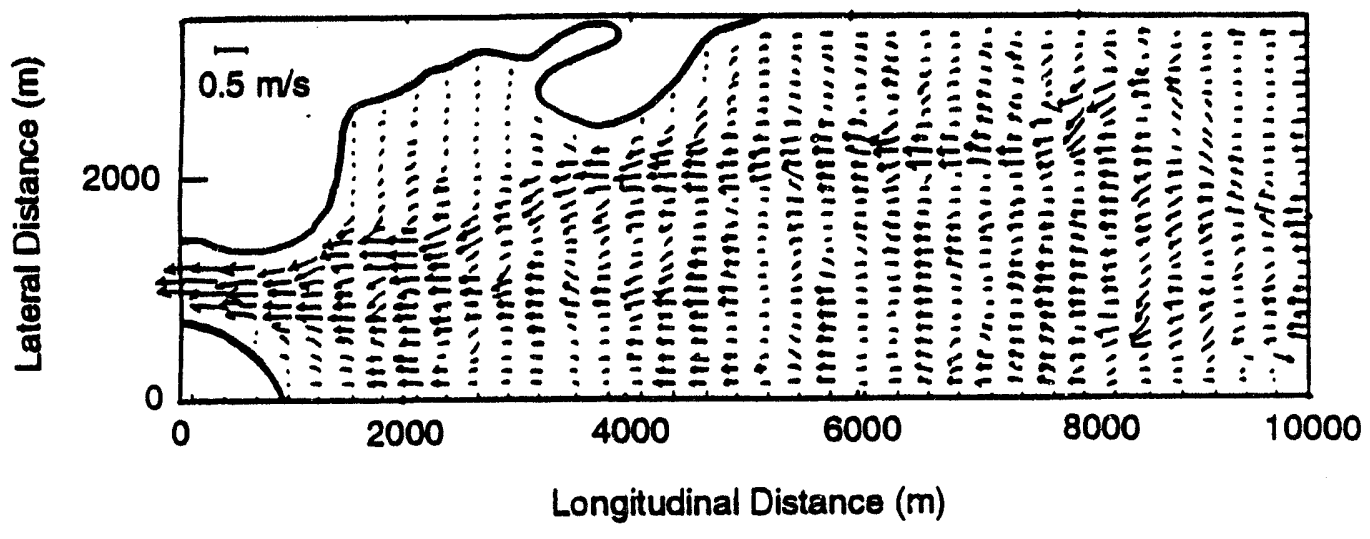

Figure 13. Predicted Depth-Averaged Velocities on the Pripyat River Floodplain During a 25\% PE Spring Flood

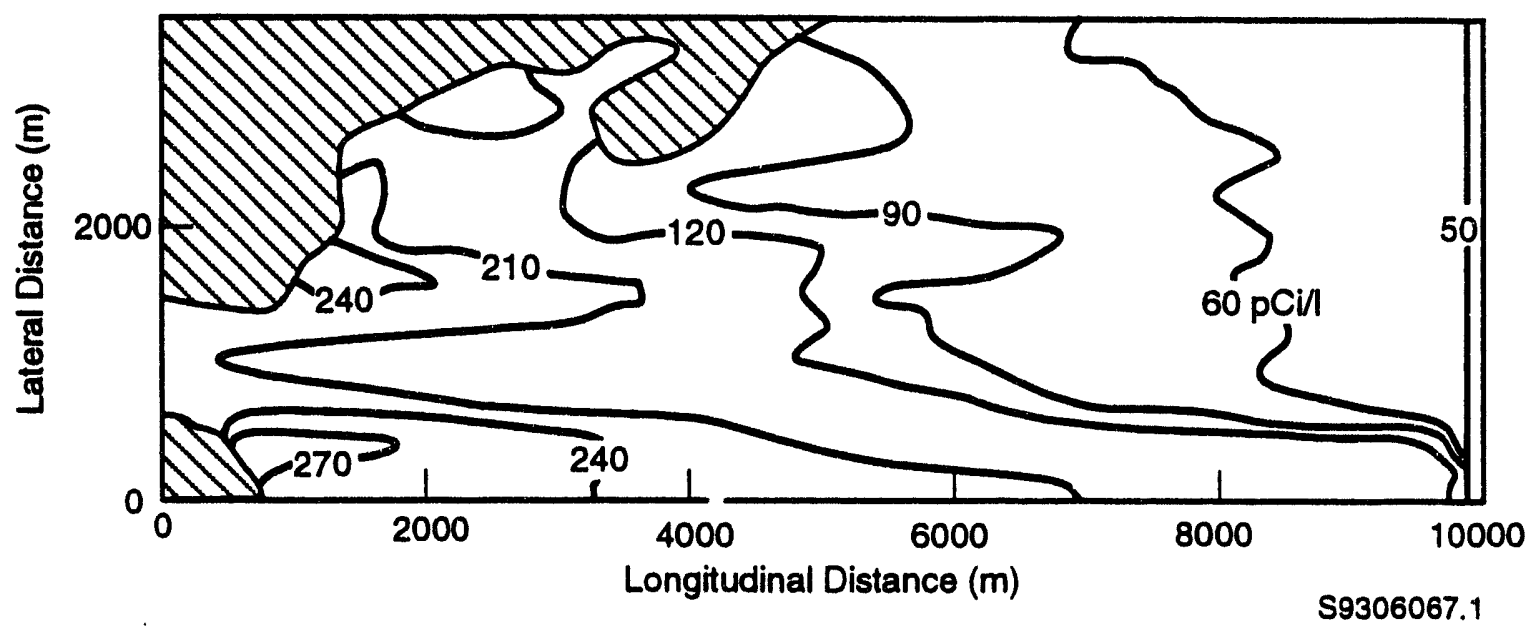

Figure 14. Predicted Depth-Averaged ${ }^{90} \mathrm{Sr}$ Concentration (-) $\left(\mathrm{PCil}^{-1}\right)$ and Depth Isolines (m) (---) During a 25\% PE Spring Flood 
The highest simulated flood $(P E=1 \%)$ has a maximum discharge of $6000 \mathrm{~m}^{3} / \mathrm{sec}$. For such a discharge, the computed travel time is five hours, and the maximum ${ }^{90} \mathrm{Sr}$ concentration at the downstream boundary is $60 \mathrm{pCi} / \mathrm{L}$. This increase in concentration above the bottom contaminated area is small compared to that for the flood with the maximum discharge of $2000 \mathrm{~m}^{3} / \mathrm{s}$ because of the decrease in travel time and an increase in the water discharge and depth.

The computed results showing a significant increase in ${ }^{90} \mathrm{Sr}$ concentration in the Pripyat River during the flooding have stimulated the search for effective countermeasures. Several approaches have been proposed, and the potential effectiveness of each for reducing radionuclide concentrations in the Pripyat River has been evaluated through modeling. The creation of an earthen dike around the contaminated area, on the left (east) bank of the Pripyat River across from the Chernobyl Nuclear Power Plant, has been chosen as the best countermeasure. The predicted flow pattern with the dike installed is presented in Figure 15. This measure, supplemented by decontamination of soil on the right bank, could diminish the ${ }^{90} \mathrm{Sr}$ concentration at the downstream boundary to nearly the same level as at the upstream boundary. The simulated radionuclide distribution for this scenario is shown in Figure 16. The decision to construct such a dike was made in 1990.

In January 1991, before the starting of dike construction, an ice jam formed in the Pripyat River channel between the Yanov Bridge and the town of Chernobyl. The Pripyat River water elevation upstream of the jam increased rapidly. As a result, the Pripyat floodplain near the Chernobyl Nuclear Power Plant was covered by water for the first time since the 1986 accident. (The hydrological and radiological data for this case have been presented in Section 2.1.6.) 


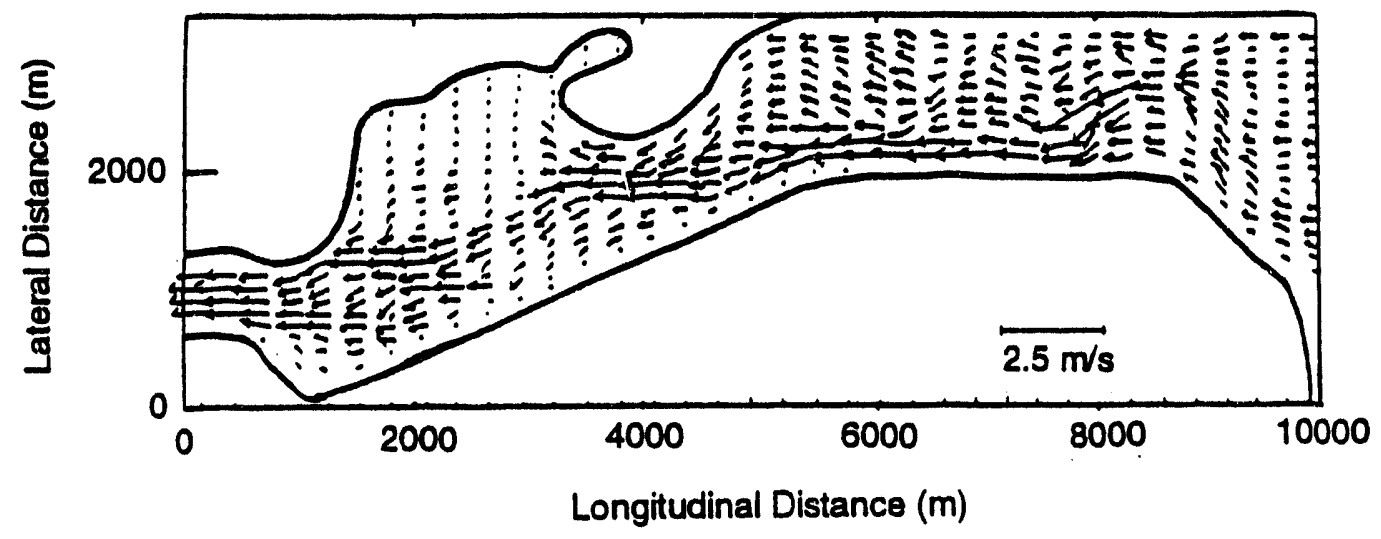

Figure 15. Predicted Depth-Averaged Velocities During the Same Flood as Presented in Figure 13 after Construction of the Dike

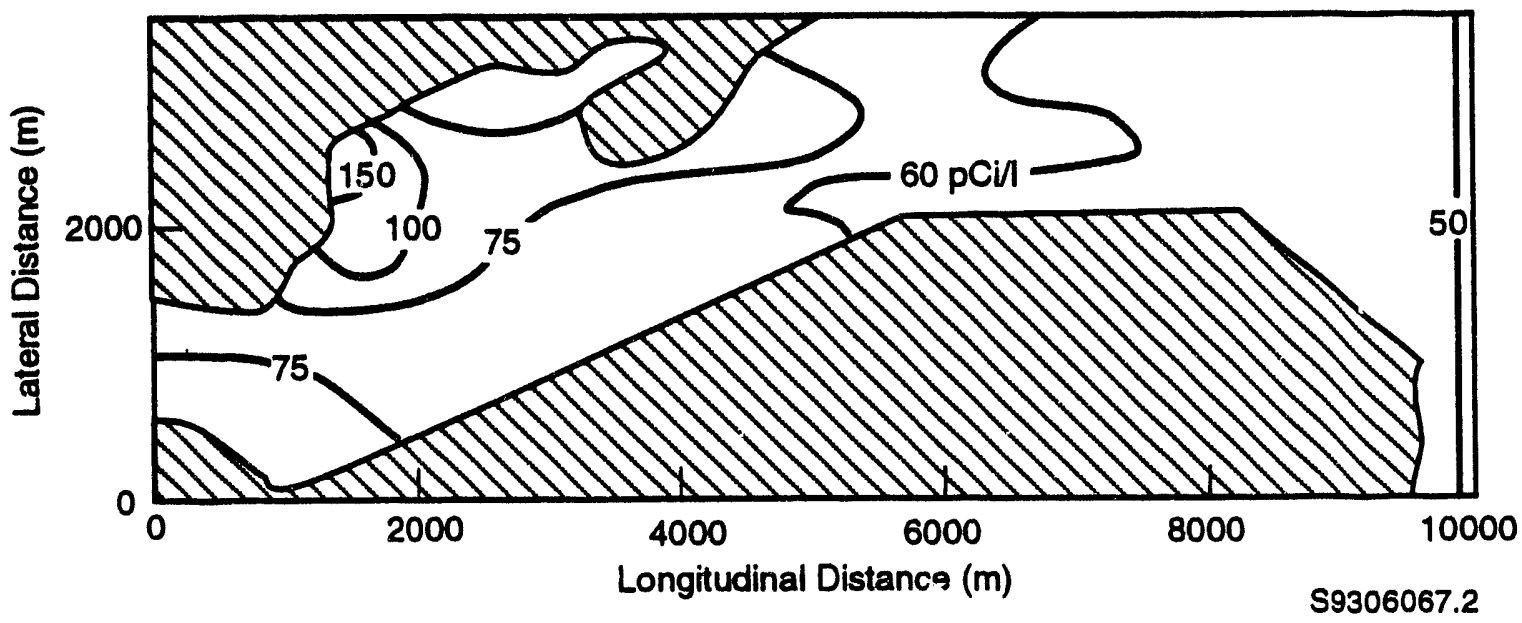

Figure 16. Predicted Depth-Averaged ${ }^{90} \mathrm{Sr}$ Concentration During the Same Flood as Presented in Figure 13 after Construction of the Dike 
During this flood, measured ${ }^{90} \mathrm{Sr}$ concentrations in Pripyat River water near the Yanov Bridge increased to 250 to $300 \mathrm{pCi} / \mathrm{L}$. This level is very close to simulated values for the $25 \% \mathrm{PE}$ flood, thus confirming the simulation results.

The Cybernetics Center's modeling system was then used to simulate ${ }^{90} \mathrm{Sr}$ propagation in the Kiev Reservoir and to predict radionuclide concentrations in the Dnieper River near Kiev. Dilution and dispersion of contamination in the Kiev Reservoir reduced the maximum predicted ${ }^{90} \mathrm{Sr}$ concentration from $200 \mathrm{pCi} / \mathrm{L}$ at the mouth of the Pripyat River to $30 \mathrm{pCi} / \mathrm{L}$ at the Kiev Hydropower Plant (more than $60 \mathrm{~km}$ downstream at the downstream end of the Kiev Reservoir) (Figure 17). This forecast, which was confirmed later by field measurements, was provided to the Ukrainian government. Such timely information on when and how strontium concentrations in the Dnieper's water near Kiev would increase allowed the government commission to change the municipal water supply arrangements in February 1991 to avoid use of Dnieper River water. The dike to prevent future flooding of this territory was completed before the 1992 spring flood.

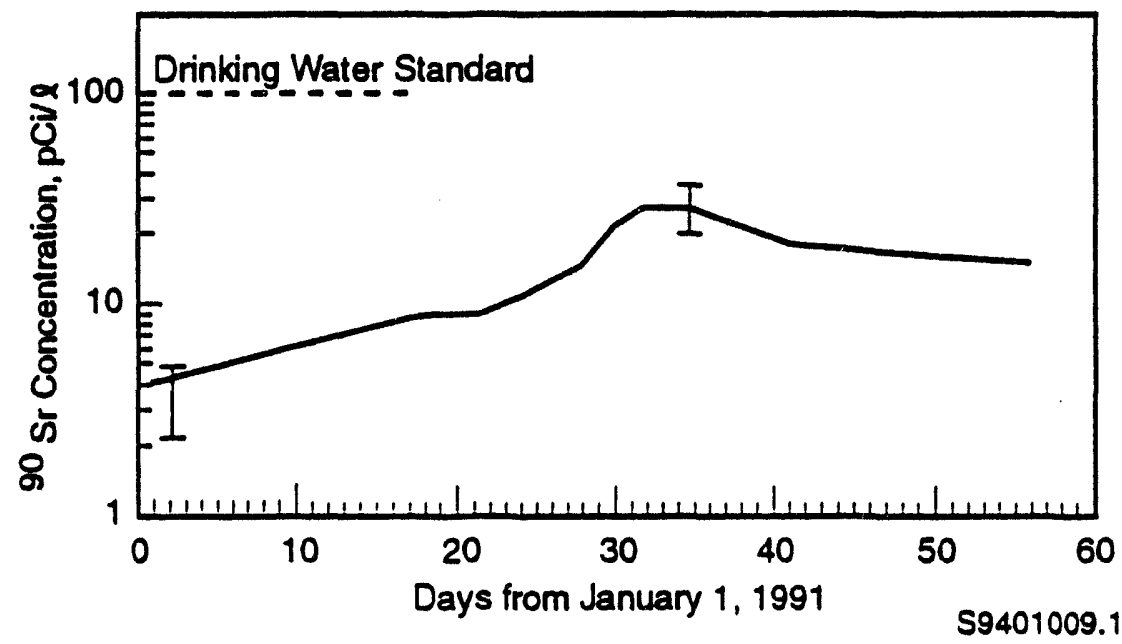

Figure 17. ${ }^{90} \mathrm{Sr}$ Concentrations Near Kiev Hydropower Plant (Downstream end of the Kiev Reservoir) Since January 1, 1991 


\subsection{Modeling of Dnieper River Reservoirs}

Each year since the accident, forecasts of ${ }^{137} \mathrm{Cs}$ and ${ }^{90} \mathrm{Sr}$ concentrations in the Dnieper reservoirs during spring flood (March-June) have been prepared in February or March. The basis for their development has been forecasts of spring runoff volume and maximum discharge prepared by the Ukrainian State Hydrometeorological Committee. The data on contamination distribution in the watershed and the averaged values of the radionuclide washoff coefficients were used to predict ${ }^{137} \mathrm{Cs}$ and ${ }^{90} \mathrm{Sr}$ dynamics in the tributaries that discharge into the reservoirs. The computed results show that the total amount of ${ }^{90} \mathrm{Sr}$ that might be washed out of the $60 \mathrm{~km} \mathrm{x} 60 \mathrm{~km}$ zone around the Chernobyl Nuclear Power Plant during a 50\% PE spring flood equals $270 \mathrm{Ci}$; the amount for a $25 \% \mathrm{PE}$ flood is $460 \mathrm{Ci}$, that for a $10 \% \mathrm{PE}$ flood is $670 \mathrm{Ci}$, and that for a $1 \% \mathrm{PE}$ flood is $1240 \mathrm{Ci}$.

A small amount of ${ }^{90} \mathrm{Sr}$ is continuously being washed out from the watersheds with sediments $(6 \%-8 \%)$. On the other hand, more than $85 \%$ of ${ }^{137} \mathrm{Cs}$ is transported from watersheds by the erosion of sediments. This ratio changes in the water bodies. In the rivers and reservoirs, $20 \%$ to $50 \%$ of ${ }^{137} \mathrm{Cs}$ is carried out by suspended sediments.

An example of the predicted concentration of ${ }^{137} \mathrm{Cs}$ in the Dnieper reservoirs is presented in Figure 18. Comparison of the simulated results with data measured during the 1993 flood by the Ukrainian Ministry of Water Management, Ministry of Health, and Hydrometeorological Committee demonstrates a reasonable agreement for the contamination concentrations and trends. The predicted increase in ${ }^{137} \mathrm{Cs}$ concentration level in the Kiev Reservoir and the Kakhovka Reservoir is more than an order of magnitude. This increase is a result of contamination-sediment interaction, a very important 


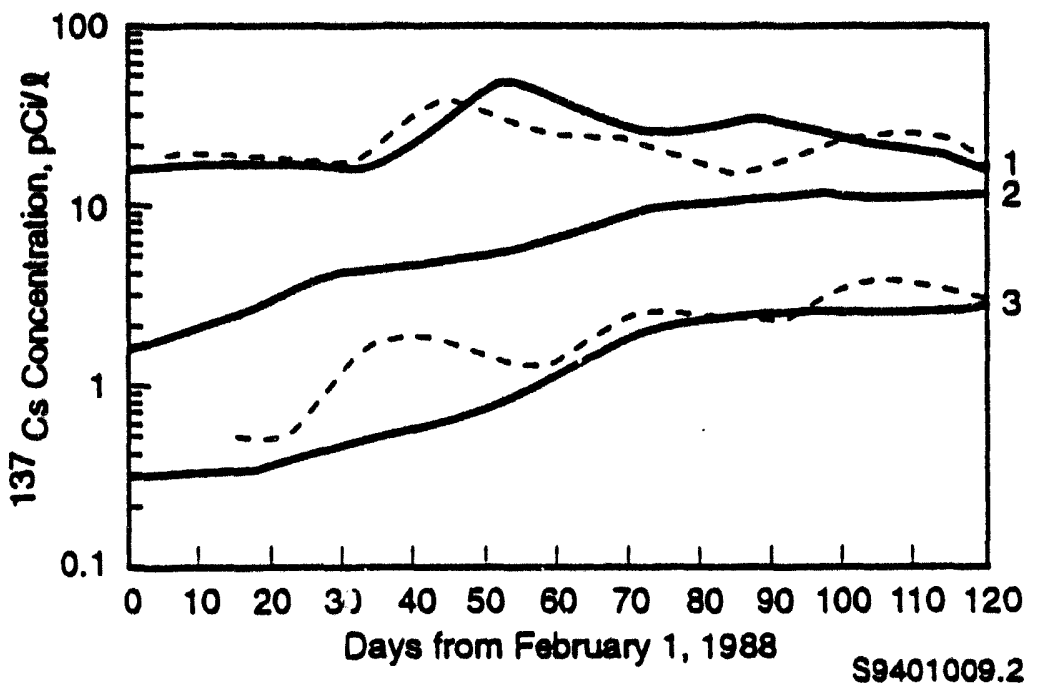

Figure 18. Predicted ${ }^{137}$ Cs Concentrations in the Dnieper Reservoirs During the 1988 Spring Flood. Predicted (-) and Measured data (-). Time, days elapsed from 1 February 1988.

(1) Kiev Reservoir, northern part; (2) Dnieprodzerzhins Reservoir;

(3) Kakhovka Reservoir.

mechanism for dispersion of cesium in water bodies. Therefore, a high value for the distribution coefficient should be used for successful description of ${ }^{137} \mathrm{Cs}$ transport $\left(\mathrm{K}_{\mathrm{d}}=5000 \mathrm{~L} / \mathrm{kg}\right.$ for simulated results in Figure 18).

Since 1988, the ${ }^{137} \mathrm{Cs}$ concentration in the Dnieper reservoirs has decreased due to the low discharges of the 1989-1993 spring floods and the diminishing of the ${ }^{137} \mathrm{Cs}$ washoff coefficient from the watersheds. However, the coefficient of ${ }^{90} \mathrm{Sr}$ washoff has not diminished in the same manner. Therefore, ${ }^{90} \mathrm{Sr}$ contamination is a more significant problem for the high spring floods in the Pripyat River watersheds. The simulation of processes on the floodplain described above has therefore been supplemented by forecasting of ${ }^{90} \mathrm{Sr}$ dispersion in the Dnieper reservoirs. 
The results of the simulation of 25\% PE flood on the Dnieper reservoir system are shown in Figure 19 for conditions before and after dike construction. For the after-dike simulation, only contamination discharged from watersheds was taken into account for the Pripyat River inflow into the reservoir. Overall, the predicted maximum ${ }^{90} \mathrm{Sr}$ concentration in the Kiev Reservoir is $150 \mathrm{pCi} / \mathrm{L}$ without the dike (higher than Ukrainian radiological standard of $100 \mathrm{pCi} / \mathrm{L}$ for drinking water) and $50 \mathrm{pCi} / \mathrm{L}$ with the dike (lower than the Ukrainian radiological standard for drinking water). 


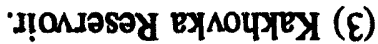

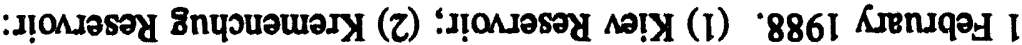

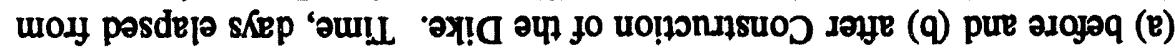

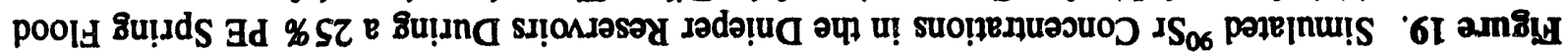
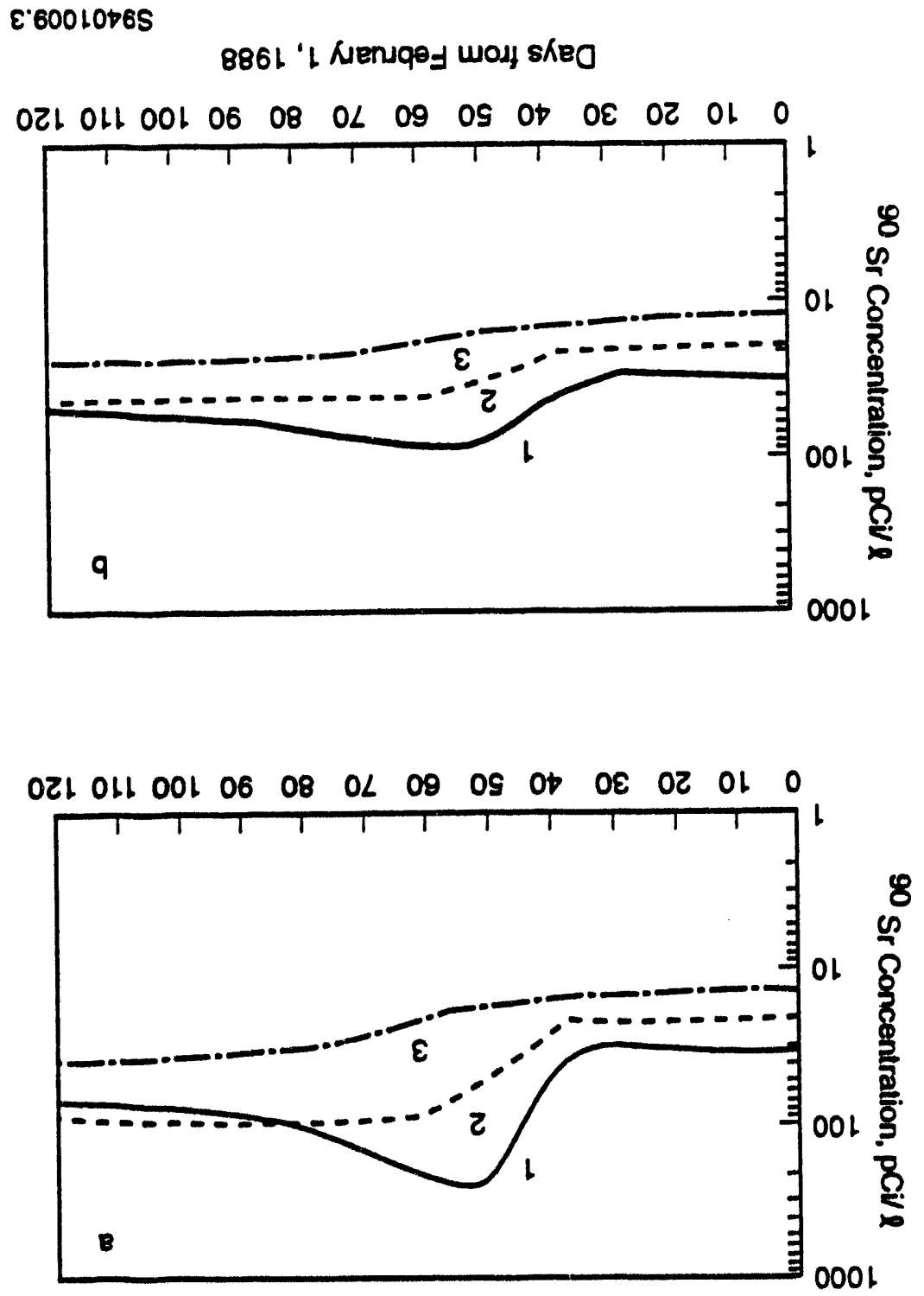


\subsection{Evaluation of the 1993 Summer Flood}

The 1993 summer flood on the Pripyat River, as described in Section 2.2, increased Pripyat River discharge to the Kiev Reservoir from $240-250 \mathrm{~m}^{3} / \mathrm{s}$ in the middle of July to $1100-1280 \mathrm{~m}^{3} / \mathrm{s}$ in the middle of August. Heavy rainfall over the Pripyat River watershed and the resulting sharp increase in Pripyat River inflow carrying radionuclides to the Kiev Reservoir caused concern about radioactive contamination of the Dnieper cascade among the population of Kiev and in the government. According to the authors' experience, the public in the Kiev region is psychologically more sensitive to the contamination of Dnieper River water by radionuclides than to any other environmental consequence of the Chernobyl accident.

Partially because of this public concern, the group of Ukrainian and U.S. scientists (the authors of this report), working together at PNL, received requests from both the Ukraine and the U.S. governments in July 1993 to evaluate the radioactive contamination of the Dnieper reservoirs under the impact of the Pripyat River flood while the flooding was progressing.

Taking into account the measured data on Pripyat/Dnieper contamination obtained during previous floods since the Chernobyl accident, special features of physical-chemical exchange processes (e.g., those among fiel particles, sediment, and water) in the zone near Chernobyl, and the results of previous modeling, it was assumed that only the ${ }^{90} \mathrm{Sr}$ concentration would change significantly under 1993 flood conditions. 
To rapidly perform an emergency evaluation of the migration and fate of ${ }^{90} \mathrm{Sr}$ in the Dnieper reservoirs, the WATOX box model described above and discussed in more detail in the Appendix was used. As described above, less than $10 \%$ of the ${ }^{90} \mathrm{Sr}$ is transported into the reservoirs by sediments, and the direct exchange of ${ }^{90} \mathrm{Sr}$ with the bottom deposition is occurring very slowly. Thus the conservative approach of not taking into account the adsorption of ${ }^{90} \mathrm{Sr}$ by bottom sediment gives reasonable results for describing short-term processes of ${ }^{90} \mathrm{Sr}$ transport in the reservoirs. Thus, simplified forms (without radionuclide-sediment interaction terms) of the equations in WATOX provide the mathematical basis for evaluating ${ }^{90} \mathrm{Sr}$ dynamics in the reservoirs. The numerical solution of these equations on the basis of scenarios of discharge from the Pripyat, Dnieper, and Desna rivers into the reservoirs has been used to predict radionuclide dynamics in the Dnieper River.

An initial evaluation based on the first available data on ${ }^{90} \mathrm{Sr}$ concentrations in the Pripyat River was made on August 10,1993. In a preliminary letter to the Ukrainian authorities through the Ukrainian Ministry of Chernobyl Affairs and to the United States Embassy in Kiev through Lawrence Livermore National Laboratory, we estimated that the maximum concentration of ${ }^{90} \mathrm{Sr}$ near Kiev (at the Kiev hydropower plant) would be approximately $15-17 \mathrm{pCi} / \mathrm{L}$, and the corresponding concentration in Kiev drinking water would not exceed 7-8 pCi/L.

After this initial evaluation, we then carried out validation and testing of existing mathematical models with supplementary data on reservoir cross sections (information on $\mathbf{5 0}$ cross sections of all Dnieper reservoirs was included for the modeling). Information on dam operations was also used in the water balance estimation for each reservoir. For predicting radionuclide transport, a typical dam operation was used for each reservoir. Ccmputer linkage to Ukrainian staff members in Kiev, who were responsible for monitoring the radionuclides in the water bodies, quickly brought to us necessary 
initial data on water and radionuclide influxes into the reservoir system from the upper Dnieper reservoirs. Some other data were used to calibrate and test model of the Dnieper River reservoir system.

The following are results for two scenarios. One scenario represented the actual summer 1993 flood case (Figure 20). The second represented one of the potential worst cases, with the maximum level of ${ }^{90} \mathrm{Sr}$ contamination in the Pripyat River, with maximum summer water discharge, and with a very low flow rate from the Dnieper River to the Kiev Reservoir (Figure 21). The results permit some conclusions concerning Dnieper River water contamination.

The reservoir that is most sensitive to radionuclide influx into the reservoir system is the Kiev Reservoir. The level of ${ }^{90} \mathrm{Sr}$ contamination in the upper part of the Kiev Reservoir due to radionuclide influx to the reservoir could increase by 1.5-1.7 times, and the maximum ${ }^{90} \mathrm{Sr}$ concentration in water near Kiev could rise to $13-16 \mathrm{pCi} / \mathrm{L}$. This maximum ${ }^{90} \mathrm{Sr}$ concentration then would be observed during the first 10 days of September. The expected maximum ${ }^{90} \mathrm{Sr}$ contamination for the middle part of the Kanev Reservoir would not exceed 10-12 pCi/L. The ${ }^{90} \mathrm{Sr}$ contamination in water in the middle part of the Krementchug Reservoir would reach $6 \mathrm{pCi} / \mathrm{L}$. The predicted total radionuclide flux from flooded watersheds to the Kiev Reservoir during two months of flooding were about $85 \mathrm{Ci}$ of ${ }^{90} \mathrm{Sr}$ from the Pripyat River and $16 \mathrm{Ci}$ from the Dnieper River.

The reasonably good matches between the predictions and the measured data for the Kiev Reservoir demonstrate the acceptability of the simple methodology used for this emergency response modeling (see Figure 20). However, the lack of current data from the Ukrainian radiation monitoring system made it impossible to compare all simulation results with measured data for downstream parts of the Dnieper reservoir system. Furthermore, the uncertainty (estimated to be about $30 \%$ ) of radionuclide 


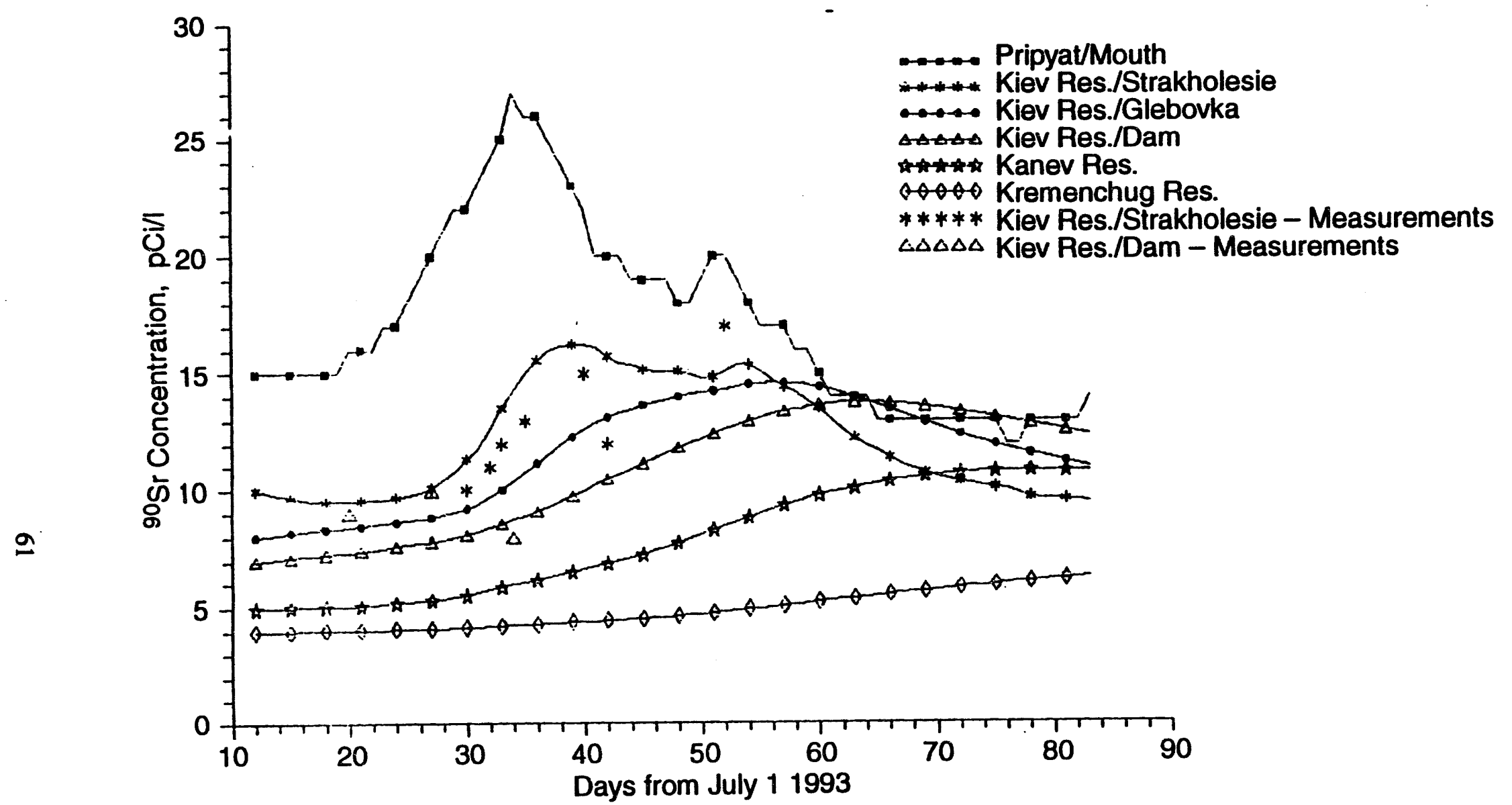

Figure 20. ${ }^{90} \mathrm{Sr}$ Concentration in the Pripyat River and the Dnieper Reservoirs During Summer 1993 Flood 


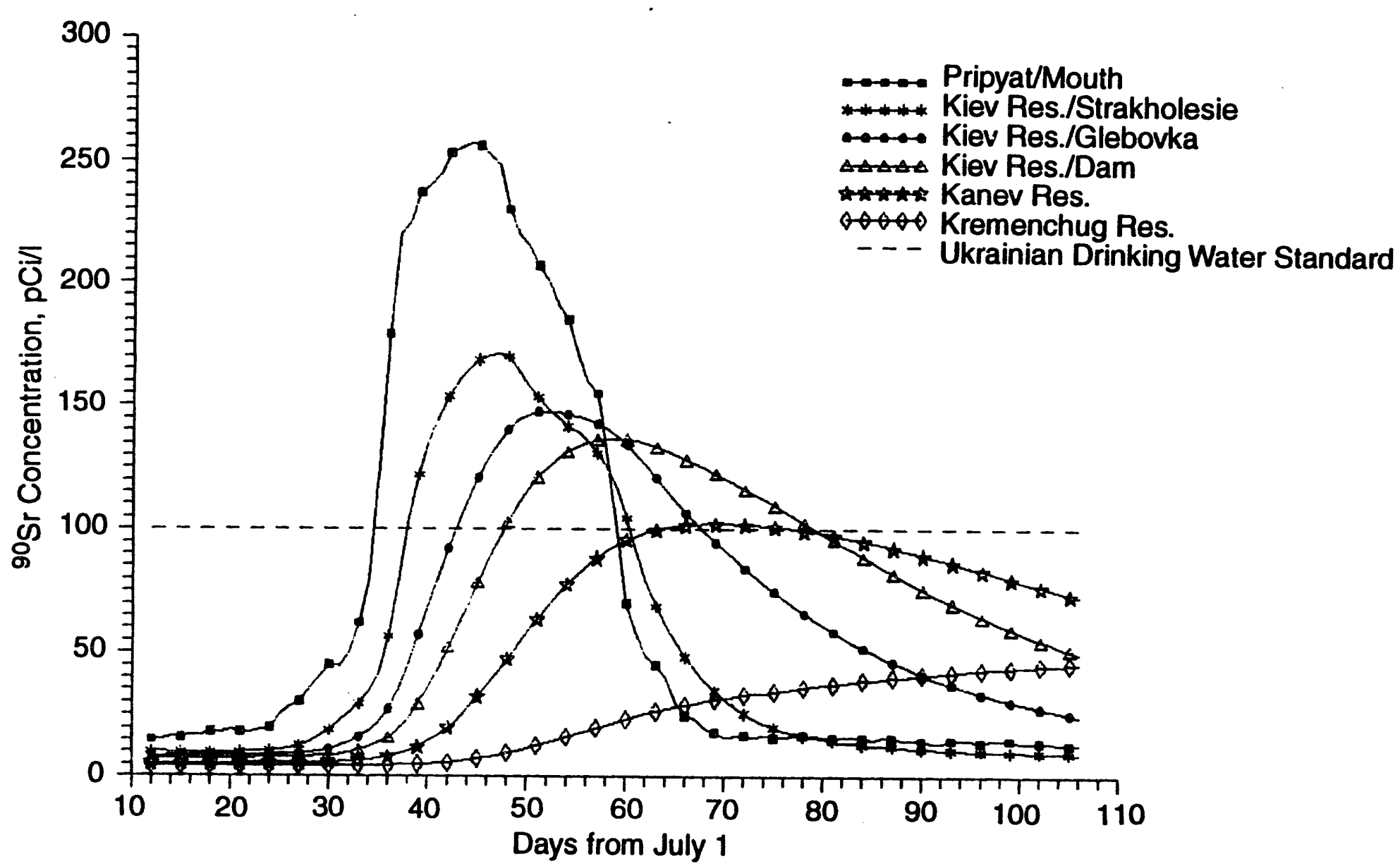

Figure 21. ${ }^{90} \mathrm{Sr}$ Concentration in the Pripyat River and the Dnieper Reservoirs for Scenario of the Pripyat Floodplain Flooding $\left(\mathrm{Q} \max =2000 \mathrm{~m}^{3} / \mathrm{s}\right)$ 
levels measured by the routine Ukrainian monitoring system will mask changes in the radionuclide concentrations in the downstream reservoirs of the Dnieper cascade. The summer 1993 radionuclide flux to the Dnieper reservoirs would not change the situation significantly.

The second scenario (see Figure 21) gave an opportunity to estimate what would happen in one of the worst conditions for the Dnieper reservoirs. Two main factors influence the worst cases of reservoir contamination: a large water discharge from the Pripyat River carrying the maximum possible level of contamination and very low water discharge in the Dnieper River. Such a combination could occur as a result of a localized rainstorm over the Pripyat River watersheds that does not affect the flow condition of the Dnieper River. Under these conditions, the Pripyat River's highly contaminated floodplain across from the Chernobyl Nuclear Power Plant can be flooded, producing one of the worst conditions for Pripyat River contamination. In this scenario, maximum Pripyat River discharge during the flood is about $2000 \mathrm{~m}^{3} / \mathrm{s}$ and the maximum possible ${ }^{90} \mathrm{Sr}$ concentration in the river is $150-250 \mathrm{pCi} / \mathrm{L}$ near the mouth of the Pripyat River (see Figure 21). As shown in Figure 21, in this case ${ }^{90} \mathrm{Sr}$ concentrations in almost all upper reservoirs of the Dnieper River cascade system would exceed the maximum permissible level for drinking water $(100 \mathrm{pCi} / \mathrm{L})$ for more than a month. This would be one of the worst situations for the Dnieper cascade and requires estimation of the potential radiation dose to the population of Ukraine. 


\subsection{Evaluation of Radiation Dose and Risk from Use of Dnieper River Waters}

One of the main concerns about consequences of the Chernobyl accident is the spread of radionuclides beyond the initially contaminated areas by radionuclides washing out overland and from the rivers. Expansion of the geographical scale of radionuclide contamination due to runoff and river flows spreading into the less contaminated downstream part of the Dnieper cascade requires more accurate evaluation of the supplementary risk to the population who live near the Dnieper cascade on the contaminated areas and consume both the radioactively contaminated Dnieper water and foods irrigated with water from the Dnieper reservoirs.

It is important to obtain a realistic understanding of actual risk to people living outside of the $30-\mathrm{km}$ zone to set adequate criteria for measuring the effectiveness of existing water-protection constructions in the $30-\mathrm{km}$ zone and to evaluate future countermeasures and water protective activity inside the 30-kai zone, using dose/risk assessment approaches and cost-benefit analysis methodology.

Recently, several studies evaluated dose estimation associated with drinking Dnieper River water or consumption of fish from the river (Repin and Berkovsky 1992; Prister et al. 1992; Karatchev and Tkatchenko 1993). However, the methodologies and assumptions used in these studies varied, and thus it is very difficult to compare the results. The main reason for uncertainties relative to the results are different input data, different data bases for individual and collective dose analyses, different complexity of models, and different experimental parameters and validation of model results. Some of 
the results of these previous studies and the available input data used for the studies are reviewed below. This study also reassessed collective dose to public through aquatic pathways.

\subsection{Characterization of Water Use on the Dnieper Reservoirs}

The main water uses contributing to individual and collective effective equivalent dose (EED) are drinking water, fisheries and fish consumption, and irrigation with water from the downstream part of the Dnieper cascade. According to official statistics, Dnieper River water is used in the municipal water system supplies for more than eight million people in 10 regions along the Dnieper's reservoirs and by the Crimea Republic (Table 11). The total population in this region is about 19 million.

The main consumers of drinking water from Dnieper's reservoir are the industrial regions of Dniepropetrovsk and Donatsk and the southern regions of Ukraine. Daily consumption of drinking water in these regions is usually accepted to be about 1.5 liters per day for one adult person.

The Dnieper reservoirs are also used intensively for commercial fishing. After the accident, there was no significant decrease in the fish catch in the reservoirs, even the Kiev Reservoir. Annual reports of statistical information by the Ukrainian State Department (Table 12) indicate that during 1986-1990 about 25000 tons of commercial fish were caught annually from all reservoirs on the cascade, including about 1200 tons per year from the most contaminated, the Kiev Reservoir. Fish consumption by professional fishers is expected to be about $70 \mathrm{~kg}$ per year. Annually averaged fish consumption for ordinary people in these regions (Table 11) is $17-21 \mathrm{~kg}$ per year. However, about $93 \%$ of the fish 
Table 11. Dnieper Water Usage for Municipal Drinking Water System

\begin{tabular}{|c|c|c|c|}
\hline Region & Water Source (reservoir) & $\begin{array}{l}\text { Quantity of } \\
\text { Water, } \\
1000 \mathrm{~m}^{3} / \text { day }\end{array}$ & $\begin{array}{l}\text { Population } \\
\text { Consuming } \\
\text { Water, in } 10^{3} \\
\text { People }\end{array}$ \\
\hline 1. Kiev & Kanev reserv. & 440 & 255 \\
\hline 2. Cherkassy & Kremenchug reserv & 80 & 226 \\
\hline 3. Kirovograd & Kremenchug reserv. & 157 & 371 \\
\hline 4. Poltava & Kremenchug reserv. & 108 & 257 \\
\hline 5. Dniepropetrovsk & $\begin{array}{l}\text { Zaporozhie reserv. } \\
\text { Kakhovlca reserv. } \\
\text { Dnieprodzerzinsk reserv. }\end{array}$ & 1134 & 1980 \\
\hline 6. Zaporozhie & Kakhovlca reserv. & 575 & 977 \\
\hline 7. Nikolaev & Kakhovlca reserv. & 160 & 367 \\
\hline 8. Kharkov & Dnieprodzerzinsk reserv. & 241 & 419 \\
\hline 9. Lugansk & Dnieprodzerzinsk reserv. & 60 & 96 \\
\hline 10. Donetsk & Dnieprodzerzinsk reserv. & 1121 & 2156 \\
\hline \multirow[t]{2}{*}{ 11. Crimea Republic } & Kakhovka reserv. & 231 & 494 \\
\hline & Total & 4307 & $7598^{(a)}$ \\
\hline \multicolumn{4}{|c|}{$\begin{array}{l}\text { (a) These data do not take into account the volume of water from the Desna River } \\
\text { consumed by Kiev citizens. This source provides drinking water for more than } \\
0.5 \text { million people in Kiev and the Kiev region. The levels of }{ }^{137} \mathrm{Cs} \text { contamina- } \\
\text { tion of Desna River near the water intake were close to the level of water con- } \\
\text { tamination near the city water intake from the Dnieper River, particularly during } \\
\text { the first years after the accident. Total consumers of contaminated drinking water } \\
\text { from the Dnieper River in the districts downstream of the Kiev Reservoir could } \\
\text { be about } 8 \text { million people. }\end{array}$} \\
\hline
\end{tabular}


Table 12. Fish Commercial Catch in Dnieper Reservoirs During 1983-1990, in Tons

\begin{tabular}{||l|r|r|r|r|r|r|r|r||}
\hline \multicolumn{1}{|c|}{ Reservoirs } & 1983 & 1984 & 1985 & 1986 & 1987 & 1988 & 1989 & 1990 \\
\hline Kiev & 1223 & 1485 & 1511 & 1271 & 1291 & 991 & 1261 & 1122 \\
\hline Kanev & 563 & 641 & 716 & 772 & 627 & 631 & 719 & 569 \\
\hline Krementchug & 6322 & 7010 & 9379 & 9686 & 9280 & 8754 & 10380 & 9199 \\
\hline Dnieprodzerzhins & 1015 & 931 & 989 & 1404 & 1088 & 1354 & 1323 & 1201 \\
\hline Zaporozhie & 644 & 679 & 733 & 863 & 740 & 822 & 887 & 808 \\
\hline Kakhovlca & 8013 & 8683 & 9028 & 9701 & 8515 & 9527 & 10018 & 9938 \\
\hline Lower Dnieper & 2745 & 2192 & 2402 & 2244 & 2728 & 2111 & 3855 & 3330 \\
\hline
\end{tabular}

consumed are caught from artificial and natural ponds outside the Dnieper Reservoir system.

Therefore, the contribution of Dnieper fish to people's fish diet in these regions is $1.3-1.5 \mathrm{~kg}$ per year.

Recreational fishing could add about $30 \%$ per year to this total. However, most of the fish are consumed locally by the fishers, collective farmers and their families, and by people who live along the reservoirs. For the largest reservoirs, Krementchug and Kakhovlca, the fish are distributed more widely to the adjacent regions. Thus previous collective dose estimations (Repin and Berkovsky 1992) have assumed that the population of fish consumers was the same as that of drinking water consumers, some eight million Ukrainians.

Perhaps the most important water use in the southern part of Ukraine is irrigation. More than 1.6 million hectares are irrigated with the Dnieper River water, 1.13 million hectares from the Kakhovlca Reservoir alone (see Table 13). Irrigation is mostly carried out using overhead sprinklers, ditches, and small canals. The most sensitive irrigated water usage according to Prister et al. (1992) is 
Table 13. Volumes of Dnieper's Water Consumption for Irrigation in Different Regions of Ukraine (Year 50\%-probability of exceeding of annual river's water discharges)

\begin{tabular}{||l|l|c|c||}
\hline \multicolumn{1}{|c|}{ Regions } & \multicolumn{1}{|c|}{$\begin{array}{c}\text { Water Source } \\
\text { (reservoirs or rivers) }\end{array}$} & $\begin{array}{c}\text { Volume } \\
\text { Irrigation Area } \\
(1000 \text { hectares) }\end{array}$ & $\begin{array}{c}\text { Consumption } \\
\left(\mathrm{km}^{3}\right)\end{array}$ \\
\hline 1. Chernigov & Dnieper, Desna reserv. & 16.0 & 0.030 \\
\hline 2. Kiev & Kanev reserv. & 117.6 & 0.187 \\
\hline 3. Cherkassy & Kremenchug reserv. & 48.3 & 0.077 \\
\hline 4. Poltava & Kremenchug reserv. & 43.9 & 0.088 \\
\hline 5. Kirovograd & Kremenchug reserv. & 47.0 & 0.127 \\
\hline 6. Dniepropetrovsk & Zaporozhie reserv. & 232.3 & 0.693 \\
\hline 7. Zaporozhie & Kakhovlca reserv. & 226.0 & 0.691 \\
\hline 8. Kherson & Kakhovlca reserv. & 412.9 & 1.429 \\
\hline 9. Nikolaev & Kakhovlca reserv. & 170.2 & 0.483 \\
\hline 10. Crimea Republic & Kakhovlca reserv. & 323.0 & 0.968 \\
\hline & Total & 1637.2 & 4.773 \\
\hline
\end{tabular}

flooding of rice crops (Table 14). Almost 50\% of the irrigated lands are used for fodder crops, which determine contamination of meat and milk; vegetables are planted in not more than $10 \%$ of total irrigated land (Table 15).

\subsection{Previous Estimation of Individual and Collective Long-Term Radiation Dose and Effects from Contamination of the Dnieper Aquatic Ecosystem}

Several studies have estimated dose from the water pathway. The sources for most data used in those studies are as follows: The data on the contamination of water bodies for the period after the accident were obtained by the Ukrainian Hydrometeorological Institute (Voitsekhovitch et al. 1991, 1993a,b). The data on fish contamination are from the Institute of Sanitary Hygiene of Ukraine and the 
Table 14. Specific Activity of Radionuclides in the Rice Crop, Bq/kg (Prister et al. 1992)

\begin{tabular}{|c|c|c|c|c|}
\hline \multirow[b]{2}{*}{ Year } & \multicolumn{2}{|c|}{${ }^{37} \mathrm{Cs}$} & \multicolumn{2}{|c|}{$S \mathbf{r}$} \\
\hline & Grain & Straw & Grain & Straw \\
\hline \multicolumn{5}{|c|}{ KHERSON REGION } \\
\hline \multicolumn{5}{|c|}{ Skadovsky District } \\
\hline 1972 & 0.24 & 0.56 & 0.03 & 0.41 \\
\hline 1982 & 0.07 & 0.16 & 0.03 & 0.30 \\
\hline 1985 & 0.06 & 0.10 & 0.01 & 0.12 \\
\hline 1986 & 0.10 & 0.18 & 0.01 & 0.11 \\
\hline 1987 & 0.16 & 0.29 & 0.02 & 0.15 \\
\hline 1988 & 0.15 & 0.22 & 0.02 & 0.21 \\
\hline \multicolumn{5}{|c|}{ Kalanchaksky District } \\
\hline 1987 & 0.16 & 0.30 & 0.03 & 0.27 \\
\hline 1988 & 0.16 & 0.26 & 0.03 & 0.23 \\
\hline \multicolumn{5}{|c|}{ CेRIMEA REGION } \\
\hline 1987 & 0.14 & 0.26 & 0.02 & 0.23 \\
\hline 1988 & $\overline{0.15}$ & 0.27 & 0.02 & 0.21 \\
\hline
\end{tabular}

Table 15. Specific Activity of ${ }^{137} \mathrm{Cs}$ in Products Obtained from the Irrigated Lands in $1988, \mathrm{~Bq} / \mathrm{kg}$ (Prister et al. 1992)

\begin{tabular}{|l|c|c|c|c|c|c|c||}
\hline \multicolumn{1}{|c|}{ Region, District } & Lucerne & W. Wheat & Tomato & Cabbage & Cucumber & Milk & Meat \\
\hline Cherkassy, Kanivsky & 0.34 & 0.11 & 0.01 & 0.002 & 0.01 & 0.22 & 1.11 \\
\hline Poltava, Kremenchutsky & 0.34 & 0.15 & 0.01 & 0.001 & 0.01 & 0.19 & 1.11 \\
\hline Dniepropetrovsk, Nizhnednieprovsky & 0.26 & 0.04 & 0.01 & 0.001 & 0.01 & 0.30 & 1.48 \\
\hline Kherson, Dnieprovsky & 0.17 & 0.11 & 0.01 & 0.001 & 0.01 & 0.30 & 0.74 \\
\hline Crimea, Sympheropolsky & 0.34 & 0.07 & 0.01 & 0.002 & 0.01 & 0.22 & 1.11 \\
\hline Reference districts without water use from Dnieper & & & & \\
\hline Kharkov, Lazovsky & 0.08 & 0.04 & 0.001 & 0.001 & 0.1 & 0.11 & - \\
\hline Donetsk, Krasnoarmeysky & 0.08 & 0.04 & 0.001 & 0.001 & 0.1 & 0.11 & 0.37 \\
\hline
\end{tabular}


Institute of Hydrobiology of the Ukrainian Academy of Sciences, and from original studies of fish contamination in the Kiev Reservoir by Ryabov (1990). Other studies of fish contamination related to dose assessment were carried out by Prister et al. (1992), Karatchev and Tkachenko (1993), and others. Preliminary dose estimates related to drinking Dnieper River water were provided during the initial period after the accident by various scientists (Izrael et al. 1990). Dose contribution from irrigated produce has been estimated by Prister et al. (1992) and others.

Unfortunately, none of these past studies analyzed integral dose and risk to the population health due to total water use and water consumption from the Dnieper cascade system. This study does not analyze all these issues. However, we have evaluated some methodological problems and sources of uncertainty to mitigate these problems for future Chernobyl studies.

With regard to the methodological approaches, it can be stated that the assessment of individual doses from known environmental concentrations is relatively straightforward. The dose is the product of concentration, consumption, and dose commitment factor. Dose estimation is more difficult when the environmental concentration is not known and must be estimated. This is generally the case for the Chernobyl dose/risk assessment case studies. In general, most radiation dose estimates were calculated by computer codes based on the recommendations and parameters established by International Commission on Radiological Protection (ICRP 1977, 1979, 1990). For example, Napier et al. (1988) used the GENII computer code.

The study whose objectives were closest to those of the present study was carried out by Repin and Berkovsky (1992). They evaluated importance of the water consumption as a dose contributing factor relative to other radiation-dose-contributing factors. They used simple models for individual and 
collective dose estimations, with the effective dose coefficients, given as expected dose factor normalized on the unit of consumed radioactivity, $0.36 \times 10^{-7} \mathrm{~Sv} / \mathrm{Bq}$ for ${ }^{90} \mathrm{Sr}, 0.2 \times 10^{-7} \mathrm{~Sv} / \mathrm{Bq}$ for ${ }^{134} \mathrm{Cs}$, and $0.14 \times 10^{-7} \mathrm{~Sv} / \mathrm{Bq}$ for ${ }^{137} \mathrm{Cs}$ (ICRP 1979). Repin and Berkovsky provided representative radiation dose estimates for the population living along the Dnieper cascade. Two kinds of exposure were assessed: exposure from external and internal uptakes of dose sources from the polluted terrestrial areas, and exposure from consumption of food products. Their study revealed that the largest contribution to dose for the Ukrainian population is through consuming bread and milk products. They also estimated total radiation dose exposure to the population living along the Dnieper River from sources that do not connect directly with drinking water use and other kinds of water consumption. Using these results, we estimated that the total radiation dose from exposure to ${ }^{90} \mathrm{Sr},{ }^{134} \mathrm{Cs}$, and ${ }^{137} \mathrm{Cs}$ expected up to year 2056, for an average human age of 70 years at that time, for the population of approximately eight million people living along the Dnieper River is about 25000 menSv. About 5000 menSv of the effective equivalent dose (EED) is to human organs already exposed to radiation during 1986-1992.

These estimates were used to assess the contributions of the water pathway to the total radiation dose and to the total health risk for the population directly or indirectly consuming water from the Dnieper cascade polluted by the Chernobyl accident. 


\subsection{The Role of Different Water Uses in the Effective Equivalent Dose (EED) Formation}

\subsubsection{Drinking water}

People living in the major cities along the Dnieper reservoirs generally use the public drinking water supply systems. Water treatment removes some portion of radionuclides, but the effectiveness of the public water treatment systems is not very high. The treatment factor for public water supply systems is no more than 3-4 times for ${ }^{137} \mathrm{Cs}, 1.2-1.5$ for ${ }^{90} \mathrm{Sr}$, and about 1 for ${ }^{131} \mathrm{I}$. In this study, as a conservative estimation, we did not assume public water treatment to be a significant water remedial factor. Adults are assumed to consume about 1.5 liters of potable water per day. Neglecting removal of radionuclides by the water treatment system, people consuming Dnieper River water have taken up corresponding radiation doses from ${ }^{137} \mathrm{Cs}$ and ${ }^{131} \mathrm{I}$ and are expected to receive an equivalent dose in future from ${ }^{90} \mathrm{Sr}$. Taking into account the problem of ${ }^{90} \mathrm{Sr}$ exposure of human organs, it is more accurate to estimate the expected radiation dose during the average human life (70 years) after the radionuclides were released to the environment.

The radiation dose of ${ }^{131} I$ for the initial period, a main contributor to exposure during May and June 1986, was estimated using recommendations of ICRP Publication No. 30 and are presented in Table 16. Following this, the estimated individual dose for Kiev citizens due to uptake of ${ }^{131} I$ through drinking water during first two months after the accident was about $2 \times 10^{-4} \mathrm{~Sv}$ per person. According to the estimation for the lower part of the Kiev Reservoir in 1986, individual dose contribution from 
Table 16. Estimation of ${ }^{137} \mathrm{Cs}$ Concentration in Different Fish Species Caught from the Kiev Reservoir, in Bq/kg (fresh mussels weight)

\begin{tabular}{|c|c|c|c|c|c|}
\hline $\begin{array}{l}\text { Fish } \\
\text { Species }\end{array}$ & 1987 & 1988 & 1989 & 1990 & 1991 \\
\hline Perch & $1.5-3.0$ & $1.5-3.4$ & $1.2-3.4$ & $0.7-1.7$ & $0.6-1.3$ \\
\hline Pike & $0.8-2.8$ & $0.9-1.6$ & $0.8-1.5$ & $0.6-1.3$ & $0.5-1.1$ \\
\hline Tench & $0.7-1.7$ & $0.6-0.9$ & $0.5-0.8$ & $0.2-0.8$ & $0.3-0.5$ \\
\hline Bream & $0.5-1.0$ & $0.4-0.9$ & $0.3-0.7$ & $0.2-0.5$ & $0.1-0.3$ \\
\hline Rudd & $0.4-1.1$ & $0.3-0.7$ & $0.2-0.5$ & $0.1-0.4$ & $0.1-0.3$ \\
\hline \multicolumn{6}{|c|}{$\begin{array}{l}\text { (a) Averaged data from different available sources originally obtained by } \\
\text { I. Ryabov (Ecopolis), N. Tkachenko (Ukrainian Hygiene Center), and } \\
\text { O. Nasvit (Institute of Hydrobiology). }\end{array}$} \\
\hline
\end{tabular}

${ }^{90} \mathrm{Sr},{ }^{89} \mathrm{Sr},{ }^{134} \mathrm{Cs}$, and ${ }^{137} \mathrm{Cs}$ in drinking treated water was about $8.7 \times 10^{-5} \mathrm{~Sv}$ per year. ${ }^{(a)}$ Thus $70 \%$ of the radiation dose to the Kiev population during 1986 was due to ${ }^{131} \mathrm{I}$ in the drinking water. Monthly averaged data on water contamination of all Dnieper reservoirs by were used by Repin and Berkovsky (1992) to estimate the incremental individual and collective EED for internal exposure to ${ }^{90} \mathrm{Sr}$ and ${ }^{137} \mathrm{Cs}$ by eight million people living along the Dnieper reservoirs that was due to consumption of drinking water during 1986-1982.

The current study estimates that the total collective EED for people living in the 11 regions of Ukraine along the Dnieper River were approximately 216 menSv for 1986-1992 and will reach up to about 900 menSv by the year 2056 . These estimates are preliminary because of the uncertainty of

(a) Personal communications to B. A. Napier and W. L. Templeton at PNL. 
available data on consumption of drinking water from the Dnieper River. The range and magnitude of the uncertainty introduced by different researchers due to different sets of input information is likely to be significant.

The main differences among previous studies reflect the large uncertainty related to contamination of different fish species. Concentrations of ${ }^{137} \mathrm{Cs}$ in different kinds of fish obtained by the Institute of Sanitary Hygiene and the Institute of Hydrobiology are presente $\_$in Table 16.

Using some preliminary parameters of radiation dose exposure from fish consumption obtained by Repin and Berkovsky (1992) and Karatchev and Tkatchenko (1993), the contribution from the fish pathway was evaluated here (Tables 16 and 17). The collective EED doses to all potential fish consumers (19 million people) would be about 80 menSv, resulting from exposures during 1986-1992 to ordinary consumers of fish. An additional 20 menSv could be contributed, if recreational fishermen in the same population (about 30\%) are also taken into account. For people who also consume drinking water (about 8 million people), presumably taking into account that people living along the Dnieper River consume not less than $70 \%$ of the calght fish in their diet) received 70 menSv. Accurate evaluation and assessment of these results is very difficult. However, assessing different groups of consumers of water-related products (professional fishers, recreational fishers, or ordinary fish consumers) for individual or collective radiation dose exposure could produce significantly different results. 
Table 17. Increment of Collective Effected Equivalent Dose of Internal Exposure to Population Living Along the Dnieper Reservoirs and Expected Risks Due to Different Water Usage and Water Intake During 1986-1992(a)

\begin{tabular}{|c|c|c|c|c|c|c|}
\hline \multirow[b]{2}{*}{ Types of Water Usage } & \multirow{2}{*}{$\begin{array}{l}\text { No. of } \\
\text { Exposed } \\
\text { People } \\
\text { (million) }\end{array}$} & \multirow{2}{*}{$\begin{array}{c}\text { Annual } \\
\text { Consumption } \\
\text { of Products } \\
\text { (kg/year) }\end{array}$} & \multicolumn{2}{|c|}{$1986-1992$} & \multirow{2}{*}{$\begin{array}{c}\text { Equivalent } \\
\text { Radiation } \\
\text { Risks }\end{array}$} & \multirow{2}{*}{$\begin{array}{l}\text { Contribution } \\
\text { of the } \\
\text { Pathways } \\
(\%)\end{array}$} \\
\hline & & & $\begin{array}{c}\text { EED } \\
\text { (MenSv) }\end{array}$ & $\begin{array}{l}\text { Cancer } \\
\text { Effect }\end{array}$ & & \\
\hline Drinking water consumption & 8 & 1.5 & 216 & 16 & $2.0 \times 10^{-6}$ & $\begin{array}{l}4.4 \\
1.9\end{array}$ \\
\hline $\begin{array}{l}\text { Fish products consumption } \\
\text { by all people living in the } 11 \\
\text { regions and drinking water } \\
\text { from Dnieper res. }\end{array}$ & $\begin{array}{r}19 \\
8\end{array}$ & $\begin{array}{l}1.4 \\
2.0\end{array}$ & $\begin{array}{c}100 \\
70\end{array}$ & $\begin{array}{l}7 \\
5\end{array}$ & $\begin{array}{l}3.7 \times 10^{-7} \\
6.8 \times 10^{-7}\end{array}$ & $\begin{array}{l}1.4 \\
0.8\end{array}$ \\
\hline $\begin{array}{l}\text { Consumption of food } \\
\text { products from irrigated areas } \\
\text { by people who also drink } \\
\text { water from Dnieper and } \\
\text { consume fish }\end{array}$ & $\begin{array}{r}19 \\
8\end{array}$ & & $\begin{array}{l}513 \\
216\end{array}$ & $\begin{array}{l}38 \\
16\end{array}$ & $\begin{array}{l}2.0 \times 10^{-6} \\
2.0 \times 10^{-6}\end{array}$ & $\begin{array}{l}4.4 \\
4.4\end{array}$ \\
\hline $\begin{array}{l}\text { Total collective EED from } \\
\text { sources that are linked with } \\
\text { water usage }\end{array}$ & $\begin{array}{r}19 \\
8\end{array}$ & & $\begin{array}{l}829 \\
502\end{array}$ & & $\mid \begin{array}{l}3.2 \times 10^{-6} \\
4.6 \times 10^{-6}\end{array}$ & $\begin{array}{r}7.0 \\
10.2\end{array}$ \\
\hline $\begin{array}{l}\text { Total collective EED from } \\
\text { sources which include those } \\
\text { not linked with water usage }\end{array}$ & $\begin{array}{r}19 \\
8\end{array}$ & & $\begin{array}{r}11832 \\
4982\end{array}$ & $\begin{array}{l}864 \\
364\end{array}$ & $\begin{array}{l}4.5 \times 10^{-5} \\
4.5 \times 10^{-5}\end{array}$ & $\begin{array}{l}100 \\
100\end{array}$ \\
\hline $\begin{array}{l}\text { (a) Results reflect the EED } \\
\text { Tkashenko (1993). } \\
\text { (b) Two population groups } \\
\text { drink water from the res } \\
\text { products that are caught }\end{array}$ & $\begin{array}{l}\text { jenc } \\
\text { jir's }\end{array}$ & enin anc & $\begin{array}{l}\text { eopl } \\
\text { 2) } 1\end{array}$ & 92) & Karatch & $\begin{array}{l}\text { ad and } \\
\text { me fish }\end{array}$ \\
\hline
\end{tabular}

Comparing individual radiation dose estimates from Karatchev and Tkachenko (1993) indicates that the main contributors to radiation dose for professional fishers would be the fish pathway. However, the analysis on collective dose estimates for ordinary consumers of fish from the Dnieper reservoirs indicates that the main factors in dose exposure will be drinking water and perhaps the irrigation pathway. 
The main difficulty for decision-makers using these results is estimating the adequacy of the data on the basis of uncertainty analysis. Another problem is to transfer individual dose estimates on to the larger population groups.

\subsubsection{Irrigation Water Use}

Another important source of radionuclide intake to the human organism is agricultural products produced on the irrigated lands in the Dnieper River watershed. Prister et al. (199:) show that the contamination of Dnieper River water by ${ }^{137} \mathrm{Cs}$ resulted in a perceptible increase of its concentration in crops in comparison with those obtained in the Kharkov and Donetsk regions, where sources of irrigation water were not connected with the Dnieper drainage basin (see Table 15). The ${ }^{137} \mathrm{Cs}$ concentrations in crops are 2-4 times greater for those that are watered 3-6 times during the vegetation period and which, due to their physiological features, receive radionuclides by the nonroot (aerial) pathway; in contrast, for cucumber and cabbage, which are covered with a cuticular nonwettable layer, ${ }^{137} \mathrm{Cs}$ contamination is similar for the two regions being compared (Table 15). Differences in the ${ }^{137} \mathrm{Cs}$ content in forage cause differences in radionuclide levels in cow's milk and meat. In the uncontaminated control regions, radionuclide concentrations in cow's milk and meat are 1.5-2.5 times less than those in milk and meat where Dnieper River water is used for irrigation.

Using soil contamination data in the Dnieper River drainage basin and experimental data on radionuclide transfer factors from soil to agricultural plant via the root pathway, Prister et al. (1990) have shown that, for the irrigation case, radionuclide uptake in the crops is mainly determined by aerial 
contamination. However, contamination of rice is of special interest because rice grows in flooded lands. Several research teams carried out observations in 15 farms of Crimea during harvest to obtain the information used.

An accurate estimation of the contribution of irrigation pathways to radiation dose exposure has not been achieved yet. Many uncertainty factors control the processes relating to contamination of irrigated plants. We hope to perform a more accurate assessment during the next stage of our study. Meanwhile, some recently obtained study results indicate that for an individual who lives in the middle or upper districts of Ukraine along the Dnieper River, most of the radiation dose due to aquatic factors comes from consumption of drinking water and fish. For southern regions where there is more consumption of irrigated agricultural products, the significance of water use for irrigation and the radiation exposure for population corresponding to this pathway increases especially when the calculated individual radiation dose is used to estimate the dose to all consumers of irrigated food products (mostly in the same eleven regions, with their population of about 19 million people). So, for collective dose estimates, irrigation as a dose-contributing factor for the water pathway increases significintly. This is the main difference between using the individual or the collective radiation dose estimates to assess the contribution of the irrigation pathway to radiation risk for large contaminated areas where water use is complex.

Thus, it is very important to compare the effects of the different contributors to the total radiation dose and to the appropriate risk for people's health for different population groups. 


\subsection{Description of Some Approaches for Radiation Risk Estimation from Dnieper Water Use}

The main purposes of the radiation risk assessment were to provide key information to decisionmakers and to determine the effects of a variety of policy actions. Radiation risk estimates are usually based on the correlation between radiation dose exposure for population and a statistically defined cancer effect for population. This study did not intend to develop a new methodology for risk estimation based on water use. However, analysis of some previous data shows that the uncertainty of radiation dose (risk) estimations is connected with the range of partial dose (risk) contributors. It must be assumed that dose estimates in previous studies are correct. In this case, based on the recommendations of ICRP Publication No. 60 (ICRP 1990), the simplest way to adequately estimate the radiation risk is to use the recommended value of the specific radiation risk coefficient $\left(7.3 \times 10^{-2}\right)$ multiplied by the values of the radiation dose estimates from each dose contributor. So the first stage of estimating risk from water use for people living along the Dnieper River is to assess the radiation dose components from each water pathway (drinking water, fishing, irrigation). The ratio between different radiation risk components from different types of water use would be similar to the ratio between appropriate dose estimates $f \mathrm{r}$ the same types of water use.

For the southern Ukrainian regions, radiation doses from drinking water come mainly from ${ }^{90} \mathrm{Sr}$ (10 times more than from ${ }^{137} \mathrm{Cs}$ ). Radionuclide uptake through consumption of fish caught in the Dnieper reservoirs contributed most to dose in 1987-1989, but its contribution is now decreased by 2-5 times. However, for the same period, relative contribution of radiation dose through drinking water rose by an order of magnitude. Even more changes, two orders of magnitude and more, on 
relative contributions of different water pathways take place for fishermen. The EED to fishermen from only ${ }^{137} \mathrm{Cs}$ in fish reached 2 menSv/year during 1987-1989.

The contribution of the Dnieper cascade to the collective EED in Ukraine was estimated here on the basis of previous work by Repin and Berkovsk, (1992) and Karatchev and Tkachenko (1993), using the actual radiation situation and water use on the Dnieper reservoirs in 1989. The EED from drinking water was calculated as about 40 menSv, the EED from fish consumption was about 13 menSv; the EED from irrigation (including crops, milk, and meat from irrigated areas) was very conservatively estimated as about 100 menSv for 1989. However, Repin and Berkovsky (1992), taking into account the large uncertainty related to the irrigation pathway contribution, have assumed that the internal radiation dose contribution from consumption of irrigated products could be as much as that of the drinking water pathway.

Analyzing the results presented in Table 17 , and a value of $0.073 \mathrm{~Sv}^{-1}$ for the specific radiation risk factor (ICRP 1990), the total expected human cancer effect due to the use of Dnieper River water in 1986-1992 will be 61 people with cancers in the total population of about 19 million. This value could increase if hydrological (and radiologica!) conditions on the Dnieper reservoirs change. If we take into account the size of the affected population (about 19 million), we estimate the individual risk from total water usage to be no more than about 3-5 $\times 10^{-6}$. For the same population of Ukraine (19 million), total radiation risk from all pathways is estimated to be in the range $4.5 \times 10^{-5}$.

Thus, it could be concluded from this study that radioactive contamination of the Dnieper aquatic system and the resulting radiation pathways is not a dominant factor for radiation risk compared with other radiation risk contributors. The contributions to risk from consumption of drinking water, fish, 
and irrigated food proc acts could compose only 5-10\% of the total radiation risk resulting from the Chernobyl accident, which exposed the same people during 1986-1992. However, providing a waterprotective countermeasure inside the Chernobyl close-in zone would remaln important for several reasons:

1. There were no higher floods on the Pripyat River during most of the years after the accident (maximum water discharge during 1986-1992 was about $1200 \mathrm{~m}^{3} / \mathrm{s}$; the discharge of higher floods would be $4000-5000 \mathrm{~m}^{3} / \mathrm{s}$ and more).

2. Most $(90 \%)$ of the internal individual radiation dose for the Ukrainian population due to drinking water consumption was contributed by ${ }^{131} \mathrm{I}$ during the first months after the accident in 1986. However, most water-protective activities were implemented much later. Clearly it is very important to develop an emergency response and forecast methodology to evaluate the consequences of potential similar accidental cases on the large rivers to develop effective countermeasures.

3. It is necessary to recalculate more accurately all dominant contributions by the water pathway to the radiation dose exposure. It is also very important to understand how to estimate the effectiveness of the countermeasure activities carried out during 1986-1993.

The Pripyat/Dnieper River aquatic system is the only link among all the population (about 19 million) who consume the Dnieper water and have been exposed to radionuclides as dispersion and migration processes take place inside the $30-\mathrm{km}$ zone around Chernobyl. A number of questions remain to be answered: How can the recent findings of radionuclide migration studies and a long-term estimation of radionuclides dispersion in surface water and in groundwater be applied to modernize monitoring of water bodies? How can retention factors be estimated for the Chernobyl area's landscape and how can self-purification of water bor'ies, as a water-remedial environmental factor, be estimated for comparisons with the expected effectiveness of water-protective activities? How can the most adequate technologies for remediation or clean-up activities be identified? How can general health risk from water use be estimated by taking into account the fact that existing chemical contamination of the Dnieper 
River system and synergistic effects might create a risk that significantly exceeds the radiation effect.

All these issues must be evaluated using risk-benefit analysis methodology, as one of the main tasks of the next stage of the Ukraine/USA joint Chernobyl case study. 


\subsection{Summary and Conclusions}

This report describes the joint activities of Program 7.1.F, "Radionuclide Transport in Water and Soil Systems," of the USA/CIS Joint Coordinating Committee on Civilian Nuclear Reactor Safety to study hydrogeochemical behavior of radionuclides released from the Chernobyl Nuclear Power Plant in Ukraine. The study evaluated radionuclide distributions in the Pripyat-Dnieper river system and their potential human impacts based on field data and modeling. The joint activities also included rapid evaluation of the radionuclide distribution in this river system during the 1993 summer flood to assist the Ukrainian government in their emergency response, during the flood.

Approximately 50 million curies (or 4\%) of the fission products and activates in Reactor Unit No. 4 were released to the atmosphere during the 11 days following April 26, 1986, including 1.3 and 0.24 million curies of ${ }^{137} \mathrm{Cs}$ and ${ }^{90} \mathrm{Sr}$, respectively. A significant portion of these radionuclides were deposited on the watersheds of the Pripyat and Dnieper rivers in Ukraine, Belarus and southwestern Russia. Consequently, there has been long-term influx of ${ }^{137} \mathrm{Cs}$ and ${ }^{90} \mathrm{Sr}$ into these rivers, which pass through six reservoirs before discharging into the Black Sea, about $1000 \mathrm{~km}$ downstream. Radionuclide composition of the fallout over these areas was heterogeneous, varying with direction and distance from the Chernobyl Nuclear Power Plant. Much of the ${ }^{90} \mathrm{Sr}$ was deposited within a 30-km zone around the plant; it was originally associated with hot fuel particles that gradually change forms to become more soluble and exchangeable through inechanical destruction and dissolution of the fuel component. On the other hand, ${ }^{137} \mathrm{Cs}$ was deposited in three distinct areas, and its association with hot fuel particles was limited to those deposited near the Chernobyl Nuclear Power Plant. Field data collected within the 30-km zone indicate that although ${ }^{137} \mathrm{Cs}$ and ${ }^{90} \mathrm{Sr}$ leached into the soil at approximately the same rate, 
the effective washout of ${ }^{137} \mathrm{Cs}$ from the local watershed decreased with time, because the amount of ${ }^{137} \mathrm{Cs}$ in the exchangeable form decreased as a result of fixation with soil. In contrast, the effective washout of ${ }^{90} \mathrm{Sr}$ has stayed at about the same level for seven years since the accident.

Radionuclide levels in the Pripyat and Dnieper rivers rose almost immediately after the accident, then decreased significantly. Total beta activity in the Pripyat River water was above $0.1 \mu \mathrm{Ci} / \mathrm{L}$ in the first day after the accident, but had decreased to $4.6 \mathrm{nCi} / \mathrm{L}$ by the end of May 1986 . The highest measured ${ }^{90} \mathrm{Sr}$ level in the Pripyat River was $400 \mathrm{pCi} / \mathrm{L}$ in the first few days of May 1986, and levels decreased to $30-50 \mathrm{pCi} / \mathrm{L}$ within the next two months. Plutonium concentrations in the river reached $10 \mathrm{pCi} / \mathrm{L}$ in the first days after the accident but dropped to $0.2 \mathrm{pCi} / \mathrm{L}$ by August 1986 . Up to $98 \%$ of the plutonium was associated with suspended and bottom sediment. Cesium-137 shows a clear affinity to fine sediment, and the percentage of suspended sediment-sorbed ${ }^{137} \mathrm{Cs}$ varied from 20 to $80 \%$. The highest ${ }^{131}$ I content measured at the Dnieper River drinking water intake for the City of Kiev was $300 \mathrm{pCi} / \mathrm{L}$ on May 3, 1986.

In recent years, ${ }^{137} \mathrm{Cs}$ and ${ }^{90} \mathrm{Sr}$ concentrations in the Pripyat and Dnieper rivers have become lower. During 1992, the average ${ }^{90} \mathrm{Sr}$ concentrations were $20-30 \mathrm{pCi} / \mathrm{L}$. near the mouth of the Pripyat River and 1-5 $\mathrm{pCi} / \mathrm{L}$ in the lower reservoirs of the Dnieper River. Concentrations of ${ }^{137} \mathrm{Cs}$ were somewhat lower than those of ${ }^{90} \mathrm{Sr}$, averaging $0.1-1 \mathrm{pCi} / \mathrm{L}$ in the Dnieper reservoirs for 1991-1993. This level is close to the background level caused by global radionuclide fallout.

Despite the general pattern of falling concentration, flooding of the Pripyat River has proved to be a serious radiation problem. The Pripyat River floodplain (approximately $2 \mathrm{~km}$ wide and $10 \mathrm{~km}$ long) directly across from the Chernobyl Nuclear Power Plant received a significant amount of ${ }^{137} \mathrm{Cs}$ and ${ }^{90} \mathrm{Sr}$ 
deposition after the accident with ${ }^{90} \mathrm{Sr}$ concentrations of up to $1000 \mu \mathrm{Ci} / \mathrm{m}^{2}$, accounting for approximately half of all ${ }^{90} \mathrm{Sr}$ entering the Pripyat River. During 1991 winter flooding of the Pripyat River caused by an ice jam, the peak ${ }^{90} \mathrm{Sr}$ concentration at Yanov Bridge (at the downstream end of the floodplain) was above $250 \mathrm{pCi} / \mathrm{L}$, exceeding the current Ukrainian drinking water standard of $100 \mathrm{pCi} / \mathrm{L}$ for ${ }^{90} \mathrm{Sr}$. Thus, the assessment and control of the radionculide migration during flooding are critically important from the viewpoint of public health.

Despite remediation measures, the problem of increasing of ${ }^{90} \mathrm{Sr}$ concentrations in the Pripyat and Dnieper rivers during high floods still remains. In July-August 1993, heavy rainfall over the Pripyat River catchment in Belarus and Ukraine caused severe floouing, significantly raising ${ }^{90} \mathrm{Sr}$ concentrations in the river. Because of heightened public concern about radionuclide levels in the river and the need of the Ukrainian government to make an emergency response, we conducted an emergency evaluation of radionuclide distributions in the Dnieper River while the flooding was occurring. Near the Chernobyl area, the maximum ${ }^{90} \mathrm{Sr}$ concentration in the Pripyat River rose to about 20-25 pCi/L in early August; near the Pripyat River mouth, the concentration reached $35 \mathrm{pCi} / \mathrm{L}$. The peak ${ }^{90} \mathrm{Sr}$ concentration in the Kiev Reservoir (a major source of drinking water for Kiev) was $12 \mathrm{pCi} / \mathrm{L}$. However, by the end of August 1993 , the ${ }^{90} \mathrm{Sr}$ concentration at the mouth of the Dnieper River at the Black Sea was still only $6-8 \mathrm{pCi} / \mathrm{L}$. If the $10-\mathrm{km}$ dike had not been constructed, ${ }^{90} \mathrm{Sr}$ concentrations in the Pripyat River, and thus also in the Dnieper River, would have been much higher.

Unlike ${ }^{90} \mathrm{Sr},{ }^{137} \mathrm{Cs}$ concentrations in the Pripyat River during the flood did not rise significantly from the pre-flood levels. Concentrations of ${ }^{137} \mathrm{Cs}$ in river water around the Chernobyl site reached only 5-7 $\mathrm{pCi} / \mathrm{L}$. In the middle of July, ${ }^{137} \mathrm{Cs}$ concentrations in the Kiev Reservoir and further downstream in the Kanev Reservoir were $2-5 \mathrm{pCi} / \mathrm{L}$ and $1-3 \mathrm{pCi} / \mathrm{L}$, respectively. 

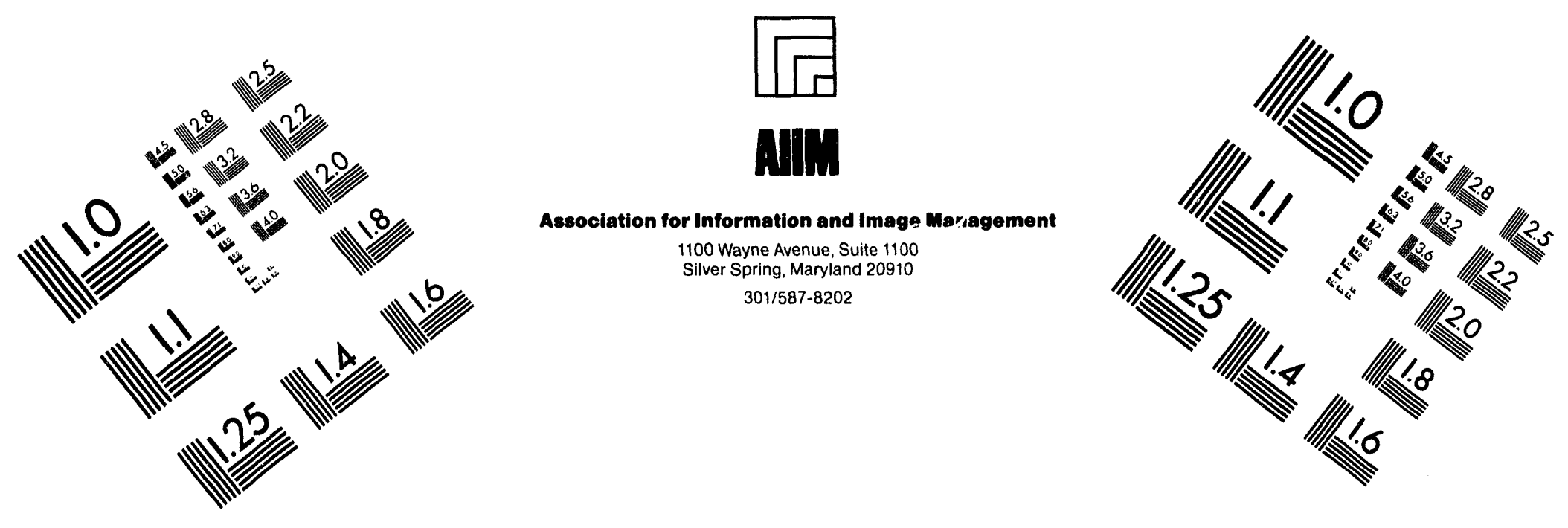

\section{Centimeter}

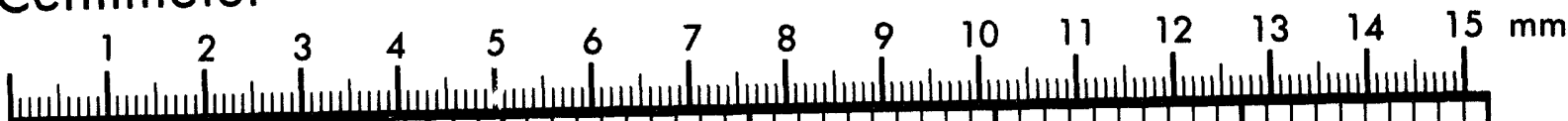

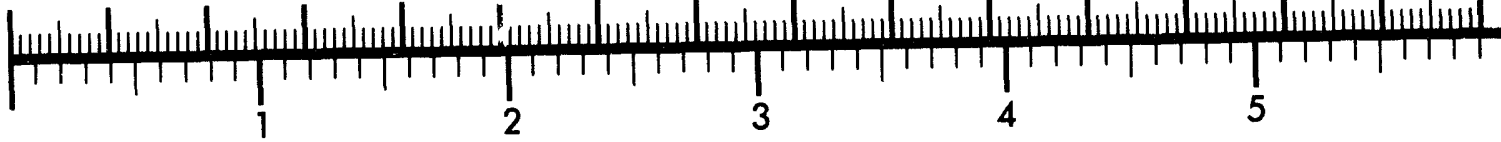
Inches

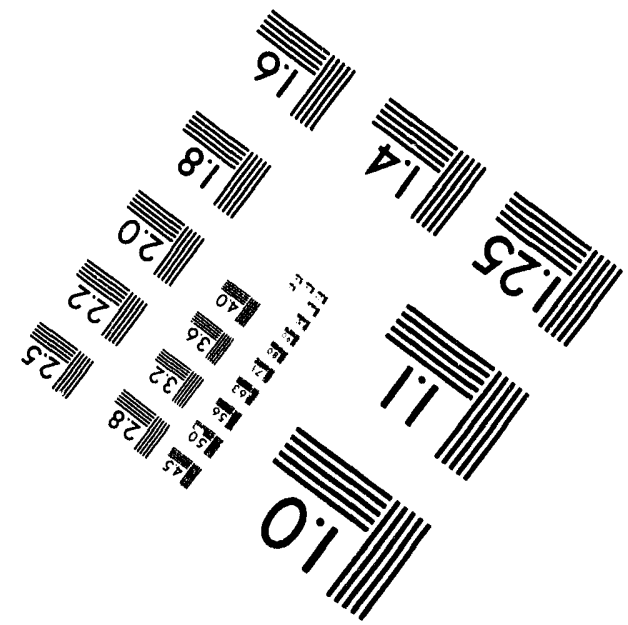

MANUFACTURED TO AIIM STANDARDS

$$
\text { BY APPLIED IMAGE, INC. }
$$

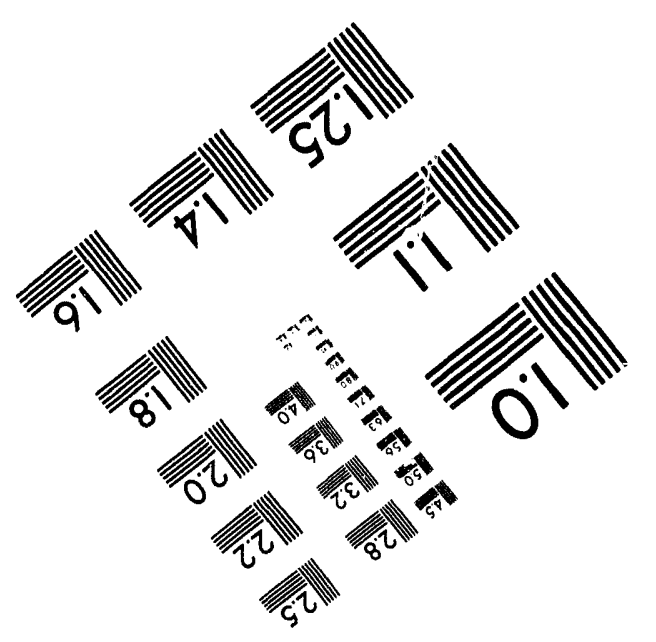




$$
\stackrel{N}{\stackrel{N}{N}}
$$


Based on the measured radionuclide levels, additional modeling results, and the assumption of water purification in a water treatment station, ${ }^{90} \mathrm{Sr}$ concentrations in the city of Kiev's drinking water were estimated to be less than $8 \mathrm{pCi} / \mathrm{L}$. Estimated ${ }^{137} \mathrm{Cs}$ concentrations for Kiev's drinking water were two orders of magnitude lower than the drinking water standard of $500 \mathrm{pCi} / \mathrm{L}$ for ${ }^{137} \mathrm{Cs}$. Thus the water was determined to be safe for Kiev citizens to drink during the 1993 summer flood.

About 19 million people in Ukraine consume water from the Dnieper River between Kiev and the Black Sea and thus are exposed to the impacts of the radionuclides in the river through drinking water, irrigation, and fishing; 8 million consume the Dnieper River water as their drinking water. With the most current water use information available to us, we calculated collective effective equivalent dose (EED) of internal exposure to the population and expected risks due to differential water usage. It was estimated that during 1986-1992, the collective EED for the 19 million people that resulted from 8 million people drinking the Dnieper River water, and 19 million people consuming fish or irrigated food products were 216,100 , and 513 menSv, respectively, totalling 829 menSv. The irrigation pathway is clearly the dominant pathway among the aquatic pathways for these 19 million people. The total aquatic pathway contribution constitutes about $7.0 \%$ of the total collective EED of 11,832 menSv resulting from all pathways. If only the 8 million people who not only drink river water but also consume fish and irrigated food products are considered, their collective EEDs for drinking water and consuming fish and irrigated food products are 216,70 , and 216 menSv, respectively, totalling 502 menSv. For this population, the total EED from all pathway sources is 4,982 menSv; thus the water pathway contribution to collective EED constitutes $10 \%$ of the total pathway contributions. (The collective EED from all pathways for these 8 million people over the period 1986-2056, corresponding to an average human lifetime of 70 years, is estimated to be approximately 25,000 menSv). The equivalent radiation risks from the aquatic pathway for the 19 million and 8 million people are $3.2 \times 10^{-6}$ 
and $4.6 \times 10^{-6}$, respectively, as compared to $4.5 \times 10^{-5}$ from the total pathways. The expected human cancer effects resulting from drinking Dnieper River water and consuming radioactively contaminated fish and irrigated food products are estimated to be 16,7 , and 38 people with cancers, totalling 61 people in the total population of 19 million. Of the 8 million who drank the water, there will be 16 , 5, and 16 people with cancer, totalling 37 people with cancers. The total number of people who will get cancers due to all pathways are expected to be 864 and 364 among the 19 million Ukrainians and 8 million who drink the Dnieper River water.

Field data evaluation and modeling revealed that flooding is a critical factor that increases radionuclide concentrations in the rivers. The construction of the $10-\mathrm{km}$ dike in the floodplain across from the Chernobyl Nuclear Power Plant proved to be effective for reducing ${ }^{90} \mathrm{Sr}$ concentrations in the Pripyat River. However, despite construction of the dike, radionuclide migration and interaction between the floodplain and the Pripyat River remains a major long-term problem. This surface and groundwater interaction must be assessed in the future.

Even though the aquatic pathway contributes only 7 to $10 \%$ of the total dose from all the pathways, radionuclide migration into and within the rivers is important for determining potential dose to people. This is the case mainly because most of the practical current and future remediation will be within the $30-\mathrm{km}$ protection zone to control and reduce potential radionuclide migration in the aquatic pathways. It is important to obtain a realistic understanding of actual risks from the aquatic pathway to people living outside the $30-\mathrm{km}$ zone to develop adequate criteria for measuring the effectiveness of current and future remediation and water protection activities inside the $30-\mathrm{km}$ zone, based on dose/risk assessment and cost-benefit analysis. 


\subsection{References}

Bobovnikova, C. I., E. P. Virtchenko, and A. V. Konoplev. 1990. "Chemical Forms of Long-Term Radionuclides and Their Transformation in Soils of Chernobyl Area." Soil Science (Pochwovedenie) 10:20-25.

Booth, R. S. 1975. A System Analysis Model for Calculating Radionuclide Transport Between Receiving Water and Bottom Sediments. ORNL-TM-4751, Oak Ridge National Laboratory, Oak Ridge, Tennessee.

Borzilov, V. A., A. V. Konoplev, and S. K. Revina. 1988. "Experimental Study of Wash-out Processes, from Soils after the Chernobyl Accidental Release." Meteorology and Hydrology 11:43-53. (In Russian).

Borzilov, V. A., Yu. S. Sedunov, M. A. Novitsky, O. I. Vozgennikov, and A. K. Gerasimenko. 1989. "Forecasting of Secondary Radioactive Contamination of the Rivers in 30 Kilometers Zone of the Chernobyl NPP." Meteorologya i Gidrologya, N2:5-13. (In Russian).

Bulgakov, A. A., A. V. Konoplev, V. E. Popov, Ts. I. Bobovnikova, A. A. Siverina, and I. G. Shkuratova. 1990. "The Role of Different Vertical Migration Mechanisms of Long-lived Radionuclides in Vadose Soil Zone of 30-km Zone of Chernobyl NPP." Pochwovedenie 10:14-19. (In Russian).

Bulgakov, A. A., A. V. Konoplev, V. E. Popov, and A. V. Scherbak. 1990. "Dynamics of Long-Lived Radionuclide Washout from Soil by Surface Runoff in Chernobyl NPP Region." Pochvovedenie N4:47-54. (In Russian).

Codell R. B., K. T. Key, and G. Whelan. 1982. Collection of Mathematical Models for Radionuclide Dispersion in Surface Water and Groundwater. NUREG-0868, U.S. Nuclear Regulatory Commission, Washington, D.C. 
Cunge, J. A., F. M. Holly, and A. Verwey. 1984. Practical Aspects of Computational River Hydraulics. Pitman Publ., London.

Demchenko, R. I., and M. J. Zheleznyak. 1990. "Numerical Modelling of Suspended Sediments Vertical Distribution Above Uneven Bottom." In System Analysis and Methods of Mathematical Modelling in Ecology, pp. 66-72, V. Glushkov Institute of Cybernetics Publ., Kiev. (In Russian).

Demchuk, V. V., O. V. Voitsekhovitch, V. A. Kashparov, and G. V. Laptev. 1991. "Analysis of Chernobyl Fuel Particles and Their Migration Characteristics in Water and Soil." In Proceedings of Commission of European Communities/Radiation Protection on Seminar on Compararive Assessment of the Environmental Impact of Radionuclides Released During Three Major Nuclear Accidents: Kyshtym, Windscale, Chernobyl. Vol. 1 and 2, pp. 493-514. Commission of European Communities, Luxembourg.

International Commission on the Radiological Protection (ICRP). 1990. Recommendations of the International Commission of Radiation Protection. Radiation Protection, ICRP Publication No. 60, Pergamon Press, New York.

International Commission on the Radiological Protection (ICRP). 1977. Recommendations of the International Commission on Radiological Protection. ICRP Publication 26, Pergamon Press, New York.

International Commission on the Radiological Protection (ICRP). 1979. ICRP Publication 30, Part 1, Limits for Intakes of Radionuclides by Workers. Pergamon Press, New York.

Izrael, Y. A. 1988. "Ecological Consequence of Radioactive Environmental Contamination in Chernobyl Areas." Atomic Energy. 64(1):28-40. (In Russian).

Izrael, Y. A., V. A. Petrov, and C. I. Avdushin. 1987. "Radioactive Contamination of the Environment in the Chernobyl Accident Impacted Zone." Meteorology and Hydrology. 2:5-12. (In Russian). 
Karatchev, I. I., and N. V. Tkatchenko. 1993. "Preliminary Modeling Results of Dnieper River Water Contribution Dose Scenario." Paper presented at the International Atomic Energy Agency's Workshop on Validation of Environmental Model Prediction, March 1993, Vienna, Austria.

Konoplev, A. V., O. Hofman, and O. V. Voitsekhovitch. 1993. "Scenario of Wash-out Radionuclides from Watersheds Polluted by Chernobyl Releases." Paper presented to BIOMOVS, Workshop of the International Atomic Energy Agency, September 25-29, 1993, Vienna, Austria.

Konoplev, A. V., A. A. Bulgakov, and I. G. Shkuratova. 1990. "Migration of Certain Radioactive Products in the Soil and Surface Runoff in the Chernobyl NPP Zone." Meteorologiya $i$ Gidrologiya, N6, pp.119-121. (In Russian).

Konoplev, A. V., V. A. Borzilov, Ts. I. Bobovnikova, E. P. Virchenko, V. E. Popov, and I. V. Kutnyakov. 1988. "Distribution of Radionuclides Deposited in the Soil - Water System Following the Chernobyl Accident." Meteorologia $i$ Gidrologiya. 12, pp. 63-74. (In Russian).

Konoplev, A. V., and Ts. I. Bobovnikova. 1990b. "Comparative Analysis of Chemical Forms of Long-lived Radionuclides and Their Migration and Transformation in the Environment Following the Kyshtym and Chernobyl Accidents." In Proceedings of Seminar on Comparative Assessment of the Environmental Impact of Radionuclides Released During Three Major Nuclear Accidents: Kyshtym, Windscale and Chernobyl. (Luxembourg, 1-5 October 1990), Vol. 1, pp. 371-396. Commission of European Communities, Brussels, Belgium.

Konoplev, A. V., A. Rodhe, and O. V. Voitsekhovitch. 1992. "Chapter 4 - Migration of Contaminant in Water Bodies." In Hydrological Aspects of Accidental Pollution of Water Bodies. WHO No. 754, Operational Hydrology Report No. 37, World Meteorological Organization, Geneva, Switzerland. pp. 27-48. 
Mikhalevich, V. S., A. A. Morozov, M. J. Zheleznyak, and V. M. Mikhailov. 1987. "Mathematical Modelling of the Impacts on Water Quality in the River/Reservoir System." In Problems of Computational and Applied Mathematics, pp. 134-135. Computer Center of the Academy of Science, Novosibirsk, Russia. (In Russian).

Napier, B. A., R. A. Peloquin, and D. L. Strenge. 1988. GENII - The Hanford Environmental Dosimetry Software System. PNL-65854, Vol. 1-3, Pacific Northwest Laboratory, Richland, Washington.

Onishi, Y. 1981. "Sediment and Contaminant Transport Model." Journal of Hydraulics Division, American Society of Civil Engineers, September 1981, 107(HY9):1089-1107.

Onishi, Y., J. Serne, E. Arnold, C. Cowan, and F. Thompson. 1981. Critical Review: Radionuclide Transport, Sediment Transport, Water Quality, Mathematical Modeling and Radionuclide Adsorption/ Desorption Mechanism. NUREG/CR-1322, Pacific Northwest Laboratory, Richland, Washington.

Onishi, Y., S. B. Yabusaki, and C. T. Kincaid. 1982. "Performance Testing of SedimentContaminant Transport Model, SERATRA." In Proceedings of the ASCE Hydraulics Conference, Applying Research to Hydraulic Practice, edited by P. E. Smith, published by ASCE, August 1982.

Onishi, Y., G. Whelan, and R. L. Skaggs. 1982. Development of a Multi-Media Radionuclide Exposure Assessment Methodology for Low-Level Waste Management. PNL-3370, Pacific Northwest Laboratory, Richland, Washington.

Onishi, Y., and D. S. Trent. 1985. "Three-Dimensional St. nulation of Flow, Salinity, Sediment, Radionuclide Movements in the Hudson River Estuary." In Pinceedings of the 1985 Specialty Conference of the Hydraulics Division, American Society of Civ il Engineers, pp. 1095-1100, August 12-17, 1985, Lake Buena Vista, Florida. 
Onishi, Y., and F. L. Thompson. 1986. "Sediment and Contaminant Transport in a Marine Environment." In Proceedings of the Third International Symposium on River Sedimentation, edited by S. Y. Wang, H. W. Shen, and L. Z. Ding, pp. 569-577, March 31-April 4, 1986, Jackson, Mississippi.

Onishi, Y., H. C. Graber, and D. S. Trent. 1993. "Preliminary Modeling of Wave-Enhanced Sediment and Contaminant Transport in New Bedford Harbor." In Book Series 42, of Estuarine and Coastal Water Cohesive Sediment Transport, ed. A. J. Mehta, pp. 541-557, American Geophysical Union, Washington, D.C.

Onishi, Y., G. M. Petrie, L. W. Vail, O. V. Voitsekhovitch, M. J. Zheleznyak, V. M. Shershakov, and A. V. Konoplov. 1993. "USA/CIS Coordinating Committee and Its Hydrologic Studies." In Proceedings of the United National UNESCO Wbrkshop on Hydrological Impact of Nuclear Power Plant System, September 23-25, 1992, Paris, France, UNESCO Press, Paris.

Prister, B., N. Loschilov, L. Perepelyatnicova, and G. Perepelyatnicov. 1992. "Efficiency of Measures Aimed at Decreasing the Contamination of Agricultural Products in Areas Contaminated by the Chernobyl NPP Accident." The Science of the Total Environment, 112 p. 79-87.

Repin, V. G., and V. D. Berkovsky. 1992. Dose/Risk Assessment for Population Living Along Dnieper Cascade Due to Water Consumption and Connected with That Risk for Human Health. Institute of Radiation Medicine, Kiev. (In Russian).

Ryabov, I. N. 1990. "Estimation of Impact of Radioactive Contamination Upon Hydrobionts in the $30 \mathrm{~km}$ Zone of Chernobyl." In Seminar on Comparative Assessment of the Environmental Impact of Radionuclides Released During Three Major Nuclear Accidents: Kyshtym, Windscale, Chernobyl, Luxembourg, 1-5 October, 1990. Commission of European Communities, Brussels, Belgium.

Santschi, P. H., and B. D. Honeyman. 1989. "Radionuclides in Aquatic Environments." Radiation Phys. Chem. 34(N2):213-240. 
Schuckler, M., R. Kalckbrenner, and A. Bayer. 1976. "Zukunftige Radiologische Belastung durch Kerntechnische Anlagen im Einzugsgebiet des Oberrheins, T.2, Belastung uber den Wasserweg." In Proceedings of the Conference, Dusseldorf, ZAED, Eggenstein-Leopoldshafen.

Vakulovsky, S., A. Nikitin, V. Chumitchov, and O. Voitsekhovitch. 1991. "The Cs and Sr Water Bodies Contamination, Due to Chernobyl Accidental Realize." J. Meteorology Hydrology 7:64-73. (In Russian).

Vakulovsky, S. M., and O. V. Voitsekhovitch. 1990. "Radioactive Contamination of Water Bodies in the Area Affected by Releases from the Chernobyl Nuclear Power Plant Accident." In Proceedings of IAEA Symposium, Vienna, 16-20 October, 1989. Environmental Contamination Following a Major Nuclear Accident, pp. 231-246. International Atomic Energy Agency, Vienna, Austria.

Vakulovsky, S. M., A. I. Nikitin, V. B. Chumichev, I. Y. Katrich, O. A. Voitsekhovitch, V. I. Medinets, Y. S. Tsaturov, and E. S. Khersonsky. 1993. "Organization of a System for Monitoring Radioactive Contamination of Water Bodies in Belarus, Russia and Ukraine after the Chernobyl Nuclear Power Plant Accident and the Results Obtained for Cesium-137 and Strontium-90 Contamination of Natural Waters." In Proceedings of UNESCO Wbrkshop on Hydrological Impact of Nuclear Power Plant System. September 23-25, 1992. UNESCO Press, Paris. pp. 296-309.

Voitsekhovitch, O. V., V. V. Kanivets, and A. J. Shereshevsky. 1989. "The Estimation of Effectiveness to Catch of the Polluted Suspended Sediments by the Created Rivers Channel Traps." Proc. UHMI, 228:60-68. (In Russian).

Voitsekhovitch, O. V., V. V. Demchuk, and G. V. Laptev. 1990. "Analysis of Secondary Processes of Pripyat River Contamination Following Floodplain Area Flooding Near Chernobyl Close-in Zone." In Proceedings of the Ukrainian Hydrometeorological Institute, 240:54-67. (In Russian). 
Voitsekhovitch, O. V., V. A. Borzilov, and A. V. Konoplyov. 1991. "Hydrological Aspects of Radionuclide Migration in Water Bodies Following the Chernobyl Accident." In Proceedings of Seminar on Comparative Assessment of the Environmental Impact of Radionuclides Released During Three Major Nuclear Accidents: Kyshtym, Windscale, Chernobyl, Luxembourg, October 1-5, 1990, Vol.2, p. 528-548. Commission of the European immunities, Radiation Protection - 53, Brussels, Belgium.

Voitsekhovitch, O. V., V. V. Kanivets, G. V. Laptev, and I. Y. Biley. 1993a. "Hydrological Processes and Their Influence on Radionuclide Behavior and Transport by Surface Water. Pathways as Applied to Water Protection after Chernobyl Accident." In Proceedings of UNESCO Wrkshop on Hydrological Impact of Nuclear Power Plant System. September 23-25, 1992. UNESCO Press, Paris. pp. 83-105.

Voitsekhovitch, O. V., V. V. Kanivets, and G. V. Laptev. 1993b. "The Analysis of the Processes on the Radionuclide Contamination Formation for Dnieper Aquatic System After the Chernobyl Events." In Proceedings of the Ukrainian Hydrometeorological Institute, 245:106-135. (In Russian).

Zheleznyak, M. J., R. I. Demchenko, S. L. Khursin, Yu. I Kuzmenko, P. V. Tkalich, and N. Ya. Vitjuk. 1992a. "Mathematical Modeling of Radionuclide Dispersion in the Pripyat-Dnieper Aquatic System after the Chernobyl Accident." The Science of the Total Environment 112:89-114.

Zheleznyak, M. J., O. V. Voitsekhovitch, R. I. Demchenko, Yu. I. Kuzmenko, P. V. Tkalich, and S. L. Khursin. 1992b. "Simulating the Effectiveness of Measures to Reduce the Transport of Radionuclides in the Pripyat-Dnieper." In Proceedings of the Internal Symposium on Intervention Levels and Countermeasures for Nuclear Accidents. Cadarashe, France, October 7-11, 1991. pp. 336-362. Commission of European Communities, Brussels, Belgium. 
Zheleznyak, M. J., R. I. Demtchenko, Yu. I. Kuzmenko, P. V. Tkalich, N. N. Dzuba, and I. V. Mezhueva. 1993. "Mathematical Modelling of Radionuclide Dispersion in the Water Bodies of the Chernobyl NPP Zone and in the Dnieper Reservoirs." In Proceedings of UNESCO Wbrkshop on Hydrological Impact of Nuclear Power Plants September 23-25, 1992, Paris, France, pp. 173-185. UNESCO Press, Paris.

Zheleznyak, M. J., and O. V. Voitsekhovitch. 1991. "Mathematical Modelling of Radionuclide Dispersion in Surface Waters after the Chernobyl Accident to Evaluate the Effectiveness of Water Protection Measures." In Proceedings of Seminar on Comparative Assessment of the Environmental Impact of Radionuclides Released During Three Major Nuclear Accidents: Kyshtym, Windscale, Chernobyl. Luxembourg, October 1-5, 1990, Vbl.2, pp. 725-748. Radiation Protection-53, EUR 13574, Commission of European Communities, Brussels, Belgium.

Zheleznyak, M. J. 1990. "Mathematical Models of Radionuclide Dispersion in a Reservoir Set." In System Analysis and Methods of Mathematical Modelling in Ecology, pp. 448-58. V. Glushkov Institute of Cybernetics, Kiev, Ukraine. (In Russian). 
Appendix

Equations of the Box Model WATOX

1 


\section{Appendix}

\section{Equations of the Box Model WATOX}

For modeling, the Dnieper River reservoir system was considered be made up of a set of fully mixed compartments (boxes). The box model used for this study describes temporal dynamics of water volume $V_{i}(t)$ and compartmentally averaged concentrations of suspended sediments $S_{i}(t)$ and radionuclides in water $C_{i}(t)$, on suspended sediments $C_{i}^{s}(t)$, and in the active upper layer of the bottom deposition $C_{i}^{b}(t)$ for each compartment.

The water-balance equation for the set of the compartments is

$$
\frac{d V_{i}}{d t}=Q_{i-1}-Q_{i}+R_{i}-Q_{i}^{W}+\sum_{j=1}^{m_{i}} Q_{j}^{t}
$$

$$
\text { where } \begin{aligned}
m_{i} & =\text { number of tributaries } \\
Q_{i-1} & =\text { water discharge into compartment } i \\
Q_{i} & =\text { discharge from compartment } i \\
Q_{j}^{t} & =\text { discharges from tributary } j \text { to compartment } i \\
Q_{i}^{w} & =\text { total water intake (e.g., drinking and irrigation water intakes) from compartment } i \\
R_{i} & =\text { difference between precipitation and evaporation rates. } \\
t & =\text { time. }
\end{aligned}
$$

Transport equations for the bux model were derived by integration from the transport equation of the two-dimensional lateral-longitudinal model over the surface-water body (Onishi 1981; Zheleznyak 
et al. 1992c, 1993). Integrating the two-dimensional suspended sediments transport equation from the COASTOX model (Zheleznyak et al. 1992c, 1993) with appropriate conditions yields

$$
\frac{d\left(V_{i} S_{i}\right)}{d t}=Q_{i-1} S_{i-1}-Q_{i} S_{i}+q_{i}^{b}-q_{i}^{S}+R_{i}^{h}-S_{i} Q_{i}^{w}+\sum_{j=1}^{m_{i}} Q_{j}^{t} S_{j}^{t}
$$

where $S_{1}=$ compartmentally averaged suspended sediment concentration

$S_{i-1}=$ suspended sediment concentration in inflow from compartment $i$

$\mathbf{R}^{\mathrm{h}}=$ sediment flux into the compartment due to overland and coastal erosion processes

$$
S_{j}^{t}=\text { sediment concentration of tributary } j
$$

$q_{i}^{b}$ and $q_{i}^{s}=$ compartmentally integrated rates of sediment resuspension and sedimentation, respectively. These rates are calculated as follows:

$$
\begin{aligned}
& q_{i}^{s}=\left\{\begin{array}{cc}
F_{i} W_{0}\left(S_{i}-S_{i}^{*}\right) & S_{i}>S_{i}^{*} \\
0 & S_{i}<S_{i}^{*}
\end{array}\right. \\
& q_{i}^{b}=\left\{\begin{array}{cc}
0 & S_{i}>S_{i}^{*} \\
F_{i} W_{0}\left(S_{i}^{*}-S_{i}\right) & S_{i}<S_{i}^{*}
\end{array}\right.
\end{aligned}
$$

where $S_{i}^{*}=$ the near-bottom equilibrium sediment concentration that corresponds to the sediment capacity for steady uniform flow with the same local parameters

$$
\begin{gathered}
F_{i}=\text { the bottom surface area } \\
W_{0}=\text { sediment fall velocity. }
\end{gathered}
$$

The value of $F_{i}$ is defined by the Bijker method through the compartmentally averaged current velocity $\mathrm{U}_{i}=\mathrm{Q}_{\mathrm{i}} \mathrm{L}_{\mathrm{i}} / \mathrm{V}_{\mathrm{i}}$, where $\mathrm{L}_{\mathrm{i}}$ is compartment length.

The temporal dynamic of the mass of the contaminated bottom sediment, $M_{i}^{b}$, is 


$$
\begin{gathered}
\frac{d M_{i}^{b}}{d t}=q_{i}^{s}-q_{i}^{b} \\
M_{i}^{b}=\rho_{s}(1-\epsilon) Z_{*} F_{i}
\end{gathered}
$$

where $Z_{*}=$ the effective bed thickness

$$
\begin{aligned}
\rho_{\mathrm{s}} & =\text { bottom sediment density } \\
\epsilon & =\text { porosity. }
\end{aligned}
$$

The radionuclide transport equations describe advective transport of solutes and with sediments, as well as radionuclide exchange processes between water (phase 1), suspended sediments (phase 2), and bottom sediments (phase 3). Radionuclide-sediment interactions resulting from physical-chemical exchange between phases and sedimentation-resuspension processes are also considered, as described by Onishi et al. (1982). The adsorption/desorption process is simulated by a sorption-adsorption submodel using the transfer rate coefficients $A_{i j}$ and the distribution coefficient $K_{d}$ as the main parameters of the processes. A second submodel is governed by sedimentation and resuspension fluxes, whose rates $q_{i}^{b}$ and $q_{i}^{s}$ were determined in Equations (3) and (4).

The model equations based on the mass conservation and the interaction models are written as follows:

$$
\begin{aligned}
\frac{d\left(V_{i} C_{i}\right)}{d t}= & Q_{i-1} C_{i-1}-Q_{i} C_{i}-A_{1,2}\left(K_{d} C_{i}-C_{i}^{s}\right) \\
& -A_{1,3}\left(K_{d} C_{i}-C_{i}^{b}\right)-\lambda V_{i} C_{i}+\sum_{j=1}^{m} Q_{j}^{t} C_{j}^{t}
\end{aligned}
$$




$$
\begin{aligned}
\frac{d\left(V_{i} S_{i} C_{i}^{s}\right)}{d t}= & Q_{i-1} S_{i-1} C_{i-1}^{s}-Q_{i} S_{i} C_{i}^{s}+A_{1,2}\left(K_{d} C_{i}-C_{i}^{s}\right) \\
& +C_{i}^{b} q_{i}^{b}-C_{i}^{s} q_{i}^{s}-Q_{i}^{w} C_{i}^{s} S_{i}+R_{i}^{h} C_{i}^{h}-\lambda V_{i} S_{i} C_{i}^{s}+\sum_{j=1}^{m} Q_{j}^{t} S_{j}^{t} C_{j}^{s t}
\end{aligned}
$$

where $A_{1,2}=$ radionuclide transfer rate between water and suspended sediment

$A_{1,3}=$ radionuclide transfer rate between water and bed sediment.

$$
\frac{d\left(M_{i}^{b} C_{i}^{b}\right)}{d t}=C_{i}^{s} q_{i}^{s}-C_{i}^{b} q_{i}^{b}+A_{1,3}\left(K_{d} C_{i}-C_{i}^{b}\right)-\lambda M_{i} C_{i}
$$

where $\mathrm{C}_{\mathbf{i}}=$ radionuclide

$C_{i}^{k}=$ radionuclide concentration associated with suspended sediment in compartment $i$

$C_{i}^{b}=$ radionuclide concentration associated with bed sediment in compartment $i$

$\mathrm{C}_{\mathrm{j}}^{\mathrm{t}}=$ concentration in tributary $\mathbf{j}$

$C_{j}^{\mathrm{kt}}=$ suspended-sediment-solved radionuclide concentrations in tributary $\mathrm{j}$

$C_{i}^{h}=$ radionuclide concentration associated with sediments discharged into compartment $i$ due to overland and coastal erosion

$\lambda=$ radionuclide decay rate.

The exchange rate coefficients in this model may be written

$$
\begin{aligned}
& A_{1,2}=\frac{V_{i} S_{i}}{1+K_{d} S_{i}}\left[\frac{\delta_{1,2}}{t_{s}}+\frac{\delta_{2,1}}{t_{d s}}\right] \\
& A_{1,3}=\frac{M_{i}^{b}}{1+K_{d} \frac{M_{i}^{b}}{V_{i}}}\left[\frac{\delta_{1,3}}{t_{s b}}+\frac{\delta_{3,1}}{t_{d s b}}\right]
\end{aligned}
$$

where $t_{s}$ and $t_{d s}=$ the time scale of the adsorption and desorption processes, respectively, for the water-suspended sediments system 


$$
\begin{aligned}
t_{s b}, t_{d s b}= & \text { the time-scale of the adsorption and desorption process, respectively, for the } \\
& \text { water-bottom sediment system. } \delta_{1, p} \text { and } \delta_{p, 1} \text { determine the direction of the } \\
& \text { contamination transfer and can be written }
\end{aligned}
$$

$$
\begin{aligned}
& \underset{\mathrm{p} \pm 1}{\delta_{1, p}}= \begin{cases}1 & \mathrm{~K}_{\mathrm{d}} \mathrm{C}_{\mathrm{i}}^{1}>\mathrm{C}_{\mathrm{i}}^{\mathrm{p}} \\
0 & \mathrm{~K}_{\mathrm{d}} \mathrm{C}_{\mathrm{i}}^{1}<\mathrm{C}_{\mathrm{i}}^{\mathrm{p}}\end{cases} \\
& \underset{\mathrm{p} \pm 1}{\delta_{\mathrm{p}, 1}}= \begin{cases}1 & \mathrm{~K}_{\mathrm{d}} \mathrm{C}_{\mathrm{i}}^{1}<\mathrm{C}_{\mathrm{i}}^{\mathrm{p}} \\
0 & \mathrm{~K}_{\mathrm{d}} \mathrm{C}_{\mathrm{i}}^{1}>\mathrm{C}_{\mathrm{i}}^{\mathrm{p}}\end{cases}
\end{aligned}
$$

Note that $C_{i}$ is used for $p=1, C_{i}^{s}$ for $p=2$, and $C_{i}^{b}$ for $p=3$.

Equations (2) and (5)-(7) can be transformed to more appropriate forms for numerical solution by taking into account the equations of water and bottom sediment mass conservation, (1) and (4). Substituting them into these equations yields the following governing equations:

$$
\begin{aligned}
\frac{d S_{i}}{d t}=\frac{1}{V_{i}}\left[Q_{i-1} S_{i-1}-Q_{*} S_{i}+q_{i}^{b}-q_{i}^{s}+R_{i}^{h}+\sum_{j=1}^{m} Q_{j}^{t} S_{j}^{t}\right] & \\
\frac{d C_{i}}{d t}= & -\left[\lambda+\frac{Q_{*}}{V_{i}}+\frac{K_{d}}{V_{i}}\left(A_{1,2}+A_{1,3}\right)\right] C_{i} \\
& +\frac{1}{V_{i}}\left[\sum_{j=1}^{m_{i}} Q_{j}^{t} C_{j}^{t}+Q_{i-1} C_{i-1}+A_{1,2} C_{1}^{s}+A_{1,3} C_{i}^{b}\right] \\
\frac{d C_{i}^{s}}{d t}=\frac{1}{V_{i} S_{i}}\{ & {\left[A_{1,2}+K_{i}^{h}+q_{i}^{b}+Q_{i-1} S_{i-1}+\sum_{j=1}^{m}\left(Q_{j} S_{j}\right)+\lambda V_{i} S_{i}\right] C_{i}^{s} } \\
+ & \left.Q_{i-1} S_{i-1} C_{i-1}^{s}+R_{i}^{h} C_{i}^{h}+q_{i}^{b} C_{i}^{b}+\sum_{j=1}^{m} Q_{j}^{t} S_{j}^{t} C_{j}^{s t}+A_{1,2} K_{d} C_{i}\right\}
\end{aligned}
$$




$$
\frac{d C_{i}^{b}}{d t}=\frac{1}{M_{i}^{b}}\left[-\left(A_{1,3}+q_{i}^{s}+\lambda M_{i}^{b}\right) C_{i}^{b}+q_{i}^{s} C_{i}^{s}+A_{1,3} K_{d} C_{i}\right]
$$

where $Q_{*}=Q_{i-1}+R_{i}+\sum_{j=1}^{m} Q_{j}^{t}$

The radionuclide transport submodel contains six constants: $\lambda, K_{d}, t_{3}, t_{d s}, t_{s b}$, and $t_{d s b}$. The number of model constants can be reduced if the reversibility of the adsorption-desorption processes is considered, i.e., $t_{s}=t_{s b}, t_{d s}=t_{d s b}$.

The computer system WATOX includes a numerical procedure to solve equations (1) and (10)-(13). In the simulations for this study, WATOX used the 10-day-averaged hydrological and radiological data for the Dnieper reservoir system. 


\section{Distribution}

No. of

Copies

\section{OFFSITE}

12 DOE/Office of Scientific and Technical Information

L. R. Anspaugh

Risk Assessment Center

Health and Ecological Assessment

Division

Geoscience and Environmental Research

Program

Physical Sciences Directorate

Lawrence Li , ermore National Laboratory

P.O. Box 808

Livermore, CA 94550

B. G. Blaylock

Environmental Sciences Division

Oak Ridge National Laboratory

P.O. Box 2008

Oak Ridge, TN 37831-6250

M. Hanif Chaudhry

Department of Civil and Environmental

Engineering

Washington State University

Pullman, WA 99164

J. A. Cochran, Dean

Washington State University at Tri-Cities

Richland, WA 99352

R. B. Cook

Environmental Sciences Division

$y$

Oak Ridge National Laboratory

P.O. Box 2008

Oak Ridge, TN 37831-6250
No. of

Copies

\section{OFFSITE}

D. Cool, Chief

Radiation Protection and Health Effects

Branch

Office of Research

U.S. Nuclear Regulatory Commission

Washington, D.C. 20555

W. R. Curtis

Oceans Program

Office of Radiation Programs

U.S. Environmental Protection Agency

401 M Street SW

Washington, D.C. 20460

A. S. Donigian, President Aqua Terra Consultants

2672 Bayshore Frontage Road

Suite 1001

Mountain View, CA 94043-1011

L. Duhon

SABIT Office, Room 3413

International Trade and Administration

U.S. Department of Commerce

14 St. Constitution Ave., N.W.

Washington, D.C. 20230

G. Dunbar, Executive Vice President

Los Alamos Technical Associates

11 Old Whars Road

West Newberry, MA 01985

R. Dyer

Office of Radiation Program

U.S. Environmental Protection Agency

401 M Street SW

Washington, D.C. 20460 
No. of

Copies

OFFSITE

S. S. Fan

Hydropower Licensing Division

Federal Energy Regulatory Commission

Room 5048, Bldg. 810

Washington, D.C. 20426

C. W. Frank

Deputy Assistant Secretary for Technology

Development

Office of Environmental Management

U.S. Department of Energy

Washington, D.C. 20585

M. Goldman, Professor of Radiobiology

Laboratory for Energy-Related Health

Research

University of California, Davis

Davis, CA 95616

R. Goldsmith, Director EH-42

Office of Epidemiology and Health

Surveillance

J-106/GTN

U.S. Department of Energy

Washington, D.C. 20874

S. Hendrickson

Risk Assessment Center

Health and Ecological Assessment

Division

Geoscience and Environmental Research

Program

Physical Sciences Directorate

Lawrence Livermore National Laboratory

P.O. Box 808

Livermore, CA 94550

F. O. Hoffman, Jr., President

Senes Oak Ridge, Inc.

677 Emory Valley Road, Suite C

Oak Ridge, TN 37830
No. of

Copies

\section{OFFSITE}

R. Y. Itani

Department of Civil and Environmental Engineering

Washington State University

Pullman, WA 99162

G. H. Jirka

Ralph M. Parsons Laboratory

Department of Civil Engineering

Massachusetts Institute of Technology

Cambridge, MA 02139

K. Kim

H. Krumb School of Mines

809 Seely W. Mudd

Columbia University

New York, NY 10027

J. Koehler

Innovative Technology Council

Office of International Activities

Mail Code 2631

U.S. Environmental Protection Agency

401 M Street, SW

Washington, D.C. $20+60$

R. B. Krone

Department of Civil and Environmental Engineering

University of California, Davis

Davis, CA 95616-5294

E. R. Landa

U.S. Geological Survey

431 National Center

Reston, VA 22092

S. C. T. Lien, Director EM-54 Office of Research and Development Office of Technology Development Office of Environmental Management U.S. Department of Energy

Washington, D.C. 20585 
No. of

Copies

\section{OFFSITE}

W. J. Madia

Environmental Systems and Technology

Division

Battelle Memorial Institute

505 King Avenue

Columbus, OH 43201-2.693

C. W. Miller

Radiation Studies Branch

Centers of Disease Control and Prevention MS-F35

4770 Buford Highway NE

Atlanta, GA 30341-3724

\section{J. Modzelewski}

OCEE, FO-2014

National Academy of Sciences

2101 Constitution Avenue

Washington, D.C. 20418

\section{J. F. Paul}

Environmental Research Laboratory

U.S. Environmental Protection Agency

Narragansett, RI 02882

H. J. Pettengill, EH-40

Deputy Assistant Secretary for Health

G-165/GTN

U.S. Department of Energy

Washington, D.C. 20874

D. Robey

Environmental Laboratory

Waterways Experimental Station

U.S. Army Corps of Engineers

Vicksburg, MS 39180

\section{T. Sanders}

Sandia National Laboratory

Mail Stop 6323

P.O. Box 5800

Albuquerque, NM 87185
No. of

Copies

\section{OFESITE}

M. Schulman

Executive Assistant to the Director of

Health and Environmental Research

F-207/GTN

U.S. Department of Energy

Washington, D.C. 20585

E. Shoemaker, Program Manager

U.S. Soviet Exchange Program

White Flint 3 H-5

U.S. Nuclear Regulatory Commission

Washington, D.C. 20555

G. L. Schnoor

Center for Global and Regional

Environmental Research

Department of Civil and Environmental

Engineering

University of Iowa

lowa City, IA 52242

J. E. Till, President

Radiological Assessment Corp.

Rt. 2, Box 122

Neeses, SC 29107

W. A. Thomas

Environmental Laboratory

Waterways Experimental Station

U.S. Army Corps of Engineers

Vicksburg, MS 39180

C. F. Tsang

Earth Sciences Division

Building 50E

Lawrence Berkeley Laboratory

1 Cyclotron Road

Berkeley, CA 94720

M. T. van Genuchten

U.S. Salinity Laboratory

U.S. Department of Agriculture

Riverside CA 92501 
No. of

Copies

\section{OFISITE}

\section{S. S. Y. Wang}

Center for Computational Hydrosciences and Engineering

University of Mississippi

University, MS 38677

E. Washburn

Health Communications and

Coordination Division, EH-422

J-116/GTN

U.S. Department of Energy

Washington, D.C. 20585

P. A. Witherspoon

427 Hearst Mining Bldg.

University of California

Berkeley, CA 94720

K. W. Yeh

Office of Radiation Program

U.S. Environmental Protection Agency

401 M Street SW

Washington, D.C. 20400

C. Yu

Argonne National Laboratory

Building 900

9700 South Cass Avenue

Argonne, IL 60439

\section{FOREIGN}

Y. Akimoto, President

Mitsubishi Materials Corporation

5-1, 1-Chome, Ohtemachi

Chiyoda-ku, Tokyo 100

JAPAN
No. of

Copies

\section{FOREIGN}

\section{P. Appleby}

Department of Applied Mathematics and Theoretical Physics

University of Liverpool

P. O. Box 147

Liverpool L69 3BX

UNITED KINGDOM
A. Aureli
Division of Water Sciences
International Hydrological Programme
United Nations Educational
Scientific and Cultural Organization
1 rue Miollis, 75732
Paris CEDEX 15
FRANCE

\section{J. Brown}

National Radiological Protection Board

Chilton, Didcot

Oxon OX11 ORQ

UNITED KINGDOM

R. N. J. Comans

Netherlands Energy Research Foundation ECN

Soil and Waste Research

P. O. Box 1, 1755 ZG Petten

THE NETHERLANDS

G. Desmet

Radiation Protection Progmamme

Commission of European Communities

Rue de la Loi 200

B-1049 Brussels

BELGIUM

L. Haakanson

Department of Hydrology

University of Uppsala

Vastra Agatan 24

75220 Uppsala

SWEDEN 
No. of

Copies

\section{FOREIGN}

J. Hilton

Institute of Freshwater Ecology

Natural Fnvironmental Research Council

Windermere Laboratory

Ambleside Cumbria LAZZ OLP

UNITED KINGDOM

G. L. Linsley

Nuclear Fuel and Waste Management

Division

International Atomic Energy Agency

Wagramerstrasse 5, P. O. Box 100

A-1400 Vienna

AUSTRIA

A. Maximov

Scientific Secretary

CIS National Committee for the IHP

State Committee for Hydrometeorology

and the Control of Environment

12 Pavliok Morozov Street

123376 Moscow D-376

RUSSIA

K. L. Sjoeblom

Nuclear Fuel and Waste Management

Division

International Atomic Energy Agency

Wagramerstrasse 5, P. O. Box 100

A-1400 Vienna

AUSTRIA

T. Terashima, Commissioner

Nuclear Safety Commission

2-2-1, Kasumigaseki, Chiyoda-ku

Tokyo, 100

JAPAN
No. of

Copies

FOREIGN

H. Tasaka

Integrated Research Division

The Japan Research Institute, Limited

Kioicho Bldg., 3-12, Kioicho, Chiyoda-ku

Tokyo, 102

JAPAN

10 O. V. Voitsekhovitch

Ukrainian Institute of Hydrometeorology

Nauka Avenue, 37

$252028 \mathrm{Kiev}$

UKRAINE

O. A. Volkavitsky, Director

Scientific Production Association

TYPHOON

82, Lenin Street

Obninsk, Kaluga Region

249020

RUSSIA

10 M. J. Zheleznayk

Institute of Mathematical Machines and

Systems

Cybernetics Centers

Ukrainian Academy of Sciences

Prospect Academica Glushkova, 20

$252207 \mathrm{Kiev}$

UKRAINE

\section{QNSITE}

2 DOE, Richland Operations Office

D. D. Green

K8-50

R. A. Holten

A5-55

3 Westinghouse Hanford Company

G. R. Bopp

B5-32

M. C. Hagood

H6-01

J. D. Hoover 
No. of

Copies

ONSITE

65 Pacific Northwest Laboratory

J. F. Bagley

K1-66

E. M. Baroni

M. P. Bergeron

D. J. Bradley

L. R. Dodd

D. W. Dragnich

M. D. Freshley

M. L. Knotek

B. A. Napier

Y. Onishi (40)

G. M. Petrie

R. G. Schreckhise

D. B. Shipler

S. C. Slate

S. L. Stein

K6-77

K8-41

K8-31

BWO

K6-77

K1-48

K3-54

K6-77

K6-85

H2-52

B1-34

K1-19

BSRC
No. of

Copies

\section{ONSITE}

W. L. Templeton

B1-34

L. W. Vail

K6-77

D. E. Wester

W. R. Wiley

Publishing Coordination

P7-25

K1-46
Technical Report Files (5)

\section{Routing}

R. M. Ecker

R. W. Forester

M. J. Graham

P. M. Irving

C. S. Sloane

S. L. Van Erem

P. C. Hays/L. K. Grove (last)
K6-88

K6-78

K6-98

K6-04

K6-88

K6-86
SEQUIM 

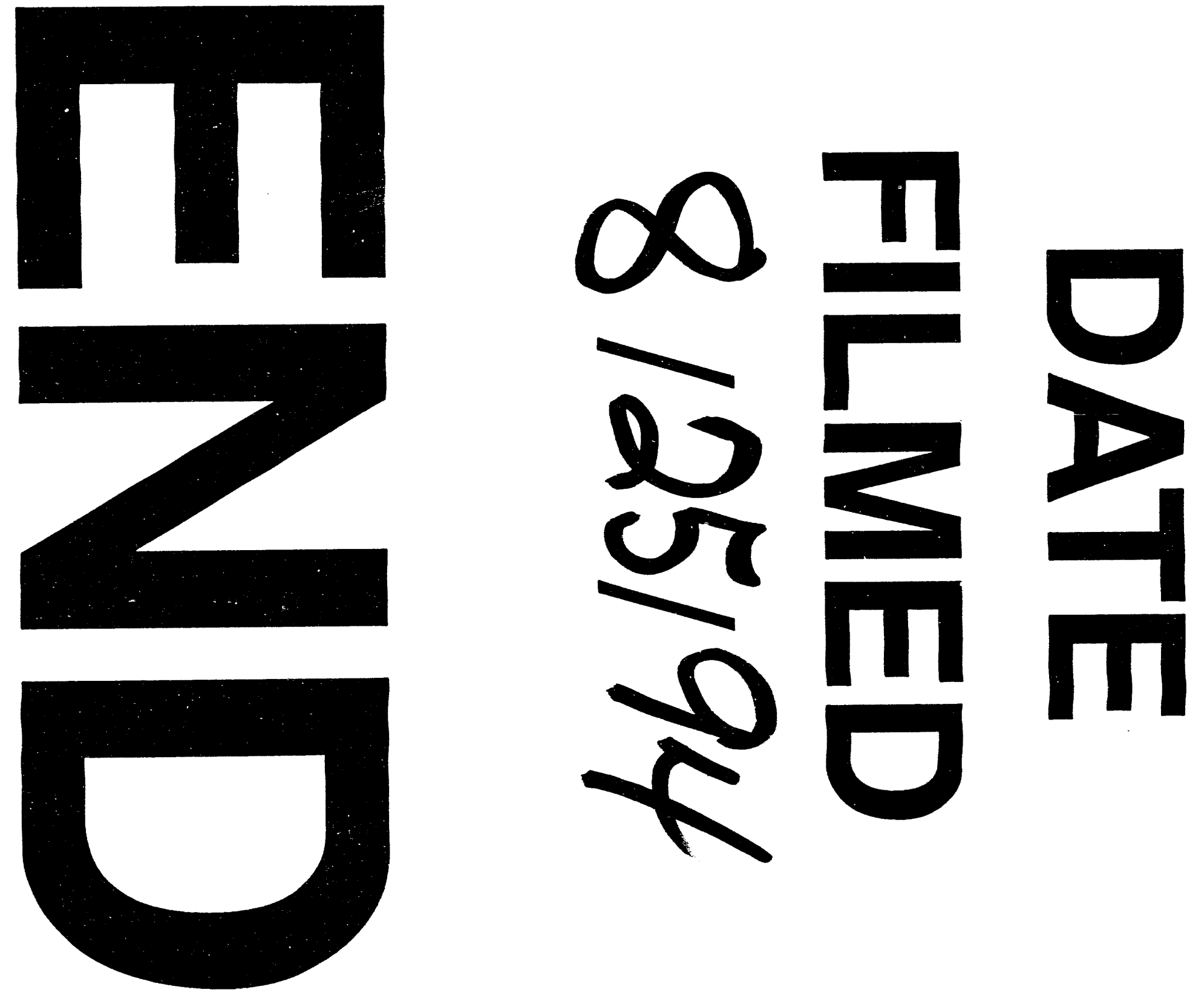